\title{
A review of natural aerosol interactions and feedbacks within the Earth system
}

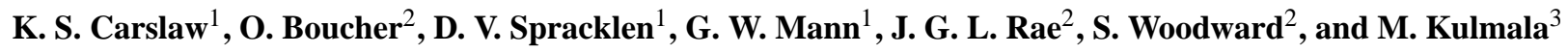 \\ ${ }^{1}$ School of Earth and Environment, University of Leeds, Leeds, UK \\ ${ }^{2}$ Met Office Hadley Centre, FitzRoy Road, Exeter, UK \\ ${ }^{3}$ University of Helsinki, Department of Physics, Division of Atmospheric Sciences and Geophysics, Helsinki, Finland
}

Received: 7 April 2009 - Published in Atmos. Chem. Phys. Discuss.: 5 May 2009

Revised: 11 December 2009 - Accepted: 18 January 2010 - Published: 15 February 2010

\begin{abstract}
The natural environment is a major source of atmospheric aerosols, including dust, secondary organic material from terrestrial biogenic emissions, carbonaceous particles from wildfires, and sulphate from marine phytoplankton dimethyl sulphide emissions. These aerosols also have a significant effect on many components of the Earth system such as the atmospheric radiative balance and photosynthetically available radiation entering the biosphere, the supply of nutrients to the ocean, and the albedo of snow and ice. The physical and biological systems that produce these aerosols can be highly susceptible to modification due to climate change so there is the potential for important climate feedbacks. We review the impact of these natural systems on atmospheric aerosol based on observations and models, including the potential for long term changes in emissions and the feedbacks on climate. The number of drivers of change is very large and the various systems are strongly coupled. There have therefore been very few studies that integrate the various effects to estimate climate feedback factors. Nevertheless, available observations and model studies suggest that the regional radiative perturbations are potentially several Watts per square metre due to changes in these natural aerosol emissions in a future climate. Taking into account only the direct radiative effect of changes in the atmospheric burden of natural aerosols, and neglecting potentially large effects on other parts of the Earth system, a global mean radiative perturbation approaching $1 \mathrm{~W} \mathrm{~m}^{-2}$ is possible by the end of the century. The level of scientific understanding of the climate drivers, interactions and impacts is very low.
\end{abstract}

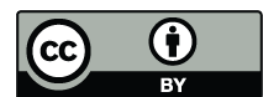

Correspondence to: K. S. Carslaw (k.s.carslaw@leeds.ac.uk)

\section{Introduction}

Aerosols are important components of most parts of the Earth system. In the atmosphere, they affect the radiative balance by scattering and absorbing radiation and affecting the properties of clouds (Haywood and Boucher, 2000; Lohmann and Feichter, 2005; Forster et al., 2007). In the cryosphere, deposition of light absorbing carbonaceous and dust particles on ice and snow impacts the surface albedo and absorption of solar radiation (Warren and Wiscombe, 1980; Krinner et al., 2006), leading to modification of the snow/ice-albedo feedback mechanism (Flanner et al., 2007). The terrestrial biosphere is a major source of primary aerosol and aerosol precursor gases that form secondary organic aerosol (SOA), and the net primary productivity of plants can be influenced by the effect of aerosol on diffuse radiation (Gu et al., 2003; Mercado et al., 2009). A large fraction of atmospheric dust is natural and such emissions may have large increases (Woodward et al., 2005) or decreases (Mahowald et al., 2003, 2006) in a future climate, responding strongly to simulated vegetation changes. The oceans emit aerosol precursor gases such as dimethylsulphide (DMS) and primary sea spray particles, and marine biota are supplied with nutrients from aerosol deposition, particularly dust, which can impact the carbon cycle.

The terrestrial biosphere, land surface and oceans make a very large and temporally variable contribution to global atmospheric aerosol and cloud condensation nuclei (Andreae and Rosenfeld, 2008). For example, observations from around the world suggest that in many places more than half of the sub-micron aerosol mass is organic (Zhang et al., 2007a) and is dominated by compounds of biogenic origin (Hallquist et al., 2009). Likewise, model studies suggest that the oceanic emission of dimethylsulphide from plankton accounts for between 18 and $42 \%$ of the global atmospheric sulphate aerosol mass (Chin and Jacob, 1996; Gondwe et al.,

Published by Copernicus Publications on behalf of the European Geosciences Union. 
2003; Kloster et al., 2006). There is therefore the potential for substantial long term changes in the atmospheric aerosol burden and climate feedbacks if the processes that drive the emissions are perturbed by climate change.

Natural aerosol sources vary substantially with climate on seasonal, interannual and decadal timescales. For example, wildfire aerosol emissions have an interannual variation of more than a factor of 2 driven partly by internal climate variability such as El Niño (Schultz et al., 2008), and decadal climate change seems to be affecting the occurrence of forest fires in some regions (Gillett et al., 2004; Westerling et al., 2006; Flannigan et al., 2009). In the boreal forest, particle growth rates correlate with seasonal variations in vegetation gross primary productivity, most likely due to varying emissions of terpenes that form SOA (Kulmala et al., 2004a), and interannual variations in temperature probably control large changes in biogenic isoprene (Palmer et al., 2006). There is evidence from ice cores that a tracer of marine DMS emissions varies on decadal and centennial timescales (Legrand, 1997), while seasonal variations in DMS from plankton in the Southern Ocean (Ayers and Gras, 1991; Ayers et al., 1997; Sciare et al., 2000a, b) appear to drive substantial changes in sulphate aerosol mass and cloud properties (Boers et al., 1994). Atmospheric dust is also changing partly due to climate effects. For example, dust concentrations at Barbados show a four-fold increase since the 1960s driven by meteorological changes in the African source region (Prospero and Lamb, 2003).

In addition to direct observational evidence for the effects of climate on natural aerosol emissions, process studies strongly suggest that large climatic effects can be expected. For example, the vegetation emissions of many terpene species that form SOA in the atmosphere are affected by temperature, radiation, soil moisture, foliar biomass, atmospheric composition, and vegetation type (Guenther et al., 1995, 2006), all of which are likely to change with climate. Likewise, the occurrence of forest fires is clearly related to temperature and hydrology (Westerling et al., 2006) and dust emissions to vegetation, soil wetness and wind speed, among other variables.

This review describes the response of these natural atmospheric aerosols to climate and environmental change on the century timescale. The climate drivers of changes in aerosol can be split broadly into physical changes (temperature, soil wetness, solar radiation, wind speed, sea ice extent, etc.) and biological changes (vegetation, plankton, etc.), although these changes are strongly coupled. The components of the Earth system respond to climate change and interact in ways that drive non-linear changes in aerosol emissions and sinks. In addition to climate-driven changes in natural aerosol emissions, the aerosol abundance and properties can be influenced by changes in atmospheric composition, in particular the oxidative processes that drive production of secondary aerosol products from the emitted gases. For example, stratospheretroposphere exchange of ozone may increase in a warmer cli- mate (Butchart and Scaife, 2001; Collins et al., 2003), which could lead to increased tropospheric concentrations of ozone, an important oxidant. Atmospheric aerosol is itself a nonlinear system and the impact on climate depends on the microphysical and chemical properties of the particles and not just their mass, and these can change non-linearly with emissions. For example, new particle formation, which is an important source of climate-relevant particles over forests, is suppressed by high particle loadings, so increased aerosol mass due to enhanced primary emissions could reduce net changes in number concentration (e.g. Spracklen et al., 2006; Mönkkönen et al., 2004).

These responses of the natural aerosol system to climate change may constitute a climate feedback. Feedbacks are processes that amplify or dampen the effect of a forcing. The climate system responds to radiative forcings - from greenhouse gases and aerosols in the first place - by adjusting the surface and atmospheric profile of temperature in order to maintain a radiative balance at the top of atmosphere. However various parameters in the climate system respond to the temperature adjustment caused by the initial radiative imbalance. Water vapor, snow albedo and sea-ice albedo are examples of positive feedbacks that amplify the effects of a radiative forcing. Biogeochemical cycles can also play a role in climate feedbacks. While the importance of the carbon cycle in climate feedback is well accepted, the role of aerosols is much less well established. As this review demonstrates, we are beginning to understand how natural aerosols may respond to climate change, but at present the Earth system models required to explore feedbacks are in their infancy.

We focus on four natural aerosol systems: terrestrial biogenic aerosol (including aerosols from biogenic gases and wildfires), marine aerosol, soil and desert dust, and stratospheric and volcanic aerosol. Although we discuss each aerosol system in a separate section, our review highlights that these aerosol systems are not self-contained and that there are interactions and feedback connections between them (Fig. 1). For example, wildfires alter the distribution of vegetation whose emissions of volatile organic compounds account for a large fraction of global sub-micron aerosol mass, and changes in dust emissions directly impact aerosol radiative forcing but may also impact DMS emissions through changes in how dust fertilises the ocean with iron.

The status of our understanding of these aerosol systems and their interactions and feedbacks varies enormously. The DMS-aerosol-cloud-climate feedback (Charlson et al., 1987) is perhaps the most studied, with 20 years of research on marine biota, atmospheric chemistry and aerosol formation (Ayers and Cainey, 2007). Nevertheless, quantitative understanding of the direction and magnitude of the feedback in different parts of the ocean is still lacking. In other cases, such as wildfires, some potential impacts of climate change on regional fire distribution have been investigated but there has been no attempt to study feedbacks in an integrated way or on a global scale. Only in rare cases have these processes 
been incorporated in global models to calculate climate feedback factors.

The review is organized as follows. Sections 2 to 5 describe aerosol processes, interactions and feedbacks related to terrestrial biogenic aerosol, marine aerosol, stratospheric aerosol and dust. These sections describe the main sources of natural aerosol, the climatic factors controlling emissions as derived from observations and process models, and the status of their treatment as components of climate and Earth system models. In Sect. 6 we summarise the status of knowledge, estimate future radiative perturbations due to changes in natural aerosols, and identify where progress is needed.

\section{Terrestrial biogenic systems}

The terrestrial biosphere emits primary biological aerosol particles (PBAP) and trace gas species that oxidise to give products that can partition into the particulate phase to form SOA. The terrestrial biosphere also makes sporadic and very large contributions to atmospheric aerosol during wildfires. In this section we evaluate potential feedbacks between the terrestrial biosphere, atmospheric aerosol and climate. Recent studies have started to quantify these feedbacks, but poorly quantified emissions and a limited understanding of aerosol formation mechanisms mean that the relevant climatic controls are not well defined. The direction and magnitude of future changes in aerosol and precursor gas emissions from the terrestrial biosphere are therefore very uncertain.

The interaction between the terrestrial biosphere and atmospheric aerosol operates in both directions. While the biosphere affects aerosol directly through emissions, the abundance and properties of aerosol can also affect the functioning of the biosphere through effects on photosynthetic radiation and nutrient supply. These effects are evaluated in Sect. 2.4.

\subsection{Secondary organic aerosol from terrestrial sources}

\subsubsection{The impact of secondary organic aerosol on the atmosphere}

Trace gas emissions from the terrestrial biosphere include biogenic volatile organic compounds (BVOCs), such as isoprene, terpenes, acetone and methanol, with an estimated total global source of carbon of $\sim 1100 \mathrm{Tg} \mathrm{a}^{-1}$ (Guenther et al., 1995). There is considerable uncertainty in estimates of the global flux of BVOCs. For example, the global flux of isoprene has been estimated at $412-601 \mathrm{Tg} \mathrm{Ca}^{-1}$ and monoterpenes at $30-128 \mathrm{Tg} \mathrm{Ca}^{-1}$ with the range due to different emission algorithms, vegetation distributions, climatologies, basal emission rates, and spatial and temporal resolutions (Arneth et al., 2008; Schurgers et al., 2009). Once in the atmosphere, some BVOCs react to produce compounds that can partition into the particulate phase, forming SOA. The

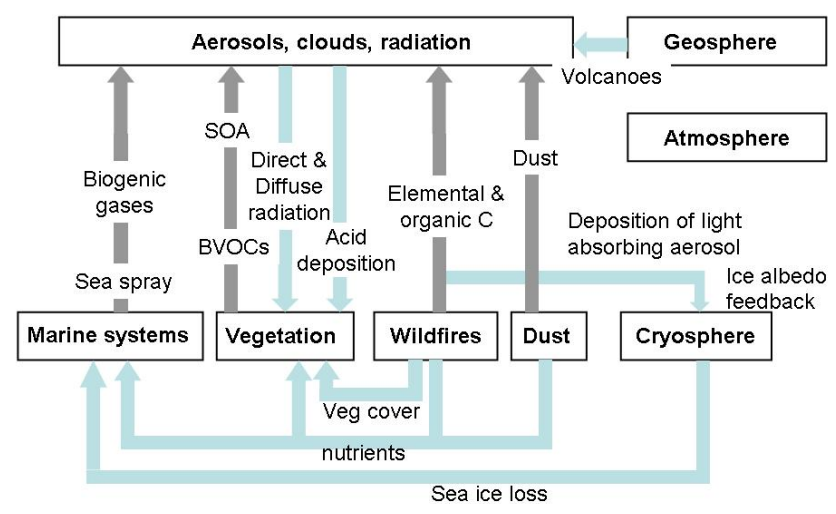

Fig. 1. Interactions between different components of the Earth system connected by aerosol.

budget of SOA is also very uncertain and current best estimates of $12-70 \mathrm{Tg} \mathrm{a}^{-1}$ (Kanakidou et al., 2005) may be up to an order of magnitude too small (Goldstein and Galbally, 2007; Hallquist et al., 2009). This uncertainty is due to our limited understanding of the principal SOA precursor gases including the relative contribution of biogenic and anthropogenic VOCs, the magnitude of their emissions, and the dominant SOA formation mechanisms, which can include condensation and evaporation of semivolatile oxidation products, heterogeneous reactions, cloud processing and oligomerization/polymerization (Fuzzi et al., 2006; Hallquist et al., 2009). This lack of knowledge results in models poorly representing organic aerosol, typically underpredicting the magnitude of observed organic aerosol (de Gouw et al., 2005; Heald et al., 2005; Johnson et al., 2006; Volkamer et al., 2006) and not capturing observed variability (Heald et al., 2006a).

Oxidised organic aerosol dominates sub-micron aerosol mass in a wide range of continental environments (Kanakidou et al., 2005; Zhang et al., 2007a; Chen et al., 2009) and therefore has a direct effect on atmospheric radiation. Additionally, SOA is important for the growth of newly formed particles up to cloud condensation nuclei $(\mathrm{CCN})$ sizes of tens of nanometers (O'Dowd et al., 2002; Allan et al., 2006; Laaksonen et al., 2008) and can therefore affect climate through the aerosol indirect effect. Particle formation (conversion of gas phase species to new particles) is observed in the air above terrestrial ecosystems all around the world (e.g. Kulmala et al., 2004b) and contributes between 5 and $50 \%$ to global mean $\mathrm{CCN}$ concentrations in the boundary layer (Kerminen et al., 2005; Spracklen et al., 2008a). In the boreal forest, the growth of these new particles correlates with seasonal variations in vegetation gross primary productivity and with monoterpene concentrations and radiation (Kulmala et al., 2004a). Biogenic gases may also control particle formation rates directly (Zhang et al., 2004; Verheggen et al., 2007; Bonn et al., 2008). 


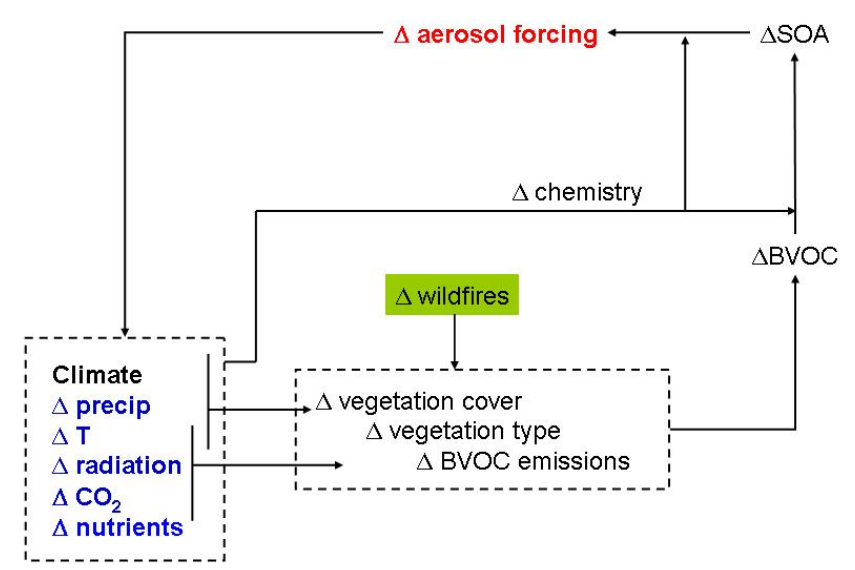

Fig. 2. The response of terrestrial biogenic secondary organic aerosol to climate change. Climate change drivers are indicated in blue, processes in black, and atmospheric impacts in red. The green box contains another set of drivers/feedbacks described in Sect. 2.3.

The contribution of terrestrial ecosystems to SOA is difficult to quantify accurately from observations because anthropogenic aerosol sources can mask natural cycles. Molecular marker methods and ${ }^{14} \mathrm{C}$ analysis suggest that modern carbon from BVOCs, biomass burning and meat cooking dominate total organic carbon aerosol even in urban locations (Hallquist et al., 2009, and references therein). Observations at several boreal forest sites that are relatively free of anthropogenic pollution (Andreae et al., 2007) suggest a very large natural modulation of aerosol by forest emissions. For example, aerosol mass over the Scandinavian forest is proportional to the time that air has spent over the forest (Tunved et al., 2006a), with $12-50 \%$ of aerosol mass and $\sim 50 \%$ of CCN coming from forest sources (Tunved et al., 2008). Kurten et al. (2003) estimated that particle formation over Finnish boreal forest leads to a local radiative perturbation of between -5 and $-14 \mathrm{~W} \mathrm{~m}^{-2}$ (global mean -0.03 to $-1.1 \mathrm{~W} \mathrm{~m}^{-2}$ ), while Spracklen et al. (2008b) predicted that SOA from boreal forest terpene emissions doubles regional CCN concentrations compared to emissions from grassland and causes a local radiative forcing of between -1.6 and $-6.7 \mathrm{~W} \mathrm{~m}^{-2}$ due to changes in cloud albedo. Thus, in the present climate, observations and models suggest that SOA derived from terrestrial ecosystems makes a significant contribution to the radiative budget of the atmosphere.

\subsubsection{Feedback mechanisms involving biogenic SOA}

Figure 2 shows the possible climate feedbacks associated with biogenic SOA. The main driver of the feedback is that climate exerts a strong control over the emission of BVOCs (Sect. 2.1.3). Increases in temperature are likely to lead to increased BVOC emissions and aerosol concentrations, resulting in increased aerosol radiative cooling and a potential negative feedback mechanism (Kulmala et al., 2004a).
However, the atmospheric concentration of SOA is not determined solely by emissions of VOCs, but also by temperature, precipitation and atmospheric chemistry, resulting in non-linear interactions between VOC emissions and the SOA burden (Tsigaridis et al., 2005). The interactions between such processes further complicate how the distribution of SOA might change with climate. For example:

1. Increased temperature causes increased BVOC emissions (e.g., Guenther et al., 1995) but may also reduce the partitioning of semi-volatile compounds to the particles. Increased temperature also modifies vegetation resulting in either further increased or decreased BVOC emissions.

2. Increased $\mathrm{CO}_{2}$ concentrations may directly inhibit leaflevel isoprene emission (Arneth et al., 2007a, b) but the fertilization effect of the $\mathrm{CO}_{2}$ on plant growth can increase emission rates.

\subsubsection{Response of BVOC emissions to environmental change}

Changes in BVOC emissions are an important driver of the feedback between terrestrial ecosystems, aerosol and climate so many studies have sought to understand their response to climate change. Laboratory and field studies show that the emissions are controlled by a complex set of variables including leaf temperature, radiation, nutrient availability, soil moisture, foliar biomass, leaf age, atmospheric composition, vegetation type and species composition (Guenther et al., 1995, 2006), all of which are likely to change with climate. Current BVOC emission algorithms, which are used in models, treat only a subset of these variables. For example, they do not include the effect of changing $\mathrm{O}_{3}$ concentrations (Loreto et al., 2004; Velikova et al., 2005), nutrient availability or physical stress and are only beginning to explore the effects of changing $\mathrm{CO}_{2}$ concentrations.

The observational evidence for large-scale climate-driven changes in BVOC emissions and SOA formation is limited, unlike for wildfires (Sect. 2.3.3). In a good example of such a study, Palmer et al. (2006) used a 6 year record of satellite-observed formaldehyde column to infer a 20-30\% interannual variability in isoprene emission over the southeastern United States driven primarily by variations in surface air temperature. Using a land surface-vegetation model driven by observed climate Lathière et al. (2006) estimate that global emissions of biogenic organics varied by $8 \%$ from 1986 to 1995 . Similarly, Levis et al. (2003) predict that global annual mean biogenic emissions vary by up to $5 \%$ and monthly mean emissions by up to $18 \%$.

The vast majority of model studies of future BVOC emissions have assessed possible changes in isoprene. These studies have taken into account changes in temperature alone, temperature and vegetation, land cover changes, and the influence of $\mathrm{CO}_{2}$ (Table 1). Assuming fixed vegetation, model 
Table 1. Effects of various environmental changes on global BVOC emissions in modeling studies.

\begin{tabular}{|c|c|c|c|c|}
\hline & Scenario & $\Delta$ isoprene emission & $\Delta$ monoterpene emission & Time period \\
\hline \multicolumn{5}{|c|}{ Climate effect only } \\
\hline Wu et al. (2008) & $\mathrm{A} 1 \mathrm{~B} ; \mathrm{CO}_{2} 522 \mathrm{ppmv},+1.6 \mathrm{~K}$ & $+25 \%$ & & $2000-2050$ \\
\hline Sanderson et al. (2003) & IS92a, $+4.7 \mathrm{~K}$ & $+34 \%$ & & 1990-2090 \\
\hline Heald et al. (2008) & $\mathrm{A} 1 \mathrm{~B} ;+1.8 \mathrm{~K}$ & $+22 \%$ & $+19 \%$ & $2000-2100$ \\
\hline Liao et al. (2006) & $\mathrm{A} 2 ;+4.8 \mathrm{~K}$ & $+55 \%$ & $+58 \%$ & $2000-2100$ \\
\hline \multicolumn{5}{|c|}{ Climate effect and dynamic vegetation } \\
\hline Heald et al. (2009) & A1B; 717 ppmv & Factor 3.6 & & $2000-2100$ \\
\hline Turner et al. (1991) & $2 \times \mathrm{CO}_{2}$ & $+25 \%$ & & N/A \\
\hline Sanderson et al. (2003) & IS $92 \mathrm{a},+4.7 \mathrm{~K}$ & $+27 \%$ & & 1990-2090 \\
\hline Lathiere et al. (2005) & $560 \mathrm{ppmv} \mathrm{CO}_{2}$ & $+27 \%$ & $+51 \%$ & $1990-2100$ \\
\hline Wiedinmyer et al. (2006) & $2 \times \mathrm{CO}_{2} ;+1.7 \mathrm{~K}$ & $+70 \%$ & & $1990-2100$ \\
\hline Arneth et al. (2007b) & Various & +77 to $+90 \%$ (A2 SRES); $38 \%$ to $48 \%$ (B1 SRES) & & $1980-2100$ \\
\hline \multicolumn{5}{|c|}{ (Anthropogenic) land cover changes only } \\
\hline Lathiere et al. (2006) & Global tropical deforestation & $-29 \%$ & & - \\
\hline Heald et al. (2008) & A2 & $-15 \%$ & & $2000-2100$ \\
\hline Wiedinmyer et al. (2006) & $\begin{array}{l}\text { Deforestation scenario ( } 50 \% \text { of Amazon and southeast } \\
\text { US deforested) }\end{array}$ & $-9 \%$ & & - \\
\hline Wiedinmyer et al. (2006) & $\begin{array}{l}\text { Biofuel scenario ( } 25 \% \text { of western US and Amazon re- } \\
\text { placed by biofuel plantation) }\end{array}$ & $+37 \%$ & & - \\
\hline Guenther et al. (2006) & IMAGE landcover database & $-30 \%$ & & $2000-2100$ \\
\hline \multicolumn{5}{|c|}{ Climate and $\mathrm{CO}_{2}$ inhibition } \\
\hline Heald et al. (2009) & A1B & $-8 \%$ & & $2000-2100$ \\
\hline \multicolumn{5}{|c|}{ Climate and $\mathrm{CO}_{2}$ inhibition and dynamic vegetation (no anthropogenic vegetation change) } \\
\hline Heald et al. (2009) & A1B & Factor 2.4 & & $2000-2100$ \\
\hline Arneth et al. (2007b) & Various & $-9 \%$ to $-16 \%$ (A1 SRES); $0 \%$ to $-7 \%$ (B1 SRES) & & $1980-2100$ \\
\hline
\end{tabular}

studies with different scenarios for future climate predict a $22 \%$ to $55 \%$ increase in global isoprene emissions by 2100 . Changes in temperature are thought to be the dominant meteorological driver of isoprene emissions, with other variables such as radiation, cloud cover and soil moisture changing by less than 5\% between 2000 and 2100 (Heald et al., 2008). When changes to vegetation are also accounted for there is considerably greater uncertainty in projected emissions (a 25\% to $260 \%$ increase in global isoprene emission by 2100; Table 1) due to the uncertain response of vegetation to future climate and atmospheric $\mathrm{CO}_{2}$ (Sitch et al., 2008). Projected changes to vegetation include longer growing seasons, increased leaf area index, changes in water stress and changes to vegetation distribution including expansion of boreal and temperate forests (Lathière et al., 2005) and dieback of the Amazon forest (Cox et al., 2004, 2008). Nutrient limitations, which are not accounted for in these studies, may limit the response of vegetation making future increases in isoprene emissions more modest. Studies that only account for anthropogenic changes to land-cover typically predict a decline in isoprene emissions of between $9 \%$ and $30 \%$ due to the replacement of forest ecosystems by cropland. In contrast, a future scenario that included widespread adoption of biofuel plantations could result in a $37 \%$ increase in isoprene emissions, due to the large isoprene emission factors of some biofuel crop species.
There have been much fewer studies predicting future monoterpene emissions. Changes to climate alone are predicted to drive a $19 \%$ to $58 \%$ increase in global monoterpene emissions by 2100 (Table 2), whereas one study that combines changes to climate and vegetation predicts a $120 \%$ increase in global emissions.

The impact of changing $\mathrm{CO}_{2}$ concentrations on BVOC emissions is an additional uncertainty that needs to be further understood. Increasing $\mathrm{CO}_{2}$ concentrations may inhibit isoprene emissions (Sharkey et al., 1991; Rosenstiel et al., 2003; Possell et al., 2005; Arneth et al., 2007a) potentially offsetting some of the increased emissions due to higher temperature and changes in vegetation (Table 1). Raisanen et al. (2008) showed that a combination of increased $\mathrm{CO}_{2}$ and temperature can substantially increase monoterpene emissions from Scots Pine trees, but the individual effects were small.

Changes to climate and vegetation between the last glacial maximum (LGM) and 1850 are predicted to have increased isoprene emissions by between $61 \%$ and a factor of 2.6 , while monoterpene emissions have increased by between $51 \%$ and a factor of 3.5 (Adams et al., 2001; Lathière et al., 2005; Valdes et al., 2005; Kaplan et al., 2006). The studies do not agree as to whether the dominant driver of the projected change to BVOC emissions is the direct effect of temperature or climate driven changes to vegetation. 


\subsubsection{The response of biogenic SOA and associated forc- ing to environmental change}

Future SOA mass distributions due to changes in climate, biogenic and anthropogenic emissions, and land use have been predicted by models. These studies typically combine BVOC emission models (Sect. 2.1.3) with global atmospheric chemistry models driven by meteorological output from a general circulation model (GCM). While these studies are the most sophisticated attempts to simulate this complex system they account for a limited range of the variables known to affect SOA. For example, none of these studies accounts for the potential impact of changing $\mathrm{CO}_{2}$ concentrations on BVOC emissions. Many other processes are only partially included or not included at all, for example: future changes in the concentrations of BVOC oxidants (Tsigaridis and Kanakidou, 2007; Heald et al., 2008), and changes in $\mathrm{NO}_{\mathrm{x}}$ (Kroll et al., 2005; $\mathrm{Ng}$ et al., 2007), which affect conversion of BVOCs to SOA. There are also secondary effects of BVOCs on other greenhouse gases due to their impact on oxidants, such as an increased methane lifetime (Valdes et al., 2005; Kaplan et al., 2006; Shindell et al., 2007). Fully coupled Earth system models would need to account for these couplings.

The global SOA mass burden is predicted to increase by between $26 \%$ and $150 \%$ by 2100 (Table 2), resulting in an increase of surface level continental particulate matter concentrations of about $0.5 \mu \mathrm{g} \mathrm{m}^{-3}$. Increased BVOC emissions account for most of the change in SOA, with climate-induced changes in aerosol processes and removal rates having a minor effect ( $-6 \%$ to $+11 \%)$ (Liao et al., 2006; Tsigaridis and Kanakidou, 2007; Heald et al., 2008). The largest future increase in SOA burden is predicted by Tsigaridis and Kanakidou (2007), driven by the largest increase in BVOC emissions, primarily because this study included dynamic vegetation. While the global burden of SOA is projected to increase in a future climate, regional reductions in BVOC emissions and SOA concentrations are possible due to shifts in vegetation (Avise et al., 2009).

We use these studies to estimate that feedbacks due to changing SOA in a future climate (year 2100) will result in a global mean direct radiative perturbation of between -0.04 and $-0.24 \mathrm{~W} \mathrm{~m}^{-2}$ (assuming a present day SOA burden of $0.8 \mathrm{Tg}$ (Tsigaridis and Kanakidou, 2007) and a radiative forcing efficiency of $100 \mathrm{~W} \mathrm{~g}^{-1}$ for particulate organic matter (Forster et al., 2007)). This direct forcing needs to be added to the indirect effect on cloud albedo for which only regional estimates have been made. Tunved et al. (2008) used correlations between observed aerosol at boreal forest sites and calculated monoterpene emissions over back trajectories to estimate that a $1.4 \mathrm{~K}$ increase in temperature would increase CCN concentrations over Scandinavia by $8 \%$ and a $5.8 \mathrm{~K}$ increase in temperature would increase $\mathrm{CCN}$ concentrations by $40 \%$. Using the same approach as Spracklen et al. (2008b), this change in CCN would cause a regional (i.e., forest-wide) radiative perturbation of between -0.6 and $-2.7 \mathrm{~W} \mathrm{~m}^{-2}$ due to changes in cloud albedo, assuming as an upper limit that all the $\mathrm{CCN}$ are active in cloud drop formation. Although not directly comparable, the modeled global changes in SOA mass in Table 2 are similar to this observationally derived estimate of an increase in $\mathrm{CCN}$ over boreal forests. A global model study would be needed to extrapolate this regional indirect radiative perturbation to a global mean so that it could be compared with the global mean indirect forcing from present day anthropogenic emissions, which lies in the range -0.25 to $-1.8 \mathrm{~W} \mathrm{~m}^{-2}$ (Forster et al., 2007). But by assuming (i) a forest coverage of about one-ninth of the Earth's surface, (ii) that the indirect effect is restricted to forests (ignoring aerosol transport), and (iii) that the effects in the boreal forest can be extrapolated to all forests, the global mean indirect effect of changes in biogenic SOA would lie between -0.07 and $-0.3 \mathrm{~W} \mathrm{~m}^{-2}$.

\subsection{Primary biological aerosol particles (PBAP)}

\subsubsection{The impact of PBAP on the atmosphere}

Terrestrial ecosystems emit a wide range of particles directly into the atmosphere, including viruses $(<0.3 \mu \mathrm{m})$, bacteria $(\sim 0.25 \mu \mathrm{m}-10 \mu \mathrm{m})$, fungal spores $(1-30 \mu \mathrm{m})$, pollen $(10$ $100 \mu \mathrm{m})$, plant debris and algae. The global emission source of PBAP is very uncertain but may be as large as $1000 \mathrm{Tg} \mathrm{a}^{-1}$ (Jaenicke, 2005). New observations have demonstrated that in many continental locations PBAP contributes $10-45 \%$ of coarse particulate mass (Elbert et al., 2007) and is capable of acting both as CCN (Ariya et al., 2004) and ice nuclei (Christner et al., 2008; Prenni et al., 2009). In this way PBAP can alter cloud properties and precipitation with potentially important but poorly quantified climate feedbacks. Global atmospheric models are only starting to consider PBAP and a quantitative assessment of their contributions to the global aerosol burden, optical depth and CCN population has not been made.

\subsubsection{PBAP emissions and response to environmental change}

Very little is known about the emission mechanisms or atmospheric drivers of PBAP, but it is likely that the drivers vary with PBAP type and source. Jones and Harrison (2004) reported observed PBAP concentrations that varied with a range of meteorological and phenological variables. Emissions of dry-emitted fungal spores and bacteria are enhanced under warm, dry and windy conditions, requiring wind speeds greater than $\sim 1 \mathrm{~m} \mathrm{~s}^{-1}$ (Jones and Harrison, 2004; Elbert et al., 2007), whereas wet-emitted spores are enhanced by high relative humidity and precipitation (e.g., Zoppas et al., 2006).

The changing distribution of vegetation with climate change may also impact PBAP emissions but it is difficult 
Table 2. Projected change to BVOC emissions (isoprene (I), monoterpenes (M)) and SOA burden by 2100 due to changing climate and emissions.

\begin{tabular}{llllll}
\hline & $\begin{array}{l}\text { Emissions } \\
\text { scenario }\end{array}$ & $\begin{array}{l}\text { Global } \\
\text { surface } \Delta \mathrm{T}\end{array}$ & Vegetation & $\begin{array}{l}\text { Change in BVOC } \\
\text { emissions }\end{array}$ & $\begin{array}{l}\text { Change in } \\
\text { SOA burden }\end{array}$ \\
\hline Liao et al. (2006) & A2 SRES & $+4.8 \mathrm{~K}$ & Fixed & $58 \%(\mathrm{M}), 55 \%(\mathrm{I})$ & $+54 \%(\mathrm{M}$ only) \\
Heald et al. (2008) & A1B SRES & $+1.8 \mathrm{~K}$ & Fixed & $+19 \%(\mathrm{M}),+22 \%(\mathrm{I})$ & $+26 \%$ \\
Tsigaridis and & IS92a & $\begin{array}{l}\text { Uncoupled } \\
(+2 \mathrm{~K} \mathrm{BL},+1 \mathrm{~K} \mathrm{FT})\end{array}$ & Dynamic & $+120 \%(\mathrm{M}),+37 \%(\mathrm{I})$ & $+150 \%$ \\
Kanakidou (2007) & & & & \\
\hline
\end{tabular}

to quantify this effect without a better understanding of the role of vegetation in emissions. Bacterial particle number fluxes are greater over vegetated regions $\left(\sim 500 \mathrm{~m}^{-2} \mathrm{~s}^{-1}\right.$; Lindemann et al., 1982) compared to $100 \mathrm{~m}^{-2} \mathrm{~s}^{-1}$ over bare soil (Lindemann et al., 1982) and $\sim 0.5 \mathrm{~m}^{-2} \mathrm{~s}^{-1}$ over deserts (Lighthart et al., 1994). While fungal spore emissions might also increase with increasing vegetation coverage, emissions have also been observed over desert and ice-covered regions (Griffin et al., 2006; Polymenakou et al., 2008).

Elbert et al. (2007) estimated a fungal spore terrestrial emission rate of $200 \mathrm{~m}^{-2} \mathrm{~s}^{-1}$, irrespective of vegetation type or meteorological conditions, and corresponding to a global emission of $50 \mathrm{Tg} \mathrm{a}^{-1}$. On the global scale, Heald and Spracklen (2009) used observed concentrations of the sugar mannitol, a biotracer of fungal spores, to constrain the fungal PBAP source to $28 \mathrm{Tg} \mathrm{a}^{-1}, 25 \%$ of which was emitted at sizes below $2.5 \mu \mathrm{m}$. Their optimized emissions were based on leaf area index (LAI) and atmospheric water vapor concentrations. Mahowald et al. (2008) estimated a global coarse PBAP emission of $168 \mathrm{Tg} \mathrm{a}^{-1}$ based on above-ground biomass density. Winiwarter et al. (2009) used atmospheric concentrations of cellulose observed in Europe to estimate a plant debris emission rate of $6 \times 10^{-3} \mathrm{~g} \mathrm{~m}^{-2} \mathrm{a}^{-1}$. Using atmospheric concentrations of fungal spores at a site in $\mathrm{Eu}-$ rope they estimate a fungal spore emission rate of between $3 \times 10^{-3}$ and $0.08 \mathrm{~g} \mathrm{~m}^{-2} \mathrm{a}^{-1}$. They scaled these flux estimates to give a European PBAP emission of $0.2 \mathrm{Tg} \mathrm{a}^{-1}$ and a global source of $3 \mathrm{Tg} \mathrm{a}^{-1}$.

It is difficult to quantify the impact of climate change on PBAP emissions without a better understanding of the emission mechanisms and drivers, although projected increases in above-ground biomass and LAI in a future climate are likely to drive increased emissions. The radiative feedback through changed PBAP concentrations is unlikely to be significant but there could be indirect radiative effects through their role as CCN or ice nuclei (Bauer et al., 2003; Ariya et al., 2004; Christner et al., 2008).

\subsection{Wildfires}

\subsubsection{The impact of wildfires on aerosol and climate}

Particles emitted from biomass wildfires are an important constituent of the atmospheric aerosol. They are particularly important for climate because of their light-absorbing properties, which can affect absorption of radiation in the atmosphere and at the surface when the particles are deposited on snow and ice. Penner et al. (2001) reported global emissions of organic matter of $45-80 \mathrm{Tg} \mathrm{a}^{-1}$ and of black carbon (BC) of 5-9 $\mathrm{Tg} \mathrm{a}^{-1}$ for biomass burning (including biofuels). More recent inventories of large-scale (or open) burning rely on remote sensing estimates of fire counts (Generoso et al., 2003) or area burned (Hoelzemann et al., 2004; van der Werf et al., 2004). The range of estimates for annual emissions of particulate organic matter from wildfires is 20 to $35 \mathrm{Tg} \mathrm{a}^{-1}$ (see Fig. D1 in Dentener et al., 2006).

Biomass burning aerosols scatter and absorb solar radiation and there is no agreement on the sign of their direct radiative forcing at the global scale (Forster et al., 2007), with some models predicting a positive radiative forcing and others a slightly negative radiative forcing (range -0.05 to $0.22 \mathrm{~W} \mathrm{~m}^{-2}$ ). It is conceivable that aerosols from wildfires contribute to either warm or cool the climate depending on which season or region or from which ecosystems they are emitted.

The climate impact of wildfires is not limited to the direct effect on aerosols and aerosol precursors. Aerosols from wildfires may affect the amount of direct and diffuse solar radiation at the surface as well as precipitation through their role as cloud condensation nuclei (Andreae et al., 2004), which may affect ecosystem productivity and vegetation dynamics. In addition, deposition of light-absorbing particles on snow and ice reduces the albedo and may accelerate warming of Arctic regions (Quinn et al., 2008). Flanner et al. (2007) have shown that the local efficacy (temperature response to a given radiative forcing) of $\mathrm{BC} /$ snow forcing is more than three times greater than for $\mathrm{CO}_{2}$ because of the strong effect of the $\mathrm{BC}$ on snow melting rates, which amplifies the snow-albedo feedback. 


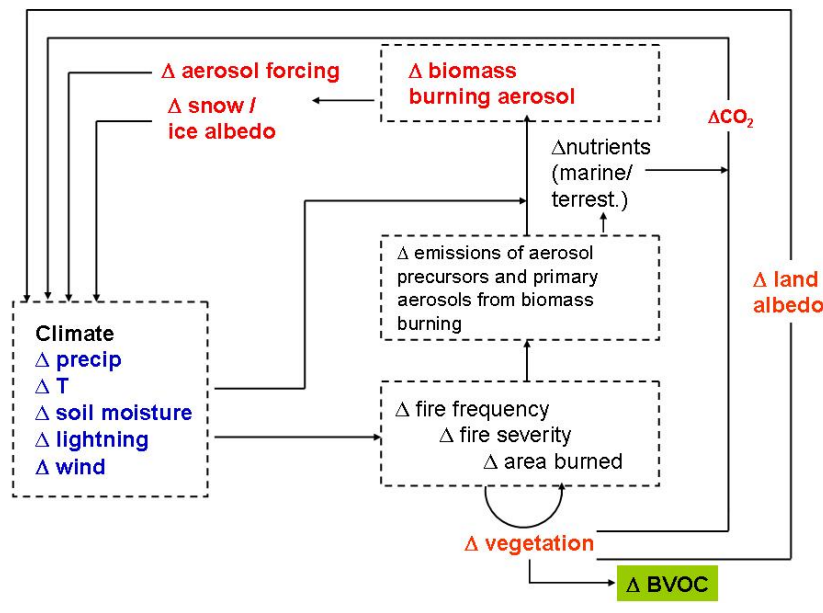

Fig. 3. Possible feedbacks associated with wildfires. Climate change drivers are indicated in blue, processes in black, atmospheric impacts in red. The green box contains another set of drivers/feedbacks described in Sect. 2.1.2. Primary biological aerosol particles are not included.

\subsubsection{Feedback processes involving wildfires}

Figure 3 shows the possible climate feedbacks associated with wildfire aerosols. The main driver of the feedback is that climate exerts a strong control over the frequency and severity of fires. Most studies point to an increase in wildfires in a future climate (Sect. 2.3.3). However, given the current uncertainties in the atmospheric and cryospheric effects of wildfire aerosol just described it would be speculative at this stage to try to close the global climate feedback loop involving wildfires and aerosols. The Arctic is one region of the globe where the feedback is most likely to be positive: barring any induced atmospheric circulation changes, increased deposition of light-absorbing wildfire particles on snow will accelerate melting of snow and ice.

In addition to the direct effect of the emitted particles on atmospheric radiation and surface albedo, destruction of forests by wildfires also affects the subsequent emission of BVOCs and formation of SOA long after the fire aerosols have been removed from the atmosphere (Sect. 2.3.3.3). The net impact of climate change on aerosol emissions from the terrestrial biosphere will need to account for this coupling.

It is important to note that the breakdown of wildfires and related emissions between natural and man-made origin is still being discussed. It is generally argued that i) emissions due to deforestation in the tropics have scaled with population over the last two centuries; ii) forest burning emissions at high latitudes of the Northern Hemisphere are lower now than in the past because of forest management and fire suppression policies (e.g. Marlon et al., 2008); and iii) some ecosystems, such as savannas, are essentially fire-regulated systems and would burn regularly irrespective of anthropogenic pressures. However, these are generalizations, and it is likely that in many regions wildfires occur because of a mix of natural and anthropogenic factors (van der Werf et al., 2008). This should be kept in mind when discussing possible climate feedbacks involving wildfires as these feedbacks could be different in the absence or presence of anthropogenic factors.

\subsubsection{Response of wildfires to climate change}

Emissions from wildfires show considerable interannual variability of more than a factor 2 partly in response to climate (Generoso et al., 2003; van der Werf et al., 2004; Schultz et al., 2008). For example, fire emissions are larger during El Niño years because drought conditions associated with El Niño trigger an increase in fire activity. Decadal climate change may be changing the occurrence of forest fires in some regions (Gillett et al., 2004; Westerling et al., 2006), although the global mean $\sim 50 \%$ increase in wildfire carbon emissions from the 1960s to 1990s is most likely due to increased deforestation (Schultz et al., 2008). Marlon et al. (2008) have shown variations on even longer timescales in relation to both climate change and anthropogenic activities.

\subsubsection{Changes in the occurrence of fires}

There are several possible effects of climate change on the occurrence of wildfires. Fires require fuel availability, readiness of the fuel to burn depending on the atmospheric and soil conditions, and an ignition source (be it natural or anthropogenic). Moisture is one of the most relevant parameters for fires and drought indices have been used as a proxy to infer fire risk in the future climate (e.g., Burke et al., 2006). Cox et al. (2004) predicted a dieback of the Amazon rainforest in coupled climate-carbon cycle simulations for the 21 st century because of a significant shift in precipitation patterns over this region. One mechanism for the Amazon dieback would be through increased fire disturbances in the context of sustained drought (Laurance and Williamson, 2001; Nepstad et al., 2004; Aragão et al., 2008).

Several studies have projected the change in wildfire in a future climate, the majority of which focus on North America (Flannigan et al., 2009). For the United States Bachelet et al. (2003) predicted an increase in the total biomass burnt using two Dynamic Global Vegetation Models (DGVM) fed by two climate change scenarios. Westerling et al. (2006) attribute the observed increase in wildfire activity in the Western United States to an increase in spring and summer temperature, which are responsible for an earlier melting of mountain snowpacks. The same process could be at work under climate change in this region where both a temperature increase and a precipitation decrease are predicted by climate models (Running, 2006). Increased wildfire due to climate change has also been projected for Canada (e.g., Flannigan and Van Wagner, 1991; Wotton and Flannigan, 1993; Stocks 
et al., 1998; Flannigan et al., 2005), North America (Flannigan et al., 2000), Russia (Stocks et al., 1998), Western United States (Brown et al., 2004; Westerling and Bryant, 2008) and Europe (Mouillot et al., 2002; Morriondo et al., 2006). Flannigan et al. (2005) projected area burned to increase by 74 $118 \%$ in Canada by the end of this century in a $3 \times \mathrm{CO}_{2}$ scenario. These estimates do not explicitly take into account any changes in vegetation, ignitions, and human activity (fire management and land use activities) that may also influence area burned. In the Amazon, forest fires are closely related to both rainfall and the amount of human disturbance: future development of the Amazon is projected to increase fire activity there by between $22 \%$ and $123 \%$ (Cardoso et al., 2003).

Changes in ignition sources are likely to be important. Price and Rind (1994) projected that increased convection under a $2 \times \mathrm{CO}_{2}$ scenario leads to increased lightning and a $78 \%$ increase in area burned in the United States.

Amiro et al. (2009) made the first projections of future wildfire emissions accounting for both changes to area burned and wildfire severity. They find that changes to wildfire ground fuel biomass consumption in the Canadian boreal forest region are driven mainly by changes in area burned with limited contribution from increased fire severity. They project that biomass consumption increases by $33 \%$ in a $2 \times \mathrm{CO}_{2}$ scenario and $95 \%$ in a $3 \times \mathrm{CO}_{2}$ scenario.

While the majority of studies point to a future increase in wildfire, decreased area burned has been projected for parts of Eastern Canada due to projected increases in precipitation (Bergeron and Flannigan, 1995; Flannigan et al., 2001).

\subsubsection{Changes in wildfire aerosol emissions}

There are very few studies of the change in aerosol emissions and concentrations due to the change in wildfires. Interannual variability in wildfires has been shown to be the dominant driver of observed variability in summertime organic carbon concentrations in the Western United States (Spracklen et al., 2007a; Jaffe et al., 2008). Spracklen et al. (2009) investigated the impact of future climate change on wildfire activity and carbonaceous aerosol concentrations in the same region. After analyzing the association of past fires and meteorology they used a GCM to show that increases in temperature by 2050 will cause annual mean area burned in the Western United States to increase by $54 \%$ and the wildfire carbonaceous emissions to increase by $90 \%$ relative to present day. Summertime organic carbon (OC) aerosol concentrations over the Western United States were projected to increase by $40 \%$ and elemental carbon concentrations by $20 \%$. This study suggests that wildfire will be the dominant driver of the increase in OC aerosol in the Western United States, causing $75 \%$, with changes to climate and SOA being responsible for the remainder.

It is worth noting that predicting future changes in area burned is not the same as predicting future changes in emissions. There might be a negative feedback whereby more fires eventually imply less biomass to burn. Some authors have argued that this may not be the case in boreal forests as these have sustained more fires in the past in the absence of fire suppression policies. However there would be other ecosystems where wildfires caused by climate change would trigger large initial emissions of carbon and aerosols followed by a shift in ecosystems through vegetation dynamics. Clearly more elaborate modeling of the interaction between vegetation dynamics, wildfires and emissions is needed.

\subsubsection{Coupled impacts of wildfires on greenhouse gases, albedo and aerosol emissions}

The studies highlighted above have investigated the impact of climate change on wildfires and, in very limited cases, the subsequent effects on aerosols. However, the net climate impact of fires needs to account for wider Earth system couplings.

Randerson et al. (2006) have attempted to integrate the effect of a boreal forest fire on greenhouse gases, aerosols, black carbon deposition on snow and sea ice, and postfire changes in local surface albedo. They estimate that the radiative forcing of mature boreal forest compared with forest over an 80-year fire cycle was a warming of $2.3 \pm 2.2$ Watts per square metre of forest burned (due to contributions from storage of carbon of $-1.6 \pm 0.8 \mathrm{~W} \mathrm{~m}^{-2}$, the lower albedo of the forest compared to the burned area of $+4.2 \pm 2.0 \mathrm{~W} \mathrm{~m}^{-2}$, and a negligible radiative forcing due to smoke emissions when averaged across the fire life cycle). This result would mean that future increases in boreal fire would not accelerate climate warming. However, there are further radiative effects of fire through aerosol generated by forest BVOC emissions. Spracklen et al. (2008b) used a global aerosol model to predict that boreal forest terpene emissions contribute $50 \%$ of regional (north of $60^{\circ} \mathrm{N}$ ) $\mathrm{CCN}$ concentrations and cause a local (forest-wide) indirect aerosol radiative forcing of between -1.6 and $-6.7 \mathrm{~W} \mathrm{~m}^{-2}$ compared to grassland (Sect. 2.1.1), which may compensate the net positive forcing estimated by Randerson et al. (2006). Thus at present the long term climate impact of forest fires is not certain.

\subsection{Aerosol impacts on terrestrial systems}

This review mainly addresses the impact of climate change on natural aerosols. For completeness, we briefly review the effects of all aerosol on the terrestrial biosphere. The two main processes of interest are the effect of aerosol on diffuse radiation entering the biosphere and the supply of nutrients from aerosol. Most studies have considered the effects of anthropogenic aerosol on these processes and the impact on the carbon cycle, which is not our interest here. However, natural aerosols may play an important role in some environments. 


\subsubsection{Impact of aerosol radiative effects on vegetation}

Aerosols decrease the solar radiation reaching the surface, especially in the 0.45 to $0.75 \mu \mathrm{m}$ wavelength range (known as photosynthetically available radiation, or PAR), which may have an impact on plant productivity and therefore on the carbon cycle. Aerosols can also increase the diffuse radiation reaching the surface, which is known to enhance plant productivity (e.g., Gu et al., 2002). It has been suggested by several authors that the increase in diffuse radiation due to stratospheric aerosols following large volcanic eruptions may be responsible for an additional uptake of carbon dioxide by terrestrial ecosystems (Gu et al., 2003). This effect was modeled by Mercado et al. (2009) who concluded that not only transient increases in stratospheric aerosol loadings but also the centennial trend in tropospheric aerosols due to anthropogenic emissions are responsible for an enhancement of the terrestrial carbon sink. If the burden of natural aerosols were to change over vegetated areas then the same process would apply. This process can provide a negative climate feedback if natural aerosols increase in response to climate change (e.g. larger temperature leads to enhanced BVOC emissions, increased SOA burden, increased diffuse radiation, increased carbon uptake leading to less severe temperature change (Kulmala et al., 2004a)).

\subsubsection{Natural aerosols as a source of nutrients for vege- tation}

The wet and dry deposition of particulates to the Earth's surface may contribute a significant nutrient source to some ecosystems (Fig. 1), but in polluted regions excessive deposition of acidic particles can damage vegetation and lead to acidification of soils. Deposition of particles on leaf surfaces can also alter leaf-surface wetness, altering ecosystem water and $\mathrm{CO}_{2}$ uptake and the risk of pathogen attack (Cape, 2008).

Much previous research has focused on Amazonian ecosystems which are thought to rely heavily on external inputs of nutrients because their soils are highly weathered and nutrient limited. Biomass burning is also a significant source of carbon, sulphur, nitrogen and phosphorouscontaining compounds to downwind ecosystems. Biomass burning in the Amazon basin results in significant deposition of sulphur to downwind ecosystems (Fabian et al., 2005). While the deposition of phosphorous on a global scale is dominated by dust $(82 \%)$ and primary biological aerosol particles (13\%) (Mahowald et al., 2008), biomass burning may be the dominant source of phosphorous to the Amazon basin (Mahowald et al., 2005). Increased biomass burning in the Amazon due to land-use change is likely leading to increased deposition of phosphorous to undisturbed Amazonian forests, where it may be contributing to observed increases in carbon sequestration. Deposition to the oceans may also fertilize phosphorous-limited waters (Mills et al., 2004).
Such natural aerosol nutrient sources are likely to be much less important than anthropogenic aerosol in more polluted environments. For example, enhanced nitrogen deposition from anthropogenic aerosol sources (Cape, 2008) may be driving net carbon sequestration in boreal and temperate forest ecosystems (Mencuccini et al., 2007). Acid deposition from anthropogenic emissions has also resulted in extensive forest dieback (e.g. Driscoll et al., 2001) but the impact on the global carbon cycle has not been quantified. Sulphate deposition also impacts natural wetlands and rice paddies resulting in suppressed methane emissions (Gauci et al., 2008). The future deposition of particulates to ecosystems will depend on both changes to anthropogenic emissions and climate (e.g., Tagaris et al., 2008).

\subsection{Summary and status of terrestrial biogenic aerosol in Earth system models}

Tables 3 and 4 summarise the likely aerosol-climate feedbacks associated with biogenic SOA and wildfire aerosols as well as the priorities for future research and model development. Current studies suggest that biogenic SOA could increase by between 25 and $150 \%$ in a future climate. This increase is estimated to cause a global mean direct aerosol radiative perturbation of between -0.04 and $-0.24 \mathrm{~W} \mathrm{~m}^{-2}$. The local (forest-scale) indirect radiative perturbation has been estimated to be as high as $-2.7 \mathrm{~W} \mathrm{~m}^{-2}$ with a global mean of $-0.3 \mathrm{~W} \mathrm{~m}^{-2}$ (Sect. 2.1.4). Future increases in biogenic SOA are therefore likely to cause a large negative climate feedback. Wildfires are also predicted to increase, causing possible regional increases of up to $40 \%$ in organic aerosol loading. The direction and magnitude of the wildfire aerosol climate feedback is uncertain because the net radiative effect of wildfire aerosol is also uncertain.

Earth system model descriptions of these biogenic aerosols are at an early stage. GCMs have been developed that include BVOC emission models coupled to atmospheric chemistry models. At present they account only for a limited range of the variables known to affect BVOC emissions and SOA formation (Sect. 2.1.3). Ultimately, Earth system models will couple sub-models representing vegetation dynamics and the carbon cycle, nutrient availability, mechanistic treatments of wildfire occurrence and the factors that control BVOC emissions, together with sophisticated atmospheric models of SOA formation and properties.

Expanding the set of drivers used to calculate BVOC emissions in models is necessary. In particular, including the effects of soil nutrient limitations, atmospheric carbon dioxide and ozone may greatly alter our understanding of how BVOC emissions and SOA will change in the future. There is also a need to develop algorithms that are less empirical and more process-based. Current BVOC emission algorithms assume that the response observed over a period of days to weeks is applicable over annual to decadal timescales (Guenther et al., 2006). The impact of climate on vegetation 
Table 3. Status of terrestrial biogenic secondary organic aerosol (SOA) in Earth system models, developments needed, key observations, magnitude of radiative effect in 2100 , and the level of scientific understanding.

\begin{tabular}{|c|c|c|c|c|c|c|}
\hline Global model status & $\begin{array}{l}\text { Model challenges and } \\
\text { developments }\end{array}$ & Priority & Key observations needed & Priority & $\begin{array}{l}\text { Direction and magni- } \\
\text { tude of feedback by } \\
2100\end{array}$ & LOSU \\
\hline $\begin{array}{l}\text { - Some studies of the } \\
\text { effect of } \mathrm{T} \text { on BVOC } \\
\text { emissions (mostly iso- } \\
\text { prene and monoterpenes) } \\
\text { based on semi-empirical } \\
\text { models. }\end{array}$ & & & chemistry and budget & & $\begin{array}{l}\text { Likely increase in } \\
\text { global biogenic SOA } \\
(25 \text { to } 150 \%) \text {. } \\
\text { Likely negative radia- } \\
\text { tive forcing and feed- } \\
\text { back. }\end{array}$ & \multirow{5}{*}{ Poor } \\
\hline \multirow{4}{*}{$\begin{array}{l}\text { - Limited studies of the } \\
\text { effect of } \mathrm{CO}_{2} \text { and vege- } \\
\text { tation changes on BVOC } \\
\text { emissions. } \\
\text { - Limited studies of the } \\
\text { impact of changing cli- } \\
\text { mate and BVOC emis- } \\
\text { sions on SOA. }\end{array}$} & \multirow{2}{*}{$\begin{array}{l}\text { Expanded range of bio- } \\
\text { genic emission drivers } \\
\text { and process-based emis- } \\
\text { sion algorithms (temper- } \\
\text { ature, soil nutrients, ni- } \\
\text { trogen deposition, } \mathrm{CO}_{2} \text {, } \\
\text { ozone, etc). }\end{array}$} & \multirow[t]{2}{*}{ High } & \multirow[t]{2}{*}{$\begin{array}{l}\text { Continuous and compre- } \\
\text { hensive measurements to } \\
\text { observe soil, ecosystem } \\
\text { and atmosphere relations }\end{array}$} & \multirow[t]{2}{*}{ High } & \multirow{4}{*}{$\begin{array}{l}\text { Biogenic } \\
\text { global mean direct } \\
\text { forcing }-0.04 \text { to } \\
-0.24 \mathrm{~W} \mathrm{~m}^{-2} \\
\text { Local (over forest) } \\
\text { indirect forcing }-0.6 \\
\text { to }-2.7 \mathrm{~W} \mathrm{~m}^{-2} \text {. } \\
\text { Globally maximum of } \\
-0.3 \mathrm{~W} \mathrm{~m}^{-2} \text {. }\end{array}$} & \\
\hline & & & & & & \\
\hline & $\begin{array}{l}\text { Expanded range of emit- } \\
\text { ted compounds (e.g., } \\
\text { sesquiterpenes) and } \\
\text { controlling factors }\end{array}$ & Medium & $\begin{array}{l}\text { Interannual variations in } \\
\text { emissions and drivers. }\end{array}$ & High & & \\
\hline & $\begin{array}{l}\text { Size-segregated aerosol } \\
\text { dynamics }\end{array}$ & Medium & $\begin{array}{l}\text { Physico-chemistry of the } \\
\text { gas-aerosol equilibrium } \\
\text { of semi-volatile organic } \\
\text { species. }\end{array}$ & Medium & & \\
\hline
\end{tabular}

Table 4. Status of wildfire aerosol in Earth system models, developments needed, key observations, magnitude of radiative effect in 2100, and the level of scientific understanding.

\begin{tabular}{|c|c|c|c|c|c|c|}
\hline Global model status & $\begin{array}{l}\text { Model challenges and } \\
\text { developments }\end{array}$ & Priority & Key observations needed & Priority & $\begin{array}{l}\text { Direction and magnitude of } \\
\text { feedback by } 2100\end{array}$ & LOSU \\
\hline $\begin{array}{l}\text { - Very limited uncou- } \\
\text { pled regional studies } \\
\text { of changes in burned } \\
\text { area with climate } \\
\text { change }\end{array}$ & $\begin{array}{l}\text { Coupling of fire models } \\
\text { and vegetation models } \\
\text { resolving fire dynamics } \\
\text { on multiple timescales. }\end{array}$ & High & $\begin{array}{lr}\text { Optical properties } \\
\text { of biomass burning } \\
\text { aerosols. }\end{array}$ & High & \multirow{2}{*}{$\begin{array}{l}\text { - Likely increase in wild- } \\
\text { fire occurrence }(\sim 100 \% \\
\text { possible) and carbonaceous } \\
\text { aerosol concentrations (up } \\
\text { to } 40 \%) \text {. } \\
\text { - Global mean radiative } \\
\text { perturbation positive or } \\
\text { negative. Positive perturba- } \\
\text { tion in Arctic }\end{array}$} & \multirow[t]{2}{*}{ Very poor } \\
\hline $\begin{array}{l}\text { - No global studies } \\
\text { of wider Earth system } \\
\text { interactions }\end{array}$ & $\begin{array}{l}\text { Global analysis of } \\
\text { response to climate } \\
\text { change. }\end{array}$ & High & $\begin{array}{l}\text { Records of deposition on } \\
\text { snow and ice, including } \\
\text { optical properties. }\end{array}$ & Medium & & \\
\hline
\end{tabular}


type and distribution is also likely to be important and is only now being included in simulations of aerosol (Tsigaridis and Kanakidou, 2007).

The poorly constrained SOA budget represents a major limitation in accurately quantifying changes due to climate. Current models may underpredict atmospheric SOA by up to an order of magnitude (Volkamer et al., 2006) with unknown consequences when these models are used for chemistryclimate predictions. Previous studies have focused on the SOA production from monoterpenes, isoprene and anthropogenic organics. The emissions of other SOA precursors such as sesquiterpenes may be very strongly temperature dependent (Duhl et al., 2008) and so their contribution to SOA may be greater in a warmer climate.

Previous studies have been limited to an assessment of the change to SOA mass budgets. While new global aerosol microphysics models can predict aerosol size distribution, these models have yet to be applied to changing BVOC emissions and SOA with a changing climate. This is an important step that is required before an accurate assessment of future impact on the aerosol indirect effect can be made, but perhaps less urgent than quantifying the SOA mass budget.

Current Earth system models include interactive aerosols and an interactive carbon cycle with vegetation dynamics (Sect. 2.1.3). However disturbances to the vegetation caused by pests and wildfires are not represented explicitly. There is ongoing work to estimate fire index, fire risk and fire emissions as diagnostics in climate models. Some fire models have been coupled to dynamic vegetation models (Bachelet et al., 2003; Arora and Boer, 2005) but not yet interactively as part of a climate model where the potential for real or spurious feedbacks is greater. However the next generation of Earth system models is expected to explicitly couple fire models with dynamics vegetation models (e.g. Spessa et al., 2008). There is also a need for models to couple the biophysical effects of forests (albedo, evapotranspiration, roughness length, etc.), the biogeochemical effects $\left(\mathrm{CO}_{2}\right.$ sequestration, etc.) with the capacity of forests to produce aerosol (Sect. 2.3.3.3). Such increasingly complex model simulations of climate impacts of fire aerosol will require an improved understanding of the aerosol optical properties so that the net radiative effect of changes in aerosol load can be quantified. Observations or reconstructions of fire occurrence will remain high priority so that increasingly complex models can be evaluated.

\section{Marine aerosols}

This section considers the response to climate change of aerosol produced directly or indirectly by marine regions. A wide range of responses have been studied based on observations and models, and several processes have been included in coupled ocean-atmosphere models to quantify the feedback on climate. The most extensively studied oceanic response to climate is that of dimethylsulphide (DMS or $\mathrm{CH}_{3} \mathrm{SCH}_{3}$ ) produced by phytoplankton, which is a major source of aerosol (Shaw, 1983; Charlson et al., 1987). Recent observations have led to an improved understanding of emissions of other primary and secondary aerosol components, which are also driven by biological activity, and suggest that a wider range of climate-emission feedbacks need to be considered.

\subsection{Plankton, dimethylsulphide emissions and sulphate aerosol}

\subsubsection{The impact of DMS on atmospheric aerosol}

DMS originates from the decomposition of dimethylsulphoniopropionate (DMSP) produced by marine organisms, particularly phytoplankton. It is found in varying concentration in seawater and is emitted into the atmosphere. Products of the gas phase of DMS contribute substantially to the mass of atmospheric aerosol. The sequence of reactions responsible for oxidation of DMS (Koga and Tanaka, 1999) begins with the reactions of DMS with $\mathrm{OH}$ and $\mathrm{NO}_{3}$, also involves $\mathrm{O}_{3}, \mathrm{HO}_{2}$ and $\mathrm{H}_{2} \mathrm{O}_{2}$, and results in the eventual production of $\mathrm{SO}_{2}$, methanesulphonic acid and gas-phase sulphuric acid $\left(\mathrm{H}_{2} \mathrm{SO}_{4}\right)$ which can then condense onto aerosol particles (Pham et al., 1995) or nucleate to form new sulphuric acid particles (Kulmala et al., 1998). Chemical transport model studies suggest that between about 18 and $42 \%$ of global atmospheric sulphate aerosol is derived from DMS (Chin and Jacob, 1996; Gondwe et al., 2003; Kloster et al., 2006). Chin and Jacob (1996) also estimated that DMS accounts for $20-80 \%$ of sulphate in surface air over the Northern Hemisphere oceans and over $80 \%$ in most of the Southern Hemisphere and in the upper troposphere.

The climate impact of DMS depends on the ability of its oxidation products to increase the CCN (and ultimately the cloud drop number) population, and not just the sulphate aerosol mass. CCN concentrations at a given supersaturation are influenced by DMS through growth of small particles to $\mathrm{CCN}$ sizes from condensation of $\mathrm{H}_{2} \mathrm{SO}_{4}$, through nucleation of new $\mathrm{H}_{2} \mathrm{SO}_{4}-\mathrm{H}_{2} \mathrm{O}$ particles that eventually grow to $\mathrm{CCN}$ sizes, and through formation of aerosol sulphate from the oxidation of $\mathrm{SO}_{2}$ in cloud drops.

Current global aerosol microphysics models (e.g., Spracklen et al., 2005; Adams and Seinfeld, 2002; Stier et al., 2005) include the microphysical processes needed to simulate such processes explicitly. Using such a 3-D model, Korhonen et al. (2008) were able to reproduce the observed CCN seasonal cycle at Cape Grim (Ayers et al., 1997) and estimated a peak (summer) zonal mean contribution of DMS to marine boundary layer (MBL) CCN in the Southern Ocean of between 18 and $46 \%$ depending on latitude, which is less than the $80 \%$ estimated from satellite observations (Vallina et al., 2006). They also showed that about $90 \%$ of the MBL CCN produced by DMS originated as nucleated particles in 
the free troposphere. This finding is consistent with earlier studies of the MBL (Raes et al., 1995) and detailed column model studies (Caffrey et al., 2006).

The observed and modeled correlation of DMS, aerosol sulphate, $\mathrm{CCN}$ and cloud properties on seasonal timescales (Ayers and Gras, 1991; Ayers et al., 1997; Boers et al., 1994; Korhonen et al., 2009) suggests that phytoplankton dynamics, DMS emissions and aerosol and cloud microphysics are linked. Nevertheless, despite more than 20 years of research since the original proposal of a climate feedback involving DMS (Shaw, 1983; Charlson et al., 1987), the magnitude and direction of the feedback remains uncertain (Ayers and Cainey, 2007).

\subsubsection{Feedback processes involving DMS and aerosol}

The climate feedback involving DMS emissions and aerosol (Fig. 4) has become known as the CLAW hypothesis after the authors of Charlson et al. (1987). At the most basic level, it is hypothesized that the emitters of DMS (phytoplankton) will respond to climate change and thereby affect the abundance of sulphate aerosol, and hence cloud properties and climate. Although CLAW is often cited as an example of a negative climate feedback, there are several scenarios in which the direction of feedback is uncertain. Furthermore, it is likely that different responses may operate together or in different regions or seasons (Boyd, 2002).

Several potential feedbacks are driven by changes in temperature and wind speed. A feedback that is likely to be negative is the reduction of the mixed layer depth (shoaling) due to atmospheric warming, causing phytoplankton to reside closer to the water surface, resulting in an increase in the received solar radiation dose (SRD) and increased DMS emission (Vallina and Simo, 2007a, b; Vallina et al., 2007a, b), although Larsen et al. (2008) has cautioned that changes in the different wavelength components of SRD could have different and perhaps compensating effects on DMS emissions. The mechanism is consistent with laboratory experiments showing that plankton DMSP production increases in response to solar radiation (Sunda et al., 2002). Although SRD and DMS are strongly correlated in the global ocean (Vallina et al., 2007a; Vallina and Simo, 2007b) the impact of climate change in a model seems to be small (Vallina et al., 2007b). However, Behrenfeld et al. (2006) suggest that the warming-induced increase in ocean stratification could reduce the supply of nutrients from deeper waters, limiting plankton growth, which would constitute a positive feedback. Changes in ocean temperature and stratification can also result in shifts in ecosystem flora and structure (Boyd and Doney, 2002; Bopp et al., 2003). Increased wind speeds, and hence surface wind stress, result in deepening of the wind mixed-layer, which affects nutrient availability in an uncertain way. It also causes increased DMS air-sea exchange (Gabric et al., 1998), which alone would be a negative feedback, but also increases the sea spray flux (Sect. 3.2.1),

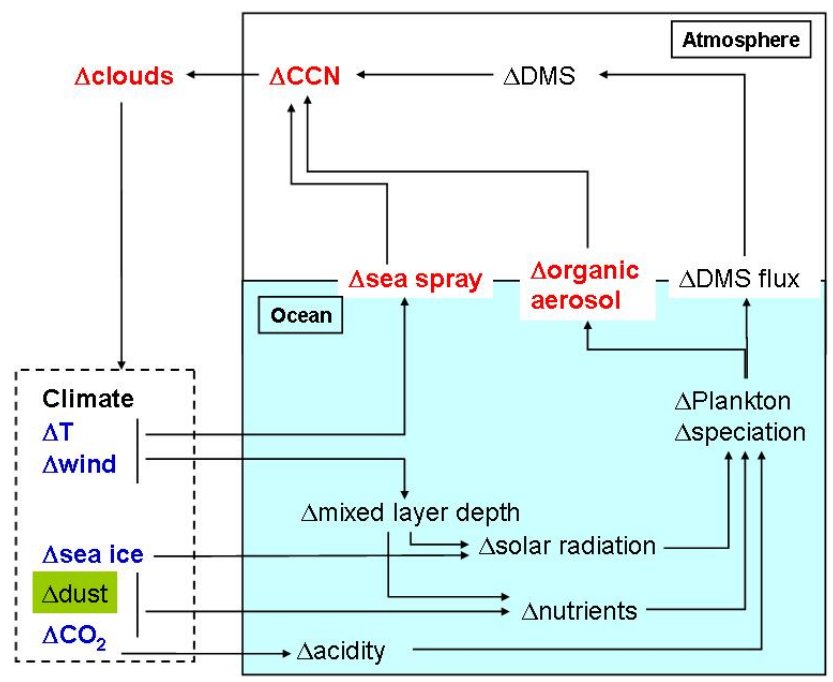

Fig. 4. The response of marine primary and secondary aaerosol to climate change. Climate change drivers are indicated in blue, processes in black, and impacts in red. The green box includes a separate set of feedbacks discussed in Sect. 5.

which will impact atmospheric DMS oxidation in an as yet unquantified way (von Glasow, 2007).

Global satellite observations have been used to study the link between ocean productivity and climate, although the main indicator of productivity (chlorophyll) may not be a good indicator of changes in DMS itself. Gregg and Conkright (2002) showed that global mean ocean chlorophyll decreased by about $6 \%$ from the 1980 s to 2000 with substantial regional variability most likely attributable to natural variability in wind stress, ocean warming and cooling. Behrenfeld et al. (2006) have shown using satellite observations of ocean color that ocean productivity has varied substantially over the past decade, most likely driven by climate induced changes in ocean stratification and nutrient supply. On a smaller scale, observations suggest a positive correlation between anomalies in sea water temperature and DMS in the Southern Indian Ocean, amounting to a 50\% increase in DMS for a $1 \mathrm{~K}$ increase in temperature (Sciare et al., 2000b), although the cause was not established.

Several other drivers of changes in DMS production and emission have been proposed.

1. Retreat of Arctic summer sea ice exposes more water to solar radiation, which may lead to enhanced DMS production and emission (Gabric et al., 2005). In contrast, in the Southern Hemisphere Curran et al. (2003) showed that methanesulphonic acid (an oxidation product of DMS) has decreased by about 20\% in Antarctic ice cores since the 1950s. This decrease is consistent with decreases in sea ice extent and the dominant source of DMS being from sea-ice algae. Increased aerosol optical depth during spring sea ice melt may provide 
corroborating evidence (Gabric et al., 2005) but effects of changes in temperature and atmospheric dynamics on DMS chemistry were not investigated. Thus, changes in sea ice may have opposite effects on DMS emissions in the Northern and Southern Hemispheres.

2. Increasing $\mathrm{CO}_{2}$ raises ocean acidity (Caldeira and Wickett, 2003) resulting in physiological changes to plankton (Wingenter et al., 2007) and changes in DMS emission. However, the response of plankton communities to increased $\mathrm{CO}_{2}$ and warming is complex and responses are not consistent across experiments (Vogt et al., 2008).

3. Changes in atmospheric dust due to changes in wind or vegetation influences iron fertilization and plankton growth (Jickells et al., 2005) - Sect. 5.2.2. Iron fertilization experiments have produced conflicting results (Boyd et al., 2007) and are difficult to extrapolate to regional and seasonal scales, although global analyses do suggest a link (Cropp et al., 2005). Significantly different responses of natural blooms to long term changes have also been observed (Blain et al., 2007). Changes in global dust deposition predicted by models are also highly variable, as are estimates of future changes in dust emissions, which may be positive or negative (Sect. 5.2).

4. Changes to atmospheric convection and lofting of DMS to the free troposphere could enhance particle nucleation and hence CCN (Shaw et al., 1998). In the GCM simulations of Kloster et al. (2007) global warming caused an overall decrease in the temperature lapse rate in the mid and low latitudes and a reduced lifetime of DMS, although the impact on CCN was not quantified.

5. Levels of surface ultraviolet radiation may affect phytoplankton productivity and the rate of seawater DMS destruction (Larsen, 2005). In a changing climate ultraviolet radiation at the surface may respond to changes in the aerosol loading, cloudiness and/or stratospheric ozone.

\subsubsection{The response of DMS and associated aerosol forc- ing to climate change}

Coupled ocean-atmosphere GCMs have been used to study various combinations of the processes in Fig. 4 (Bopp et al., 2003b; Gabric et al., 2003, 2004, 2005; Vallina et al., 2007a; Kloster et al., 2007; Gunson et al., 2006), but no single study has yet combined them in a complete Earth system model.

Bopp et al. (2003b) used an atmosphere-ocean GCM coupled to a marine biogeochemical scheme to study the response of DMS to a doubling of pre-industrial $\mathrm{CO}_{2}$. The model predicted a $2 \%$ increase in the global DMS flux to the atmosphere but with large spatial heterogeneities (from
$-15 \%$ to $+30 \%$ for the zonal mean). Bopp et al. (2004) prescribed these changes in seawater DMS in an atmospheric GCM and estimated a change in cloud radiative forcing of $-0.05 \mathrm{~W} \mathrm{~m}^{-2}$. However, large regional changes were also predicted, such as a perturbation of up to $-1.5 \mathrm{~W} \mathrm{~m}^{-2}$ in summer between $40^{\circ} \mathrm{S}$ and $50^{\circ} \mathrm{S}$, which could impact the regional climate. A notable feature of their results is a strong response of DMS production to changes in the phytoplankton species composition, most apparent in the sub-Antarctic Pacific. The shift from diatoms to other species more efficient in producing DMS results in a net increase in DMS.

Gunson et al. (2006) used a coupled ocean-atmosphere GCM with an ocean ecosystem model to predict the climate response to changes in DMS. The ecosystem model was used to predict DMS based on an empirical relation with chlorophyll, shortwave radiation, and a nutrient limitation factor (Anderson et al., 2001). Halving DMS emissions caused a net global mean cloud radiative forcing of $+3 \mathrm{~W} \mathrm{~m}^{-2}$ and an increase in surface mean temperature of $1.6 \mathrm{~K}$. Climate warming caused a feedback on the DMS flux, which increased by $2.1 \%$. The negative feedback factor was calculated to be 0.06 which is a small negative feedback in support of the CLAW hypothesis.

Vallina et al. (2007a) used an ocean GCM forced by offline meteorology in a control and a $1.46 \times \mathrm{CO}_{2}$ atmosphere for a 56-year climate warming scenario. Two diagnostic equations defined the DMS response to either mixed layer depth and chlorophyll or solar radiation dose. Their model predicted a very small (1.2\% global mean) increase in DMS flux in response to a net decrease in mixed layer depth. Regional differences were also small (6.3\% at 95th percentile) with maximum changes of $10-15 \%$ in the equatorial Pacific.

Gabric et al. (2001) used a coupled ocean-atmosphere GCM and a mechanistic DMS model driven by sea-surface temperature, wind speed, cloud cover and mixed layer depth. They estimated a 5\% increase in DMS flux from 1960 to $2080\left(\mathrm{CO}_{2}\right.$ tripling $)$ for a region of the Southern Ocean. The main driver was a decrease in the mixed layer depth. They equated this change in DMS to a $-0.3 \mathrm{~W} \mathrm{~m}^{-2}$ radiative perturbation (direct and cloud) and a negative feedback factor of 0.04, similar to Gunson et al. (2006).

Kloster et al. (2007) used a coupled ocean-atmosphere GCM coupled to a plankton dynamics model. Their model accounted for changes in ocean dynamics and mixing in response to climate change. Between 1861-1890 and 20612090 they calculated a global mean $10 \%$ decrease in DMS flux to the atmosphere, resulting in a $3 \%$ decrease in DMS concentration (owing to changes in atmospheric lifetime of DMS). The response of DMS was globally heterogeneous. In particular, decreases in summer seawater DMS of up to $40 \%$ occurred in the Southern Ocean caused by an increase in the summer mixed layer depth and mixing of phytoplankton to depths where photosynthesis is less favorable. This response, which is opposite to previous model results, was driven by changes in wind patterns caused by the poleward shift of the 
storm track. At low and mid-latitudes DMS sea surface concentrations decreased by $\sim 10-20 \%$ due to increased stratification, while at high latitudes DMS concentrations increased due to retreat of sea ice. They find changes in phytoplankton speciation to have only a small effect on DMS production, unlike Bopp et al. (2003b).

The response of global CCN to changes in DMS has been estimated using a global aerosol microphysics model for a present-day and global warming scenario (Woodhouse et al., 2010). In the globally warmed scenario (Vallina et al., 2007b) the largest CCN change was only $0.2 \%$, in the Southern Ocean. They also showed that the changes in DMS flux and CCN concentration between the present day and the global warming scenario were similar to changes caused by interannual variability in windspeed. They concluded that the sensitivity of CCN to potential future changes in DMS flux is very low.

\subsection{Marine primary aerosol}

Marine primary aerosol includes both inorganic and organic components. Both emissions are susceptible to changes due to changes in wind speed, while the organic component may also respond to changes in marine biota, much like DMS.

\subsubsection{Sea salt particles}

It has been known for a long time that sea spray particles are numerous enough to constitute an important source of $\mathrm{CCN}$ at cloud base and that their production rate is wind speed dependent (O'Dowd and Smith, 1993; see Lewis and Schwartz, 2004, for a review). More recent studies have shown that sea spray emissions extend down to a few nanometres (Martensson et al., 2003; Geever et al., 2005; Clarke et al., 2006) and that emission rates depend on both wind speed and sea surface temperature. Microphysical model studies incorporating these latest emission schemes (Caffrey et al., 2006; Pierce and Adams, 2006; Korhonen et al., 2008) suggest that sea spray makes a substantial but highly variable (typically $10 \%$ to $60 \%$ ) contribution to monthly mean regional MBL $\mathrm{CCN}$ concentrations depending on season and supersaturation, a far higher contribution than assumed originally by Shaw (1983).

Given the substantial contribution of sea spray to CCN, the dependence of production rate on temperature and wind speed, and the long term changes in wind speed observed at southern high latitudes (Le Quéré et al., 2007) and predicted by models, the potential exists for regional or global changes in $\mathrm{CCN}$ in response to climate change. For example, Korhonen et al. (2010) used analysed winds and a global aerosol model to show that CCN concentrations are likely to have increased by an average of $22 \%$ between 50 and $65^{\circ} \mathrm{S}$ since the 1980s due to increased sea spray emissions. This change in $\mathrm{CCN}$ caused a summertime radiative forcing at these latitudes of $-0.7 \mathrm{~W} \mathrm{~m}^{-2}$ over two decades, which is compara- ble to the forcing due to increased $\mathrm{CO}_{2}$ over the same period. They argued that the direction and magnitude of future forcing by this mechanism would depend on the recovery of the Antarctic ozone hole, which is partly responsible for the increased wind speeds (e.g., Son et al., 2008).

Penner et al. (2001) found that sea salt emissions may increase in a warmer climate because of the increase in wind speed. However this result was model-dependent, with some climate models predicting an increase in wind speed in 2100 and other models predicting a decrease. Moreover sea-salt emissions were not calculated interactively in these models, and Penner et al. (2001) had to rely on time-averaged wind speeds for their calculations. This may alter the frequency of high wind speeds which are critical to predict the seasalt emission flux. Jones et al. (2007) examined the change in sea-salt aerosols in response to $2 \times \mathrm{CO}_{2}$ forcing in the HadGEM1 climate model coupled to a mixed-layer ocean and sea ice model. In their simulation the wind speed decreases over most of the tropical and mid-latitude oceans but increases at high latitudes. This increase appears to be related to the reduction in sea ice and the decreased roughness length over the open ocean as compared to sea ice. This causes a sizable increase in sea-salt concentration in these areas $(75 \%$ and $51 \%$ increases in sea-salt burdens poleward $60^{\circ} \mathrm{N}$ and $60^{\circ} \mathrm{S}$, respectively) in response to a doubling of $\mathrm{CO}_{2}$. Given that sea salt particles comprise a significant fraction of $\mathrm{CCN}$ concentrations in these regions (e.g., Spracklen et al., 2005), such large changes are likely to cause a large forcing through changes in cloud drop number (Korhonen et al., 2010).

\subsubsection{Marine organic primary and secondary aerosol}

It has been known for some time that the ocean has a layer of surface-active organic material that can be emitted into the atmosphere (Blanchard, 1964) and substantial amounts of particulate organic carbon (OC) have been observed at several marine sites (Novakov et al., 1997; Putaud et al., 2000; Cavalli et al., 2004; O'Dowd et al., 2004; Leck and Bigg, 2005a, b; Pio et al., 2007; Bigg and Leck, 2007; Spracklen et al., 2008c).

The correlation of marine aerosol OC with chlorophyll (O'Dowd et al., 2004, 2008; Spracklen et al., 2008c) and the strong seasonal cycle in OC abundance suggests a biologically driven production mechanism of potential importance to climate. It has been proposed that marine OC has the potential to modify or augment the CLAW mechanism via DMS oxidation (Leck and Bigg, 2007). The marine OC source is highly uncertain with emission estimates ranging from 2 to more than $75 \mathrm{Tg} \mathrm{a}^{-1}$ (Heald et al., 2006b; Roelofs, 2008; Spracklen et al., 2008c; Langmann et al., 2008). Spracklen et al. (2008c) used a combination of new OC observations in remote regions and inverse modeling simulations to suggest a global marine OC source of $\sim 8 \mathrm{Tg} \mathrm{a}^{-1}$, comparable to the global anthropogenic OC source of $5-30 \mathrm{Tg} \mathrm{a}^{-1}$ and the $22.6 \mathrm{Tg} \mathrm{a}^{-1}$ of sulphur emitted as DMS. Based on these 
emissions and the correlation of aerosol OC and chlorophyll it seems likely that marine OC will impact climate, but the effect depends on the relative contribution the OC particles make to CCN alongside sea salt and DMS-derived aerosol.

Model simulations to quantify the contribution to $\mathrm{CCN}$ have not been feasible yet because of our limited understanding of the sources and physical and chemical properties of the marine OC, which is likely to have various and complex biological sources. For example, some studies have detected degradation products of bacteria and viruses in the aerosol (Leck and Bigg, 2005a, b). Other studies suggest that much of the organic material is water-insoluble when emitted from the ocean (Ceburnis et al., 2008), but that SOA of marine origin can also contribute to particle growth (Vaattavorra et al., 2006). Meskhidze and Nenes (2006) suggested that marine isoprene emissions could explain observed correlations between chlorophyll and cloud drop sizes observed by satellite, but a follow-up study (Miller and Yuter, 2008) casts doubt on the correlations. Furthermore, the abundance of atmospheric marine OC is much higher than can be explained in terms of isoprene emissions alone (Spracklen et al., 2008c; Palmer and Shaw, 2005; Arnold et al., 2009), suggesting that primary emissions may dominate (Leck and Bigg, 2007). Observations in the north east Atlantic suggest that approximately $70 \%$ of water-insoluble organic carbon exists at submicron sizes (Cavalli et al., 2004). Such enrichment in small particles, unlike sea salt, suggests a high potential efficiency of the $\mathrm{OC}$ to act as $\mathrm{CCN}$.

Another open question, as with DMS, is how biological processes control the organic aerosol emissions and the extent to which wind speed or other physical processes play a role (Nilsson et al., 2007; O'Dowd et al., 2008). However, with present knowledge on the magnitude of emission and the correlation with chlorophyll, marine organic aerosol needs to be considered as a potentially important component of the climate-ocean-aerosol feedback alongside DMS.

\subsection{Other marine emissions}

There are many other biologically driven species emitted from the ocean that may also affect atmospheric chemistry or climate, such as organohalogens (Carpenter et al., 2003), ammonia (Schlesinger and Hartley, 1992), isoprene (Bonsang et al., 1992; Palmer and Shaw, 2005; Arnold et al., 2009), monoterpenes (Yassaa et al., 2008) and other non-methane hydrocarbons (Guenther et al., 1995). The influence of these emissions on climate has not been quantified, but their potential to influence oxidants and aerosol processes in remote marine regions is plausible and needs to be evaluated. For example, oceanic organohalogens are strong sources of reactive halogen species in the atmosphere, such as the halogen oxide radicals $\mathrm{IO}$ and $\mathrm{BrO}$, which influence tropospheric oxidation processes, DMS chemistry and particle formation in some environments (O'Dowd et al., 2002). These species may strongly control photochemistry of remote ocean re- gions (Read et al., 2008) and impact DMS chemistry and aerosol production.

\subsection{Summary and status of marine aerosol in Earth sys- tem models}

Tables 5 and 6 summarise the likely aerosol-climate feedbacks associated with marine aerosols as well as the priorities for future research and model development. Coupled ocean-atmosphere GCMs have been used to study the impact of climate change on marine DMS and aerosol emissions. These studies point to a weak positive or negative global response of sulphate aerosol to climate change due to increased $\mathrm{CO}_{2}$. Most studies suggest a negative feedback (more aerosol in a warmer climate) driven by multiple factors outlined in Sect. 3.1.2. A positive feedback was predicted by Kloster et al. (2007) due to physical changes to the ocean. Some studies predict large regional changes in aerosol and radiative perturbations as high as $-1.5 \mathrm{~W} \mathrm{~m}^{-2}$, which would be important for regional climate change. The change in marine sea spray aerosol in a future climate depends primarily on wind speed. Increases in wind speed will cause more sea spray and a negative climate feedback, which is so far poorly quantified. The organic content of the small sea spray particles most relevant to climate is very substantial and probably coupled to biological activity. The magnitude and direction of any climate feedback driven by marine biota is currently unknown.

The next stage in model development will involve the coupling of more advanced ocean ecosystem models (e.g., Le Quéré et al., 2005), ocean-atmosphere physical models, and the available global aerosol microphysics models. In parallel, there is considerable scope for evaluation of the sub-models against observations.

The key priority is to improve our understanding of how the physical state of the ocean and atmosphere will change in a future climate, as this ultimately drives DMS production and emission. Large differences in GCM predictions of the impact of climate change on DMS emissions appear to be due in large part to differences in such physical responses. Accurate predictions of changes in sea ice and the effects of changing temperature and wind speed on the mixed layer depth and stratification are essential.

There are several major observational and modeling challenges to understand the environmental factors that govern phytoplankton processes (Boyd, 2002) and DMS emission, which is the basis of CLAW as a climate regulator. As with all components of the CLAW mechanism, it has become clear that DMS production is more complex than previously thought (Archer, 2007). In particular, grazers, viruses and bacteria all play a role in converting DMSP to DMS, but the budget of the various processes remains poorly quantified. Prediction of DMS requires a model of the ecosystem regulation of DMS production (Stefels et al., 2007) and an ecosystem dynamics model to predict the response of the producers 
Table 5. Status of marine DMS-derived aerosol in Earth system models, developments needed, key observations, magnitude of radiative effect in 2100, and the level of scientific understanding.

\begin{tabular}{|c|c|c|c|c|c|c|}
\hline Model status & $\begin{array}{l}\text { Model challenges and } \\
\text { developments }\end{array}$ & Priority & Key observations needed & Priority & $\begin{array}{l}\text { Direction and magni- } \\
\text { tude of feedback by } \\
2100\end{array}$ & LOSU \\
\hline $\begin{array}{l}\text { - Some coupled } \\
\text { studies of the } \\
\text { phytoplankton- } \\
\text { DMS-aerosol-cloud } \\
\text { feedback. }\end{array}$ & $\begin{array}{l}\text { Ocean response to cli- } \\
\text { mate change (mixing, } \\
\text { stratification, nutrients, } \\
\text { etc.) }\end{array}$ & High & $\begin{array}{l}\text { Global marine } \mathrm{CCN} \text {, } \\
\text { DMS, and their seasonal } \\
\text { variability }\end{array}$ & High & \multirow{5}{*}{$\begin{array}{l}\text { - Positive or negative } \\
\text { - Global mean few } \\
\% \text { increase in sulphate } \\
\text { aerosol. } \\
\text { - Forcing regionally } \\
>1 \mathrm{~W} \mathrm{~m}^{-2}\end{array}$} & \multirow[t]{5}{*}{ Poor } \\
\hline \multirow[t]{4}{*}{$\begin{array}{l}\text { - New generation } \\
\text { sub-models of DMS } \\
\text { chemistry, aerosol } \\
\text { dynamics and marine } \\
\text { biota not yet fully } \\
\text { coupled }\end{array}$} & $\begin{array}{l}\text { Ocean biota models to } \\
\text { capture observed plank- } \\
\text { ton dynamics, ocean pro- } \\
\text { ductivity, and seawater } \\
\text { DMS }\end{array}$ & High & $\begin{array}{l}\text { DMS production in re- } \\
\text { gions of sea-ice }\end{array}$ & Medium & & \\
\hline & $\begin{array}{l}\text { DMS production in re- } \\
\text { gion of sea-ice and sea- } \\
\text { ice changes }\end{array}$ & Medium & DMS in coastal regions & Medium & & \\
\hline & $\begin{array}{l}\text { Budget of DMS in the } \\
\text { seawater including de- } \\
\text { struction by UV }\end{array}$ & Medium & & & & \\
\hline & $\begin{array}{l}\text { Evaluated global mod- } \\
\text { els of sulphur-halogen- } \\
\text { oxidant chemistry, in- } \\
\text { cluding multi-phase pro- } \\
\text { cesses }\end{array}$ & Medium & & & & \\
\hline
\end{tabular}

to climate change (e.g., Le Quéré et al., 2005). Models have grown considerably in complexity since the first DMS production models of Gabric et al. (1993) and Lawrence et al. (1993). They are able to reproduce observed chlorophyll and DMS dynamics where they are in phase at high latitudes $\left(>40^{\circ}\right)$ but have failed to capture behavior at low latitudes where high summer DMS concentrations are associated with low chlorophyll - the so-called "summer paradox" (Simo et al., 1999). Recent models incorporating solar radiation dosedependent DMSP production do much better (Vallina et al., 2008). A major challenge for the global models is therefore to reproduce the interannual variability of surface chlorophyll (Le Quéré et al., 2005; Behrenfeld et al., 2006). The predictive skill of these models should be demonstrated in a GCM against observed regional and seasonal variations in plankton and DMS, including the "summer DMS paradox". Such evaluation would give increased confidence in predictions of DMS changes this century.

The impact of iron deposited in dust on DMS production is poorly understood. While an attempt can be made to simulate it in Earth system models, fundamental work is needed on iron speciation in dust, transformation in the atmosphere, and availability to biota (Sect. 5.2.2).
Prediction of the response of climate-relevant aerosol particles to perturbed DMS emissions requires a global model that couples atmospheric chemistry and aerosol microphysics. The chemistry of DMS is more complex than originally appreciated when the CLAW hypothesis was proposed, and the details appear to be important for quantifying the production of aerosol (von Glasow, 2007; Barnes et al., 2006; Lucas and Prinn, 2005). Models need to take account of several oxidants $\left(\mathrm{OH}, \mathrm{NO}_{3}, \mathrm{BrO}, \mathrm{O}_{3}\right)$ as well as heterogeneous chemistry on sea spray particles (Boucher et al., 2003; von Glasow and Crutzen, 2004). There are large differences in predictions among gas phase chemistry schemes of different complexity, which may be as much as an order of magnitude for $\mathrm{H}_{2} \mathrm{SO}_{4}$ in some regions (Lucas and Prinn, 2005). Although the ability of simplified reaction schemes to capture regional and seasonal variability in aerosol production from DMS and the response to climate change is at present questionable, the more complex models remain too computationally demanding for Earth system models. Thus the first major challenge is to demonstrate the explanatory power of complex chemical schemes against observations and the second challenge is to develop accurate simpler schemes that are fast enough to run on centennial timescales. 
Table 6. Status of marine primary aerosol in Earth system models, developments needed, key observations, magnitude of radiative effect in 2100, and the level of scientific understanding.

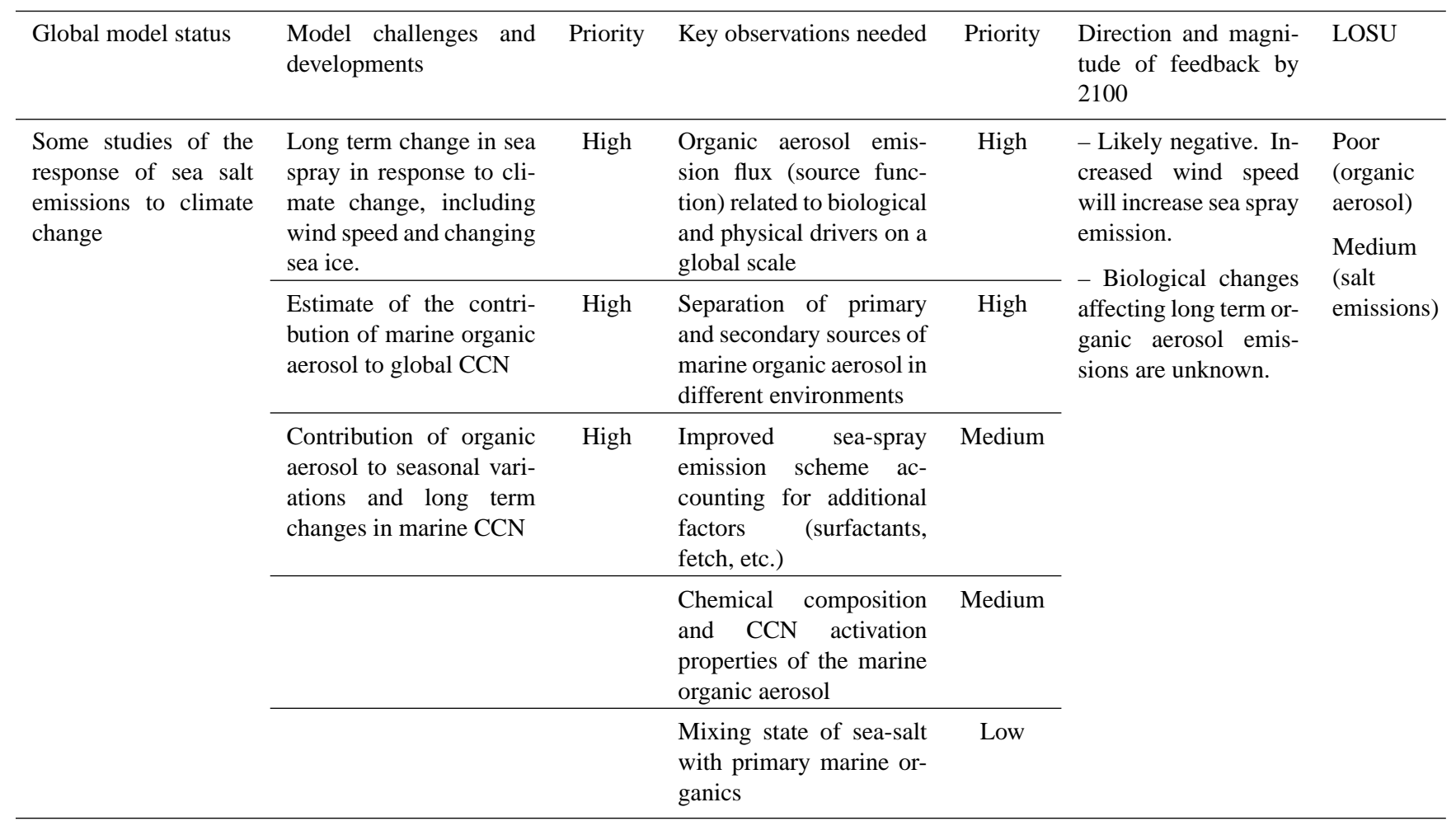

Many global models now include microphysical schemes sufficient to simulate the response of $\mathrm{CCN}$ to changes in DMS and sea spray (e.g., Korhonen et al., 2008, 2010; Kloster et al., 2008; Woodhouse et al., 2010), and these models are suitable for inclusion in Earth system models. A major challenge is to evaluate these aerosol models against observations of DMS and CCN on seasonal and interannual timescales in different regions. However, a substantial limitation is the lack of observed DMS emissions (which need to cover very wide regions around the aerosol observations (Woodhouse et al., 2008)), as well as the lack of long-term reliable datasets of CCN. Satellite observations of CCN, cloud drop size and chlorophyll (Meskhidze and Nenes, 2006; Vallina et al., 2007b) are potentially valuable in aerosol model assessment, but need to be carefully evaluated against in situ observations if they are to be used quantitatively. It is important to note model predictions of the change in DMS emission in a future climate do not lead straightforwardly to changes in $\mathrm{CCN}$ because of the non-linear processes linking $\mathrm{H}_{2} \mathrm{SO}_{4}$ production and particle nucleation (Korhonen et al., 2009; Woodhouse et al., 2008).

Our understanding of marine aerosol and the impact on climate has some large and fundamental gaps. The substantial organic component of sub-micron sea spray aerosol has been a significant discovery in recent years (Sect. 3.2.2) but an understanding of the production mechanisms, spatial and temporal variability and $\mathrm{CCN}$ properties prohibits inclusion in global models at present. There is a need for more extensive global observations coupled with process-based models to quantify the organic fraction of sea spray and the factors that control it. Long term observations of aerosol microphysical and chemical properties in remote oceanic regions are very rare and insufficient to quantify long term trends in sea spray. Air-sea gas and aerosol exchange is very uncertain ( $>$ factor 2) and only takes account of wind speed, neglecting currently poorly understood factors such as surface surfactants, fetch and temperature. Given the very large uncertainties in air-sea exchange rates, the impact of long term changes in these factors should not be ignored. Also, given the current resolution of climate models, the sub-grid scale variability in wind speed may be important to simulate airsea exchange and parametrisations of gustiness need to be introduced in the models (Morcrette et al., 2008).

\section{Stratospheric and volcanic aerosols}

There is a thin layer of aerosols in the stratosphere, between the tropopause and $30 \mathrm{~km}$, known as the Junge layer. 
For a long time stratospheric aerosols were thought of being mostly composed of sulphuric acid of submicron size. However, it is realized now that organic aerosols may play a role as well, at least in the lowest $2 \mathrm{~km}$ of the stratosphere (Murphy et al., 1998). The Junge layer is partly sustained by natural emissions of carbonyl sulphide (OCS) which is produced through biogenic processes. OCS is relatively stable in the troposphere and can reach the stratosphere where it is photochemically broken down, eventually resulting in the formation of sulphuric acid droplets. Sulphur dioxide is also transported through the tropopause but efficient oxidation and scavenging in the troposphere reduces its concentration. Models show that OCS is the main contributor to stratospheric aerosol above $25 \mathrm{~km}$ and $\mathrm{SO}_{2}$ plays a larger role below (Weisenstein et al., 2006). Despite its short lifetime, there could be a small contribution from DMS to the Junge layer as DMS is not scavenged; however the contribution is likely only a few percent. Finally some VOC are longlived and can be oxidized in the stratosphere into semivolatile species that can condense into SOA.

In background conditions (i.e. in the absence of large volcanic eruptions), the Junge layer is so thin (aerosol optical depth smaller than 0.005 at $550 \mathrm{~nm}$ ) that it is hard to imagine that background stratospheric aerosols can play a significant role in climate feedbacks.

Explosive volcanic eruptions can inject $\mathrm{SO}_{2}$ directly into the stratosphere where it is oxidised into sulphuric acid. However most volcanic plumes do not penetrate into the stratosphere and only a small number of eruptions have a significant impact on the Junge layer. The most recent examples are the 1982 El Chichón and the 1991 Mt Pinatubo eruptions. The stratospheric aerosol layer was perturbed for several years following these eruptions, with significant impacts on climate. In particular surface air temperatures cooled by up to $2 \mathrm{~K}$ over the Northern Hemisphere continents in the summer following the Mt Pinatubo eruption (Robock, 2002; Soden et al., 2002) and there is evidence that vegetation and the global carbon cycle have also responded to both the global cooling and the increase in diffuse solar radiation at the surface (Gu et al., 2003). By altering levels of surface ultraviolet radiation, significant perturbations of stratospheric aerosols can also impact aquatic and terrestrial ecosystems (Larsen, 2005; Caldwell et al., 2007; Häder et al., 2007).

Flood lava eruptions can also have a dramatic effect on the environment and affect the troposphere and stratosphere (Thordarson and Self, 2003). The 1783-1784 Laki flood lava eruption in Iceland emitted $\sim 122 \mathrm{Tg} \mathrm{SO}_{2}$ into the atmosphere. The environmental impacts were widespread, including extreme pollution and crop damage, possible high latitude cooling of around $-1.3 \mathrm{~K}$ that lasted for 2-3 years, and wider impacts on the African and Indian Monsoons (Oman et al., 2006). Eruptions of Laki magnitude have occurred in the recent past in Iceland and will occur again (Thordarson and Larsen, 2007). The impact on the biosphere through acid deposition and changes in direct and diffuse radiation
(Sect. 2.4) are likely to be substantial but are poorly understood.

Although climate change is not thought to affect the intensity or the frequency of large volcanic eruption, it is conceivable that climate change will affect the fate of stratospheric aerosols after large volcanic eruptions, thus modulating the climate impact of stratospheric volcanic aerosols. The most likely way climate change can affect stratospheric aerosols is through changes in stratospheric transport and mixing. It has been shown that climate change will enhance the mass exchange between the troposphere and the stratosphere (Butchart and Scaife, 2001). In an intercomparison study Butchart et al. (2006) showed that all the models consistently predict an increase in the mass exchange rate in response to growing greenhouse gas concentrations, irrespective of whether or not the model includes interactive ozone chemistry. The mean trend is $11 \mathrm{kt} \mathrm{s}^{-1} \mathrm{a}^{-1}$, or about $2 \%$ per decade, but varies considerably between models. In all but one of the models the increase in mass exchange occurs throughout the year though, generally, the trend is larger during the boreal winter. Garcia and Randel (2008) showed that in their model the circulation strengthens as a result of increased wave driving in the subtropical lower stratosphere, which in turn occurs because of enhanced propagation and dissipation of waves in this region. Enhanced wave propagation is due to changes in tropospheric and lower-stratospheric zonal-mean winds, which become more westerly.

The increase in the Brewer-Dobson circulation means a shorter lifetime for stratospheric aerosols following large volcanic eruptions in the 21 st century. This would shorten the cooling period and reduce the associated terrestrial carbon uptake experienced after such eruptions.

\section{Dust aerosol}

\subsection{The impact of dust aerosol on climate}

Dust particles interact with solar as well as terrestrial radiation. Over the cloud-free ocean the net direct radiative forcing at the top of the atmosphere (ToA) due to dust is negative due to increased shortwave albedo, which dominates over the longwave effects. In contrast, dust reduces the planetary albedo over bright surfaces (e.g., snow and ice, some deserts) and has different effects above and below bright clouds. The magnitude of all these effects depends strongly on particle size, refractive index and the altitude of dust layers (Liao and Seinfeld, 1998; Arimoto et al., 2001). The composition of dust is especially important in determining the longwave effect (Sokolik et al., 1998; Highwood et al., 2003) since refractive indices in the infrared vary considerably between dusts from different source regions. The net direct radiative impact of dust is a combination of the shortwave and longwave effects and can be positive or negative. 


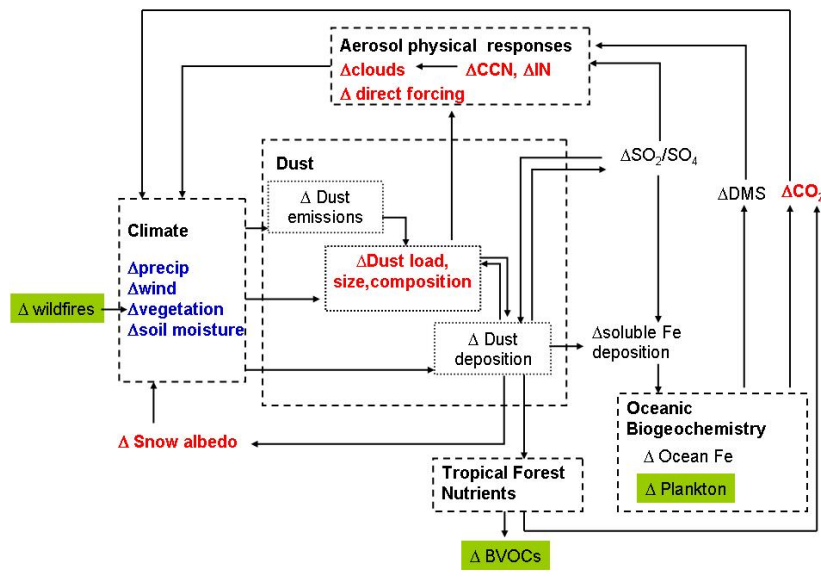

Fig. 5. Possible feedbacks involving dust. Climate change and anthropogenic drivers are indicated in blue, processes in black, and impacts in red.

Estimates of the global mean radiative effect of dust are very uncertain, and typically vary between -0.7 and $+0.5 \mathrm{~W} \mathrm{~m}^{-2}$ at the top of the atmosphere and between -0.82 and $-1.92 \mathrm{~W} \mathrm{~m}^{-2}$ at the surface (Balkanski et al., 2007; Myhre and Stordal, 2001; Tegen et al., 1996; Woodward, 2001). Dust outbreaks result in a cooler surface ocean, thus affecting circulation patterns with potential regional weather and climate feedbacks (Miller and Tegen, 1998).

The accumulation of soluble material during transport as a result of heterogeneous chemistry enables dust particles to act as giant $\mathrm{CCN}$ and activate to cloud droplets with the potential to affect the climate through aerosol indirect effects (Levin et al., 1996). Dust particles may play a role in suppressing rainfall via the aerosol second indirect effect (Rosenfeld et al., 2001) but have also been suggested to enhance precipitation by acting as giant CCN (Feingold et al., 1999; Posselt and Lohmann, 2008) and ice nuclei (DeMott et al., 2003; Hoose et al., 2009). Impacts of Saharan dust on the development of tropical cyclones have also been proposed through the effects of $\mathrm{CCN}$ and giant $\mathrm{CCN}$ (Zhang et al., 2007b).

Dust can also have other indirect effects on climate. For instance, Lee et al. (2008) and Manktelow et al. (2010) show that in dusty regions, $\mathrm{CCN}$ concentrations can be reduced by $10-20 \%$ due to particles providing a condensation sink for sulphuric acid vapor and a coagulation sink for ultrafine particles. Also, increased dust deposition on snow can reduce surface albedo leading to enhanced snow-melt and feedbacks on regional climate (Krinner et al., 2006).

Mineral dust aerosol also plays a key role in the Earth's climate system by providing iron and other nutrients to marine phytoplankton after atmosphere to ocean deposition. Jickells et al. (2005) describe how dust deposition can alleviate nutrient limitation to marine phytoplankton, linking dust emissions, ocean biogeochemistry and climate.

\subsection{Climate controls on dust and feedback processes}

Wind speed, soil moisture and vegetation cover are climatedriven variables that strongly affect dust emission fluxes, size distribution and mineralogical composition and hence, indirectly, control dust transport, deposition and radiative effects. Transport is also controlled by the atmospheric circulation and wet deposition by precipitation. There is, consequently, clear potential for feedbacks involving dust associated with a changing climate. However, as in the case of emissions of biomass burning aerosols from wildfires, there are both natural and anthropogenic factors governing dust emissions (Moulin and Chiapello, 2006). The attribution of changing dust emissions to natural or human causes is very uncertain for this reason and also because, unlike for purely anthropogenic species, the choice of a base time to define natural emissions is essentially arbitrary.

Some early studies (e.g., Tegen and Fung, 1995) found human influences to have increased dust emissions directly via changes in land use by as much as $20-50 \%$ (Tegen et al., 1996; Sokolik and Toon, 1996; Moulin and Ciapello, 2006). However, some studies find the contribution of dust from currently cultivated land to total dust load to be less than $10 \%$ (e.g., Tegen et al., 2004; Prospero et al., 2002). Elevated $\mathrm{CO}_{2}$ concentrations may result in changes in the extent of desert regions in future, though the direction of such change is currently uncertain (Cox et al., 2000; Harrison et al., 2001). The combined role of climate and human intervention in controlling dust emissions makes predictions of future dust emissions unclear. Studies of the effects of anthropogenic climate change on dust loadings (neglecting land use changes) give a wide range of results from large increases (e.g., Woodward et al., 2005, find a factor of 3 increase in 2100) to large decreases (e.g., Mahowald and Luo, 2003, and Mahowald et al., 2006 , find a $60 \%$ decrease under double $\mathrm{CO}_{2}$ concentration), to moderate $(\sim 10$ to $-20 \%)$ increases/decreases (e.g. Tegen et al., 2004). The large range reflects different responses and couplings of the climate and vegetation models used.

\subsubsection{Interaction with the hydrological cycle}

There is evidence that major dust sources tend to be located in topographic lows containing alluvial or aeolian sediments or ephemeral lakes (Prospero et al., 2002; Tegen et al., 2002; Washington et al., 2003). Some of these sources are supply limited and therefore dependent on events such as flooding to provide a source of erodible material for enhanced dust emissions (e.g., Bullard et al., 2008; Niemeyer et al., 1999; Bryant et al., 2007). Future changes in frequency of high rainfall events are likely to affect activation of such sources.

Atmospheric dust concentration measurements made routinely at Barbados since 1965 show a four-fold increase since the 1960s (Prospero and Lamb, 2003). This long-term record has been shown to have a significant correlation with drought occurrence in the Soudano-Sahel region and with 
dust-event frequency from Mali visibility records (Mbourou et al., 1997). However, global models have struggled to replicate the observed dust record, and the relative contributions of changes in source strength and transport efficiency are unclear (Mahowald et al., 2002).

\subsubsection{Biogeochemical effects}

It has been proposed that the $50 \mathrm{Tg}$ of Saharan dust deposited annually to the Amazon basin (Kaufman et al., 2005) is a significant source of nutrients (Swap et al., 1992). Boy and Wilcke (2008) demonstrated that base-metal deposition at an Amazonian forest site was dominated by long-range transport of Saharan dust. The transport and deposition of Saharan dust to the Amazon is linked to the ENSO cycle and is therefore susceptible to changes in climate (Boy and Wilcke, 2008). Dust is therefore a potentially important, but poorly quantified, driver in the carbon cycle of the Amazon region so future changes in dust could have an indirect feedback on climate.

Likewise, Jickells et al. (2005) describe how dust deposition can provide nutrients to oceanic phytoplankton, linking dust emissions, ocean biogeochemistry, the carbon cycle and climate. Martin et al. (1990) hypothesized that high dust loadings during glacial periods would provide more nutrients to the phytoplankton population thereby enhancing primary productivity and oceanic $\mathrm{CO}_{2}$ uptake, which could explain part of the glacial-interglacial difference in atmospheric $\mathrm{CO}_{2}$ levels. A combination of field experiments and modeling (Watson et al., 2000; Bopp et al., 2003a) and analysis of sedimentary records (Kohfeld et al., 2005) suggests that when a glaciation starts, increases in the dust supply of iron to the ocean could drive up to half of the decrease in atmospheric $\mathrm{CO}_{2}$. While there is a reasonable amount of evidence for a long term and substantial effect of changes in dust on $\mathrm{CO}_{2}$ uptake or DMS emission by the oceans in past climates, there is still little observational or modeling evidence for how such feedbacks could operate in the modern atmosphere or in a warmer climate. However, studies have found strong correlations between simulated iron deposition and satellite chlorophyll (Erickson et al., 2003) and observations of net community production (Cassar et al., 2007) in the Southern Ocean suggesting aeolian dust deposition has an important role for present-day ocean biogeochemistry. Cropp et al. (2005) also found strong correlation between satellite-derived chlorophyll and aerosol optical depth, consistent with dust deposition enhancing the productivity of marine biota. It is also possible that changes in dust deposition can modulate the DMS-sulphate-cloud albedo feedback discussed in Sect. 3.1.

\subsubsection{Dust-chemistry interactions}

Dust particles can react with acids during transport and become coated with soluble material (Usher et al., 2002; Un- derwood et al., 2001; Dentener et al., 1996). Such dust chemistry has been shown to reduce the particle lifetime (e.g., Fan et al., 2004) and hence affect dust burden, radiative forcing and deposition to the oceans. As well as enabling dust particles to act as $\mathrm{CCN}$, reactive uptake of acids also increases the solubility of iron, making it more available to the phytoplankton in the ocean (Fan et al., 2006). These observations have led to the suggestion that changes in anthropogenic $\mathrm{SO}_{2}$ emissions over East Asia (for example) may affect carbon fixation in High Nutrient Low Chlorophyll regions of the ocean via atmospheric dust deposition (Meskidhze et al., 2003) - see Sect. 5.2.2. A further effect may be to increase the $\mathrm{CCN}$ activity of dust particles, thereby impacting rainfall (Levin et al., 1996).

The reactive uptake of gases on dust depends strongly on dust mineralogy. Particles with significant carbonate content (e.g. containing calcite, dolomite) are alkaline and hence strongly reactive in the presence of atmospheric acids (e.g. Claquin et al., 1999). Bauer and Koch (2005) found that interaction between sulphate and dust would reduce the sulphate direct forcing from -0.25 to $-0.18 \mathrm{~W} \mathrm{~m}^{-2}$ when heterogeneous oxidation of $\mathrm{SO}_{2}$ is included, as a result of a reduced concentration of externally mixed sulphate. Dentener et al. (1996) found that 50-70\% of global sulphate formation is associated with dust, however a more recent study evaluated against observations suggests a $2 \%$ effect even in a dust storm because changes in fine and coarse dust essentially compensate (Manktelow et al., 2010). A significant fraction of nitric acid is also likely to be associated with dust (Dentener et al., 1996).

Uptake of other gases to dust particles and the impact on photolysis rates can also affect oxidant concentrations and atmospheric chemistry (e.g. Dentener et al., 1996; Bian and Zender, 2003; Liao et al., 2003).

\subsection{Summary and status of dust in Earth system models}

Table 7 summarises the likely aerosol-climate feedback associated with dust aerosol as well as the priorities for future research and model development. Models predict that dust could increase or decrease substantially in a future climate. The net top of the atmosphere dust aerosol radiative forcing caused by these changes would therefore also be positive or negative. Woodward et al. (2005) estimated the largest increase in dust by 2100 (a factor 3) leading to a factor 5 increase in dust direct radiative perturbation at the top of the atmosphere compared to 2000 (in their model, the positive forcing increased from 0.04 to $0.21 \mathrm{~W} \mathrm{~m}^{-2}$ ).

Studies of the feedbacks associated with dust are at an early stage. Development is needed in several subcomponents of Earth system models, including the land surface, vegetation and ocean biogeochemical as well as atmospheric dust schemes.

Dust modeling has progressed considerably over the last two decades, but there are still many major uncertainties 
Table 7. Status of dust aerosol in Earth system models, developments needed, key observations, magnitude of radiative effect in 2100 , and the level of scientific understanding.

\begin{tabular}{|c|c|c|c|c|c|c|}
\hline Global model status & $\begin{array}{l}\text { Model challenges and } \\
\text { developments }\end{array}$ & Priority & Key observations needed & Priority & $\begin{array}{l}\text { Direction and magni- } \\
\text { tude of feedback by } \\
2100\end{array}$ & LOSU \\
\hline \multirow{4}{*}{$\begin{array}{l}\text { - A few studies of the } \\
\text { dust response in cli- } \\
\text { mate change simula- } \\
\text { tions } \\
\text { - Limited constraints } \\
\text { on modelled long } \\
\text { term changes from } \\
\text { observations } \\
\text { - Very few studies } \\
\text { of wider Earth system } \\
\text { interactions }\end{array}$} & $\begin{array}{l}\text { Allow soil mineralogy } \\
\text { to affect dust properties } \\
\text { (iron content and specia- } \\
\text { tion, refractive index) }\end{array}$ & Medium & $\begin{array}{l}\text { Global observational cli- } \\
\text { matology of soil mois- } \\
\text { ture }\end{array}$ & High & \multirow{4}{*}{$\begin{array}{l}\text { - Possible large pos- } \\
\text { itive (up to factor } 3) \\
\text { or negative }(-60 \%) \\
\text { change in dust bur- } \\
\text { den (latter for doubled } \\
\mathrm{CO}_{2} \text { ). } \\
\text { - Positive or negative } \\
\text { aerosol forcing. } \\
\text { - Indirect feedbacks } \\
\text { through changes in } \\
\text { ice nuclei concentra- } \\
\text { tion and nutrient sup- } \\
\text { ply to terrestrial and } \\
\text { marine system possi- } \\
\text { ble }\end{array}$} & \multirow{4}{*}{ Very Poo } \\
\hline & $\begin{array}{l}\text { Better characterization } \\
\text { of soil wetness and } \\
\text { vegetation response to } \\
\text { climate change. }\end{array}$ & Medium & $\begin{array}{l}\text { Ice nucleating ability of } \\
\text { dust as a function of } \\
\text { mineralogy and amount } \\
\text { of mixture, and observa- } \\
\text { tions of effects on clouds }\end{array}$ & High & & \\
\hline & $\begin{array}{l}\text { Improved dust emission } \\
\text { schemes }\end{array}$ & Medium & $\begin{array}{l}\text { Refractive indices of } \\
\text { dust from different } \\
\text { source regions }\end{array}$ & Medium & & \\
\hline & $\begin{array}{l}\text { Response of ocean biota } \\
\text { models to iron and other } \\
\text { nutrients. }\end{array}$ & Medium & $\begin{array}{l}\text { Iron speciation, } \\
\text { haematite content } \\
\text { and geomorphology of } \\
\text { soils, including iron } \\
\text { bioavailability }\end{array}$ & Medium & & \\
\hline
\end{tabular}

associated with all aspects of the dust lifecycle. Basic emission processes are not yet fully understood and a range of emission schemes are used which each seem to capture some but not all of the details of the deflation process (e.g. Marticorena and Bergametti, 1995; Alfaro and Gomes, 2001). The widely used saltation models do not apply to areas where other processes such as abrasion are dominant, and indeed may not apply to the largest single dust source found in the Bodele depression (Todd et al., 2007). The effects of crusting, soluble salts in the soil, supply limitation and resuspension are all generally ignored. Further research on these processes is required, to allow them to be parametrized in emission models, together with the behavior of different geomorphic types and better characterization of sub-grid-scale wind variability and soil properties. New models representing the response of vegetation to climate change are also needed, as this is a major controlling factor for dust emissions, especially in arid and semi-arid areas. Global datasets of surface properties including geomorphology, soil size distribution and mineralogical composition would aid the development of emission schemes significantly. Improved understanding and representation of the relation between horizontal and vertical dust fluxes are fundamental requirements. The use of satellite data to constrain emissions (e.g. through the use of preferential source areas) has allowed significant improvement in the identification of source regions (e.g., Prospero et al., 2002; Schepanski et al., 2007) and the agreement of models with observed optical depths (Zender et al., 2003). However in order to simulate the various feedbacks on dust production that may be influenced by climate change, more of the basic production processes will need to be represented explicitly in models.

In the atmosphere, further observational data for model evaluation is required. A particular challenge is the provision of long-term data on a global scale, which are needed due to the strong spatial and temporal variability of dust 
concentration, size distribution and hence radiative effects. Direct measurements of dust concentrations are needed as well as optical depths, to allow both modeled concentrations and parametrized radiative properties to be assessed. Improved understanding and parametrizations of wet and dry deposition processes are also required (Jung and Shao, 2006; Petroff et al., 2008). The representation of radiative properties is another area where development would be useful. Balkanski et al. (2007) have shown that the haematite content is critical for a correct simulation of atmospheric absorption by African dust. On a global scale, haematite in potentially arid soil types can vary at least from 0 to $7 \%$ by mass (Claquin et al., 1999), so this factor will have to be included if local dust forcings are to be calculated correctly (Krinner et al., 2006). In the longwave, dust refractive indices are even more variable between different source areas than in the shortwave, and the effect of this will also have to be addressed.

Better characterization of soil particle size is essential because it can substantially alter the long range transport to remote oceans (Grini and Zender, 2002) as well as affecting the radiative impact of the dust and the bio-availability of its iron content to plankton. This requires improvements to the modeling of emission, transport and deposition, all of which are size-dependent, as well as enhanced surface soil datasets. Changes in dust chemistry during transport may be important for iron and phosphorous availability in the oceans, although more fundamental research is needed (e.g., Fan et al., 2006).

In the ocean, present global biogeochemical models do not reproduce the interannual variability of surface chlorophyll as observed by the SeaWiF Satellite (Le Quéré et al., 2005), or the interannual variability of $\mathrm{CO}_{2}$ exchange with the atmosphere as produced by atmospheric inversions (Le Quéré et al., 2007). Accurate modeling of the response of marine ecosystems and plankton speciation to changes in iron input will require a representation of plankton functional types.

\section{Summary}

\subsection{Direction and magnitude of aerosol feedbacks}

Figure 6 summarises the possible global mean aerosol radiative perturbations associated climate-induced changes in wildfires, biogenic SOA, dust and marine DMS in 2100 relative to present day conditions (see the caption for a description of how the perturbations were estimated). The estimates refer only to the global mean direct radiative perturbation due to changes in the atmospheric burden of the emitted aerosols (except for DMS where the calculations also include changes in cloud albedo). These estimates derive largely from climate models or offline calculations rather than fully coupled Earth system models, and therefore neglect the wide range of secondary effects of changes in these aerosols (for example, effects on the carbon cycle) as well as coupled aerosol effects

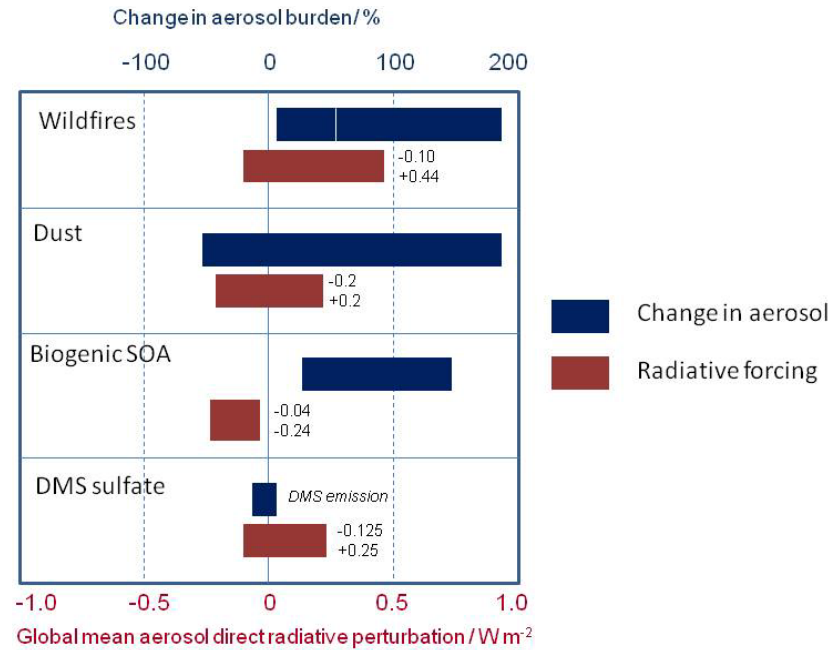

Fig. 6. Aerosol radiative perturbations due to climate-induced changes in natural aerosol between the present day and 2100. Values refer to the change in aerosol abundance between today and 2100 and not the radiative effect of the total burden. For wildfires only the direct radiative perturbation is shown. We assume that the change in wildfire aerosol emissions scales with the area burned. Changes in wildfire area burned were calculated from the studies reviewed by Flannigan et al. (2009) (mean 100\%, minimum $12 \%$, maximum $475 \%$ ). We estimate the change in organic carbon concentrations (mean 42\%, min 5\%, max 200\%) using the ratio of 2.37 between the change in emissions and change in surface organic carbon concentrations from Spracklen et al. (2009). Wildfire global mean direct radiative forcing was then estimated by multiplying these fractional changes in aerosol by the model estimates of current direct forcing $\left(-0.05\right.$ to $0.22 \mathrm{~W} \mathrm{~m}^{-2}$, Forster et al., 2007; Sect. 2.3.1). For dust direct radiative forcing, we base our estimate on two studies of dust changes due to climate but ignoring land use changes: Woodward et al. (2005) and Mahowald et al. (2006). Woodward et al. (2005) estimate a factor 3 increase in dust loading and a factor 5 increase in direct forcing by 2100 (from 0.04 to $0.21 \mathrm{~W} \mathrm{~m}^{-2}$ ). Mahowald et al. (2006) estimate a $60 \%$ decrease in dust load corresponding to a $+0.14 \mathrm{~W} \mathrm{~m}^{-2}$ forcing in a $2 \times \mathrm{CO}_{2} \mathrm{cli}-$ mate. These studies predict opposite responses of the dust loading but also opposite direction of forcing for a given change in dust. Thus, we assume that comparable negative forcings of around $0.2 \mathrm{~W} \mathrm{~m}^{-2}$ are plausible. Changes in biogenic SOA and the associated direct radiative forcing are based on estimates summarised in Sect. 2.5 (a 25 to $150 \%$ increase in aerosol burden and global mean forcing of -0.04 to $-0.24 \mathrm{~W} \mathrm{~m}^{-2}$ ). For the marine aerosol system the radiative forcing feedback due to changes in DMS can be estimated from the model studies summarised in Sect. 3.1.3. Changes in DMS flux in various future climate scenarios range from $-10 \%$ to $+5 \%$. Bopp et al. (2004) estimated a global mean direct and indirect aerosol forcing of $-0.05 \mathrm{~W} \mathrm{~m}^{-2}$ for a $2 \%$ increase in DMS flux (Bopp et al., 2003b) in a $2 \times \mathrm{CO}_{2}$ scenario. Using the range of estimated changes in DMS flux and the forcing per percentage change in DMS emission from Bopp et al. (2004) we suggest that the 2100 direct and indirect aerosol forcing due to changes in DMS emission lies between -0.125 and $+0.25 \mathrm{~W} \mathrm{~m}^{-2}$. 
(such as the effect of dust nutrients on DMS emissions). Also not shown are the potentially large regional forcings, or the indirect effects on clouds. For biogenic SOA alone, we estimated (Sect. 2.1.4) a forest-wide cloud albedo radiative perturbation between -0.6 and $-2.7 \mathrm{~W} \mathrm{~m}^{-2}$ (corresponding to a global mean perturbation of up to $-0.3 \mathrm{~W} \mathrm{~m}^{-2}$. The restriction of the estimates in Fig. 6 to direct radiative perturbations is nevertheless consistent with the state of the science of aerosol interactions in the Earth system.

Our review of available studies of aerosol interactions with the Earth system suggests that there is the potential for substantial feedbacks on the climate. Future climate change is likely to have significant effects on the natural environment and hence the physical and biological systems that generate aerosol. The direct radiative effect of changes in the atmospheric burden of natural aerosols by the end of the century lies between about -0.8 and $+0.15 \mathrm{~W} \mathrm{~m}^{-2}$. There is ambiguity about the sign of the individual radiative perturbations due to DMS-derived sulphate, wildfires and dust, but the increase in biogenic SOA is likely to cause a negative forcing. The combined effect of changes in natural aerosols, if their effects add in the same direction, could cause a global mean direct radiative perturbation approaching $\pm 1 \mathrm{~W} \mathrm{~m}^{-2}$. Currently it is not possible to estimate the cloud indirect effects, but for biogenic SOA alone we estimate a radiative effect at least as large as the direct effect.

The terrestrial biosphere is a very large source of submicron SOA mass in the present atmosphere and most observational and modeling studies suggest this source will increase substantially, primarily due to increases in temperature and changes in vegetation (Sect. 2.1). There is the potential for a maximum of about $-0.24 \mathrm{~W} \mathrm{~m}^{-2}$ global mean direct radiative perturbation due to additional biogenic SOA in the atmosphere by mid to late century (compared with a present-day anthropogenic direct aerosol forcing of -0.1 to $-0.8 \mathrm{~W} \mathrm{~m}^{-2}$ ). Radiative perturbations of several Watts per square metre have been estimated or can be inferred close to natural aerosol sources, such as over forests.

The net radiative effect of changes in wildfires is ambiguous. Several factors are important but have not been studied together in Earth system models or observations. Fires emit absorbing aerosol that has either a positive or negative direct radiative effect (Sect. 2.3.1); deposition of absorbing material on snow accelerates melting; the local radiative effect is a combination of changes in biophysical effects (albedo, hydrology), carbon sequestration, and changes in biogenic secondary aerosol formation (Spracklen et al., 2008b). Despite the complex couplings and competing effects, regional studies suggest increases in wildfire emissions of $>100 \%$ by 2050 and associated increases in aerosol organic carbon of $>40 \%$. Based on these changes and previous estimates of the wildfire aerosol forcing it is possible that wildfires will cause a global mean radiative perturbation of greater than $0.4 \mathrm{~W} \mathrm{~m}^{-2}$ by 2100 .
In the marine system, the effect of climate change on DMS emissions and atmospheric sulphate aerosol also remains ambiguous. Global models suggest changes in DMS emissions and/or aerosol sulphate of a few percent and a forcing of up to $0.25 \mathrm{~W} \mathrm{~m}^{-2}$. Regionally the forcing due to changes in cloud properties may be $>1 \mathrm{~W} \mathrm{~m}^{-2}$, which would impact regional climate. However, large gaps remain in the ability of models to capture interannual changes in ocean productivity (Sect. 3.1.2), so confidence in models of DMS is probably low. The effects of changes in primary marine aerosol (sea salt and organic material) are potentially large and could conceivably exceed the impact of DMS, although more fundamental research is needed to estimate the effects.

\subsection{Research requirements}

\subsubsection{Key uncertainties}

The main open questions and gaps in our knowledge have been addressed in Sects. 2.5, 3.4 and 5.3 for each aerosol system. An important finding of this review is that the uncertainties in climate drivers are a very large component of the overall uncertainty in aerosol changes. For example, in marine regions the DMS emissions depend on changes in the mixed layer depth, wind speed, ocean surface temperature and sea ice extent, none of which can yet be confidently predicted on regional scales over the next century. For dust, it is changes in the hydrological cycle, vegetation and wind speed that will largely determine future dust levels. Some components of the Earth system have a substantial impact on the emissions of several important aerosols. For example, better quantification of biogenic secondary organic aerosols, wildfires and dust will require an improved understanding of the response of vegetation to climate change. Thus, better quantification of aerosol feedbacks requires improvements in several physical and biological components of Earth system models in parallel with improvements in aerosol processes themselves.

Most of the feedbacks operate through the effect of climate change on the rate of emission of natural aerosols, leading to future changes in aerosol burden and properties, with associated effects on direct and indirect radiative forcing. Enough is known about the likely changes in emissions to estimate likely future forcings (Fig. 6). However, the indirect feedbacks involving the impacts of aerosol on other components of the Earth system, such as the carbon cycle or the cryosphere, are much less well defined. For example, dust is in this latter category since it is an important source of iron for phytoplankton, which has a critical effect on the ocean carbon cycle.

Some processes reviewed here have only recently been studied and much more needs to be done before we can even begin to estimate likely couplings in the Earth system. A good example is primary organic aerosol emissions from 
the ocean and the terrestrial biosphere. These have the potential to exert a large feedback effect on climate.

\subsubsection{Measurements}

Both field and laboratory measurements can and have been applied to study feedbacks and processes behind them. Process level understanding can be achieved using laboratory experiments, continuous comprehensive field observations and process models. To utilise the process understanding in global models, satellite retrievals, airborne experiments and long term continuous ground-based experimental monitoring networks are needed.

The coupling of natural aerosol emissions and processes with the functioning of physical and biological systems makes continuous comprehensive measurements particularly useful. A good example of comprehensive measurements is the SMEAR II station in the Finnish boreal forest (Hari and Kulmala, 2005). The dataset enables direct comparison of different feedbacks; for example how biogenic aerosol production is related to $\mathrm{CO}_{2}$ concentration and fluxes as well as changes in temperature, cloudiness and rain. A network of such stations provides a rich dataset for evaluation of aerosolEarth system interactions on regional scales (Kulmala et al., 2008, 2009). A good example of the use of long data sets from several stations is the study of boreal aerosol production and change (Tunved et al., 2006a, b, 2008). In marine regions, station observations have established links between DMS, aerosol, temperature and cloudiness (e.g., Ayers and Gras, 1991; Ayers et al., 1997; Boers et al., 1994) although the lack of supporting measurements of ocean biological and physical state highlights the difficulty of comprehensive measurements in all environments. Although the number of long term dust records is small, we have learned a great deal about climate impacts by combining observations with climate data and global models (e.g., Prospero and Lamb, 2002; Mahowald et al., 2002).

Several feedback mechanism and particularly processes behind them can be tested in laboratory experiments. For example, Joutsensaari et al. (2005) and Mentel et al. (2009) studied photochemical production of aerosols using living plants in environmental chambers. In the ocean, iron solubility of real aerosol in natural sea water has been studied in a flow reactor (Wu et al., 2007), and the physical and chemical properties of aerosol generated from bubble bursting in natural sea water has been measured (Keene et al., 2007). Mesocosm experiments that probe the response of natural marine (Vogt et al., 2008) and terrestrial (Pegoraro et al., 2005) systems are valuable controlled experiments. In a similar way the effect of changing climate conditions can and has been investigated for other aerosol systems.

At larger scales, satellite observations enable long term global changes to be observed. Satellite observations have been used, for example, to measure ocean chlorophyll (as a proxy for primary productivity) and its relation to $\mathrm{CCN}$, and to detect and quantify changes in wildfires. However, quantities such as chlorophyll and aerosol optical depth, while useful for some aspects of model evaluation, cannot provide the detailed information required to evaluate some key model processes.

\subsubsection{Development of models}

Quantification of global scale feedbacks associated with natural aerosols requires an Earth system model. Such models differ from climate models in the number and complexity of the physical, chemical and biological processes that are represented. They typically aim to couple the Earth's various components: physics and chemistry of the atmosphere, oceans, cryosphere, and the terrestrial and oceanic biosphere, and to quantify the interactions between these components and their impacts on each other.

The drivers of changes in aerosol are very numerous and present a substantial challenge for the development and evaluation of Earth system models. The direct climate drivers are: temperature, wind speed, precipitation (and associated convection and lightning), radiation, sea ice and snow coverage, $\mathrm{CO}_{2}$ concentrations, nutrients (reactive nitrogen, iron, etc.), and changes in oxidants and other trace species. Anthropogenically driven changes in land use, fire suppression, etc. are also important. The indirect drivers, which respond to the direct climate drivers, include: wind stress, ocean mixed layer depth and stratification, soil wetness, vegetation distribution, terrestrial vegetation and marine phytoplankton species composition, foliar biomass, primary productivity, and fire severity and frequency. All of these need to be simulated in Earth system models.

A common thread in all of the aerosol systems we have reviewed is the need for development of increasingly complex chains of models even for single feedbacks. The coupling of systems further complicates matters. Model evaluation and uncertainty analysis is therefore substantially more challenging than for physical climate systems alone. For example, modeling the effect of BVOC emissions on climate requires models of photosynthesis, autotrophic respiration and VOC synthesis at cell and leaf scales. Atmospheric models of VOC chemical degradation, particle nucleation together with condensation/evaporation and coagulation are required to understand SOA aerosol dynamics. The drivers of change in this system are related to the carbon cycle, soil nutrients and hydrology and the fate of the aerosol is related to changes in boundary layer dynamics, temperature, changes in oxidants and deposition processes on a global scale. In order to be able to simulate global climate and air quality, the most recent progress on this chain of processes must be compiled, integrated and implemented in numerical Earth system models via novel parameterizations. 
What are the requirements for atmospheric models of the aerosol and chemical processes specifically? Aerosol and number and mass concentrations are not necessarily linearly dependent on each other. Therefore both should be known to predict feedbacks. For example, dust, sea salt and biomass burning will enhance mass and surface area, which will decrease new particle formation and number concentrations. As a consequence of this coupling, changes in $\mathrm{CCN}$ may not scale linearly with emissions (Merikanto et al., 2009). The present generation of global aerosol microphysics models are a necessary and computationally feasible component of Earth system models. However, a major obstacle to the development of Earth system models is the requirement to simplify complex and numerically demanding gas phase chemical schemes, such as for DMS, halogens, BVOC degradation and SOA formation (Sects. 2.1.1 and 3.4). Studies should seek to find minimum schemes with maximum explanatory power if they are to be most useful in Earth system studies.

\section{Glossary}

AOD: aerosol optical depth

BC: black carbon

BVOC: biogenic volatile organic compounds

$\mathrm{CCN}$ : cloud condensation nucleus

CLAW: Charlson-Lovelock-Andreae-Warren hypothesis

DMS: dimethylsulphide

DMSP: dimethylsulphoniopropionate

ESM: Earth System Model

FT: free troposphere

GCM: general circulation model

MBL: marine boundary layer

MSA: methanesulphonic acid

OC: organic carbon

PAR: photosynthetically available radiation

PBAP: primary biological aerosol particles

$\mathrm{RF}$ : radiative forcing

SOA: secondary organic aerosol

SRD: solar radiation dose

VOC: volatile organic compounds
Acknowledgements. This work was supported by the EUCAARI project from Framework Programme 7 of the European Commission and the NERC QUEST programme. GWM received funding from the UK National Centre for Atmospheric Science (NCAS). The Met Office Hadley Centre is also supported by the Joint DECC and Defra Integrated Climate Programme - DECC/Defra (GA01101). We acknowledge S. Mayhew for his help to process the references.

Edited by: O. Hov

\section{References}

Adams, J. M., Constable, J. V. H., Guenther, A. B., and Zimmerman, P.: An estimate of natural volatile organic compound emissions from vegetation since the last glacial maximum, Chemosphere - Glob. Change Sci., 3, 73-91, 2001.

Adams, P. J. and Seinfeld, J. H.: Predicting global aerosol size distributions in general circulation models, J. Geophys. Res.Atmos., 107, 4370, doi:10.1029/2001JD001010, 2002.

Alfaro, S. C. and Gomes, L.: Modeling mineral aerosol production by wind erosion: Emission intensities and aerosol size distributions in source areas, J. Geophys. Res., 106, 18075-18084, 2001.

Allan, J. D., Alfarra, M. R., Bower, K. N., Coe, H., Jayne, J. T., Worsnop, D. R., Aalto, P. P., Kulmala, M., Hyötyläinen, T., Cavalli, F., and Laaksonen, A.: Size and composition measurements of background aerosol and new particle growth in a Finnish forest during QUEST 2 using an Aerodyne Aerosol Mass Spectrometer, Atmos. Chem. Phys., 6, 315-327, 2006, http://www.atmos-chem-phys.net/6/315/2006/.

Amiro, B. D., Cantin, A., Flannigan, M. D., and de Groot, W. J.: Future emissions from Canadian boreal forest fires, Can. J. Forest Res., 39, 383-395, doi:10.1139/X08-154, 2009.

Anderson, T. R., Spall, S. A., Yool, A., Cipollini, P., Challenor, P. G., and Fasham, M. J. R.: Global fields of sea surface dimethylsulfide predicted from chlorophyll, nutrients and light, J. Marine Syst., 30, 1-20, 2001.

Andreae, M. O., Rosenfeld, D., Artaxo, P., Costa, A. A., Frank, G. P., Longo, K. M., and Silva-Dias, M. A. F.: Smoking rain clouds over the Amazon, Science, 303, 1337-1342, 2004.

Andreae, M. O.: Aerosols before pollution, Science, 315(50-51), 5808, 2007.

Andreae, M. O. and Rosenfeld, D.: Aerosol-cloud-precipitation interactions. Part 1. The nature and sources of cloud-active aerosols, Earth Sci. Rev., 89, 13-41, 2008.

Aragao, L. E. O. C., Malhi, Y., Barbier, N., Lima, A., Shimabukuro, Y., Anderson, L., and Saatchi, S.: Interactions between rainfall, deforestation and fires during recent years in the Brazilian Amazonia, Phil. Trans. Roy. Soc. B, 363, 1779-1785, 2008.

Archer, S.: Crucial uncertainties in predicting biological control of DMS emission, Environ. Chem., 4, 404-405, 2007.

Arimoto, R.: Aeolian dust and climate: relationships to sources, tropospheric chemistry, transport and deposition, Earth Sci. Rev., 54, 29-42, 2001.

Ariya, P. A. and Amyot, M.: New directions: The role of bioaerosols in atmospheric chemistry and physics, Atmos. Environ., 38, 1231-1232, 2004.

Arneth, A., Niinemets, Ü., Pressley, S., Bäck, J., Hari, P., Karl, T., Noe, S., Prentice, I. C., Serça, D., Hickler, T., Wolf, A., 
and Smith, B.: Process-based estimates of terrestrial ecosystem isoprene emissions: incorporating the effects of a direct $\mathrm{CO}_{2}$ isoprene interaction, Atmos. Chem. Phys., 7, 31-53, 2007a, http://www.atmos-chem-phys.net/7/31/2007/.

Arneth, A., Miller, P. A., Scholze, M., Hickler, T., Schurgers, G., Smith, B., and Prentice, I. C.: $\mathrm{CO}_{2}$ inhibition of global terrestrial isoprene emissions: Potential implications for atmospheric chemistry, Geophys. Res. Lett., 34, L18813, doi:10.1029/2007GL030615, 2007b.

Arneth, A., Monson, R. K., Schurgers, G., Niinemets, Ü., and Palmer, P. I.: Why are estimates of global terrestrial isoprene emissions so similar (and why is this not so for monoterpenes)?, Atmos. Chem. Phys., 8, 4605-4620, 2008, http://www.atmos-chem-phys.net/8/4605/2008/.

Arnold, S. R., Spracklen, D. V., Williams, J., Yassaa, N., Sciare, J., Bonsang, B., Gros, V., Peeken, I., Lewis, A. C., Alvain, S., and Moulin, C.: Evaluation of the global oceanic isoprene source and its impacts on marine organic carbon aerosol, Atmos. Chem. Phys., 9, 1253-1262, 2009,

http://www.atmos-chem-phys.net/9/1253/2009/.

Arora, V. K. and Boer, G. J.: Fire as an interactive component of dynamic vegetation models, J. Geophys. Res., 110, G02008, doi:10.1029/2005JG000042, 2005.

Avise, J., Chen, J., Lamb, B., Wiedinmyer, C., Guenther, A., Salathé, E., and Mass, C.: Attribution of projected changes in summertime US ozone and $\mathrm{PM}_{2.5}$ concentrations to global changes, Atmos. Chem. Phys., 9, 1111-1124, 2009, http://www.atmos-chem-phys.net/9/1111/2009/.

Ayers, G. P. and Gras, J. L.: Seasonal relationship between cloud condensation nuclei and aerosol methanesulfonate in marine air, Nature, 353, 834-835, 1991.

Ayers, G. P. and Cainey, J. M.: The CLAW hypothesis: a review of the major developments, Environ. Chem., 4, 366-374, 2007.

Ayers, G. P., Cainey, J. M., Gillett, R. W., and Ivey, J. P: Atmospheric sulphur and cloud condensation nuclei in marine air in the southern Hemisphere, Phil. Trans. Roy. Soc. B, 352, 203211, 1997.

Bachelet, D., Neilson, R. P., Hickler, T., Drapek, R. J., Lenihan, J. M., Sykes, M. T., Smith, B., Sitch, S., and Thonicke, K.: Simulating past and future dynamics of natural ecosystems in the United States, Global Biogeochem. Cy., 17, 1045, doi:10.1029/2001GB001508, 2003.

Balkanski, Y., Schulz, M., Claquin, T., and Guibert, S.: Reevaluation of Mineral aerosol radiative forcings suggests a better agreement with satellite and AERONET data, Atmos. Chem. Phys., 7, 81-95, 2007, http://www.atmos-chem-phys.net/7/81/2007/.

Barnes, I., Hjorth, J., Mihalopoulos, N., et al.: Dimethyl sulfide and dimethyl sulfoxide and their oxidation in the atmosphere, Chem. Rev., 106, 940-975, 2006.

Bauer, H., Giebl, H., Hitzenberger, R., Kasper-Giebl, A., Reischl, G., Zibuschka, F., and Puxbaum, H.: Airborne bacteria as cloud condensation nuclei, J. Geophys. Res.-Atmos., 108, 4658, doi:10.1029/2003JD003545, 2003.

Bauer, S. E. and Koch, D.: Impact of heterogeneous sulfate formation at mineral dust surfaces on aerosol loads and radiative forcing in the Goddard Institute for Space Studies general circulation model, J. Geophys. Res., 110, D17202, doi:10.1029/2005JD005870, 2005.
Behrenfeld, M. J., O’Malley, R. T., Siegel, D. A., et al.: Climatedriven trends in contemporary ocean productivity, Nature, 444, 752-755, 2006.

Bergeron, Y. P. and Flannigan, M.: Predicting the effects of climate change on fire frequency in the southeastern Canada boreal forest, Water Air Soil Poll., 82, 437-444, 1995.

Bian, H. and Zender, C. S.: Mineral dust and global tropospheric chemistry: Relative roles of photolysis and heterogeneous uptake, J. Geophys. Res., 108, 4672, doi:10.1029/2002JD003143, 2003.

Bigg, E. K. and Leck, C.: The composition of fragments of bubbles bursting at the ocean surface, J. Geophys. Res., 113, D11209, doi:10.1029/2007JD009078, 2008.

Blain, S., Queguiner, B., Armand, L., et al.: Effect of natural iron fertilization on carbon sequestration in the southern ocean, Nature, 446, 1070-1071, 2007.

Blanchard, D. C.: Sea-to-air transport of surface active material, Science, 146, 396-397, 1964.

Boers, R., Ayers, G. P., and Gras, J. L.: Coherence between seasonal-variation in satellite-derived cloud optical depth and boundary-layer $\mathrm{CCN}$ concentrations at a midlatitude southernhemisphere station, Tellus B, 46, 123-131, 1994.

Bonn, B., Kulmala, M., Riipinen, I., et al.: How biogenic terpenes govern the correlation between sulfuric acid concentrations and new particle formation, J. Geophys. Res., 113, D12209, doi:10.1029/2007JD009327, 2008.

Bonsang, B., Polle, C., Lambert, G., et al.: Evidence for marine production of isoprene, Geophys. Res. Lett., 19, 1129-1132, 1992.

Bopp, L., Kohfeld, K. E., Le Quere, C., et al.: Dust impact on marine biota and atmospheric $\mathrm{CO}_{2}$ during glacial periods, Paleoceanography, 18, 1046, doi:10.1029/2002PA000810, $2003 \mathrm{a}$.

Bopp, L., Aumont, O., Belviso, S., and Monfray, P.: Potential impact of climate change on marine dimethyl sulfide emissions, Tellus B, 55, 11-22, 2003b.

Bopp, L., Boucher, O., Aumont, O., Belviso, S., Dufresne, J. L., Monfray, P., and Pham, M.: Will marine dimethylsulfide emissions amplify or alleviate global warming?, Can. J. Marine Fish., 61, 826-835, 2004.

Boucher, O. and Pham, M.: History of sulfate aerosol radiative forcings, Geophys. Res. Lett., 29, 1308, doi:10.1029/2001GL014048, 2002.

Boucher, O., Moulin, C., Belviso, S., Aumont, O., Bopp, L., Cosme, E., von Kuhlmann, R., Lawrence, M. G., Pham, M., Reddy, M. S., Sciare, J., and Venkataraman, C.: DMS atmospheric concentrations and sulphate aerosol indirect radiative forcing: a sensitivity study to the DMS source representation and oxidation, Atmos. Chem. Phys., 3, 49-65, 2003, http://www.atmos-chem-phys.net/3/49/2003/.

Boy, J. and Wilcke, W.: Tropical Andean forest derives calcium and magnesium from Saharan dust, Global Biogeochem. Cy., 22, GB1027, doi:10.1029/2007GB002960, 2008.

Boyd, P. W.: Environmental factors controlling phytoplankton processes in the southern ocean, J. Phycol., 38, 844-861, 2002.

Boyd, P. W. and Doney, S. C.: Modeling regional responses by marine pelagic ecosystems to global climate change, Geophys. Res. Lett., 29, 1806, doi:10.1029/2001GL014130, 2002.

Boyd, P. W., Jickells, T., Law, C. S., et al.: Mesoscale iron enrichment experiments 1993-2005: Synthesis and future directions, Science, 315, 612-617, 2007. 
Brown, T., Hall, B., and Westerling, A.: The impact of twenty-first century climate change on wildland fire danger in the western United States: An applications perspective, Climatic Change, 62, 365-388, 2004

Bryant, R. G., Bigg, G. R., Mahowald, N. M., Eckardt, F. D., and Ross, S. G.: Dust emission response to climate in southern Africa, J. Geophys. Res., 112, D09207, doi:10.1029/2005JD007025, 2007.

Bullard, J., Baddock, M., McTainsh, G., and Leys, J.: Sub-basin scale dust source geomorphology detected using MODIS, Geophys. Res. Lett., 35, L15404, doi:10.1029/2008GL039928, 2008.

Burke, E. J., Brown, S. J., and Christidis, N.: Modeling the recent evolution of global drought and projections for the twenty-first century with the Hadley Centre Climate Model, J. Hydrometeor., 7, 1113-1125, 2006.

Butchart, N. and Scaife, A. A.: Removal of chloroflurocarbons by increased mass exchange between the stratosphere and troposphere in a changing climate, Nature, 410, 799-802, 2001.

Butchart, N., Scaife, A. A., Bourqui, M., de Grandpré, J., Hare, S. H. E., Kettleborough, J., Langematz, U., Manzini, E., Sassi, F., Shibata, K., Shindell, D., and Sigmond, M.: Simulations of anthropogenic change in the strength of the Brewer-Dobson circulation, Clim. Dynam., 27, doi:10.1007/s00382-006-0162-4, 2006.

Caffrey, P. F., Hoppel, W. A., and Shi, J. J.: A one-dimensional sectional aerosol model integrated with mesoscale meteorological data to study marine boundary layer aerosol dynamics, J. Geophys. Res., 111, D24201, doi:10.1029/2006JD007237, 2006.

Caldeira, K. and Wickett, M. E.: Anthropogenic carbon and ocean $\mathrm{pH}$, Nature, 425, 365-365, 2003.

Caldwell, M. M., Bornman, J. F., Ballaré, C. L., Flint, S. D., and Kulandaivelu, G.: Terrestrial ecosystems, increased solar ultraviolet radiation, and interactions with other climate change factors, Photoch. Photobio. Sci., 6, 252-266, 2007.

Cape, J. N.: Interactions of forests with secondary air pollutants: Some challenges for future research, Environ. Pollut., 155, 391397, 2008

Cardoso, M. F., Hurtt, G. C., Moore III, B., Nobre, C. A., and Prins, E. M.: Projecting future fire activity in Amazonia, Glob. Change Biol., 9, 656-669, 2003.

Carpenter, L. J., Liss, P. S., and Penkett, S. A.: Marine organohalogens in the atmosphere over the Atlantic and southern oceans, J. Geophys. Res., 108, 4256, doi:10.1029/2002JD002769, 2003.

Cassar, N., Bender, M. L., Barnett, B. A., et al.: The southern ocean biological response to aeolian iron deposition, Science, 317, 1067-1070, 2007.

Cavalli, F., Facchini, M. C., Decesari, S., et al.: Advances in characterization of size-resolved organic matter in marine aerosol over the North Atlantic, J. Geophys. Res., 109, D24215, doi:10.1029/2004JD005137, 2004.

Ceburnis, D., O’Dowd, C. D., Jennings, G. S., Facchini, M. C., Emblico, L., Decesari, S., Fuzzi, S., and Sakalys, J.: Marine aerosol chemistry gradients: Elucidating primary and secondary processes and fluxes, Geophys. Res. Lett., 35, L07804, doi:10.1029/2008GL033462, 2008.

Charlson, R. J., Lovelock, J. E, Andreae, M. O., and Warren, S. G.: Oceanic phytoplankton, atmospheric sulfur, cloud albedo and climate, Nature, 326, 655-661, 1987.

Chen, Q., Farmer, D. K., Schneider, J., Zorn, S. R., et al.: Mass spectral characterization of submicron biogenic organic particles in the Amazon Basin, Geophys. Res. Lett., 36, L20806, doi:10.1029/2009GL039880, 2009.

Chin, M. A. and Jacob, D. J.: Anthropogenic and natural contributions to tropospheric sulfate: A global model analysis, J. Geophys. Res., 101, 18691-18699, 1996.

Christner, B. C., Cai, R., Morris, C. E., et al.: Geographic, seasonal, and precipitation chemistry influence on the abundance and activity of biological ice nucleators in rain and snow, P. Natl. Acad. Sci. USA, 105, 18854-18859, 2008.

Claquin, T., Schulz, M., and Balkanski, Y. J.: Modeling the mineralogy of atmospheric dust sources, J. Geophys. Res., 104, 22243 22256, 1999.

Clarke, A. D., Owens, S. R., and Zhou, J.: An ultrafine sea-salt flux from breaking waves: Implications for cloud condensation nuclei in the remote marine atmosphere, J. Geophys. Res., 111, D06202, doi:10.1029/2005JD006565, 2006.

Collins, W. J., Derwent, R. G., Garnier, B., Johnson, C. E., Sanderson, M. G., and Stevenson, D. S.: Effect of stratospheretroposphere exchange on future tropospheric ozone trend, J. Geophys. Res., 108, 8528, doi:10.1029/2002JD002617, 2003.

Cox, P. M., Betts, R. A., Jones, C. D., Spall, S. A., and Totterdell, I. J.: Acceleration of global warming due to carbon-cycle feedbacks in a coupled climate model, Nature, 408, 184-187, 2000.

Cox, P. M., Betts, R. A., Collins, M., Harris, P. P., Huntingford, C., and Jones, C. D.: Amazon forest dieback under climate-carbon cycle projections for the 21st century, Theor. Appl. Climatol., 78, 137-156, 2004.

Cox, P. M., Harris, P. P., Huntingford, C., et al: Increasing risk of Amazonian drought due to decreasing aerosol pollution, Nature, 453, 212-215, 2008.

Cropp, R. A., Gabric, A. J., McTainsh, G. H., Braddock, R. D., and Tindale, N.: Coupling between ocean biota and atmospheric aerosols: Dust, dimethylsulphide, or artifact?, Global Biogeochem. Cy., 19, GB4002, doi:10.1029/2004GB002436, 2005.

Curran, M. A. J., Van Ommen, T. D., Morgan, V. I., et al.: Ice core evidence for Antarctic sea ice decline since the 1950s, Science, 302, 1203-1206, 2003.

de Gouw, J. A., Middlebrook, A. M., Warneke, C., et al.: Budget of organic carbon in a polluted atmosphere: Results from the New England Air Quality Study in 2002, J. Geophys. Res., 110, D16305, doi:10.1029/2004JD005623, 2005.

DeMott, P. J., Sassen, K., Poellot, M. R., et al.:African dust aerosols as atmospheric ice nuclei, Geophys. Res. Lett., 30, 1732, doi:10.1029/2003GL017410, 2003.

Dentener, F., Carmichael, G., Zhang, Y., Lelieveld, J., and Crutzen, P.: Role of mineral aerosol as a reactive surface in the global troposphere, J. Geophys. Res., 101, 22869-22889, 1996.

Dentener, F., Kinne, S., Bond, T., Boucher, O., Cofala, J., Generoso, S., Ginoux, P., Gong, S., Hoelzemann, J. J., Ito, A., Marelli, L., Penner, J. E., Putaud, J.-P., Textor, C., Schulz, M., van der Werf, G. R., and Wilson, J.: Emissions of primary aerosol and precursor gases in the years 2000 and 1750 prescribed data-sets for AeroCom, Atmos. Chem. Phys., 6, 4321-4344, 2006, http://www.atmos-chem-phys.net/6/4321/2006/.

Driscoll, C. T., Lawrence, G. B., Bulger, A. J., et al.: Acidic deposition in the northeastern United States: sources and in puts, ecosystem effects, and management strategies, BioScience, 
51(3), 180-198, 2001.

Duhl, T. R., Helmig, D., and Guenther, A.: Sesquiterpene emissions from vegetation: a review, Biogeosciences, 5, 761-777, 2008, http://www.biogeosciences.net/5/761/2008/.

Elbert, W., Taylor, P. E., Andreae, M. O., and Pöschl, U.: Contribution of fungi to primary biogenic aerosols in the atmosphere: wet and dry discharged spores, carbohydrates, and inorganic ions, Atmos. Chem. Phys., 7, 4569-4588, 2007, http://www.atmos-chem-phys.net/7/4569/2007/.

Erickson, D. J., Hernandez, J. L., Ginoux, P., Gregg, W. W., McClain, C., and Christian, J.: Atmospheric iron delivery and surface biological activity in the southern ocean and patagonian region, Geophys. Res. Lett., 30, 1609, doi:10.1029/2003GL017241, 2003.

Fabian, P., Kohlpaintner, M., and Rollenbeck, R.: Biomass burning in the Amazon - fertilizer for the mountaineous rain forest in Ecuador, Environ. Sci. Pollut. R., 12(5), 290-296, 2005.

Fan, S.-M., Horowitz, L. W., Levy II, H., and Moxim, W. J.: Impact of air pollution on wet deposition of mineral dust aerosols, Geophys. Res. Lett., 31, L02104, doi:10.1029/2003GL018501, 2004.

Fan, S.-M., Moxim, W. J., and Levy II, H.: Aeolian input of bioavailable iron to the ocean, Geophys. Res. Lett., 33, L07602, doi:10.1029/2005GL024852, 2006.

Feichter, J., Roeckner, E., Lohmann, U., and Liepert, B.: Nonlinear aspects of the climate response to greenhouse gas and aerosol forcing, J. Climate, 17, 2384-2398, 2004.

Feingold, G., Cotton, W. R., Kreidenweis, S. M., et al.: The impact of giant cloud condensation nuclei on drizzle formation in stratocumulus: Implications for cloud radiative properties, J. Atmos. Sci., 56(24), 4100-4117, 1999.

Finlayson-Pitts, B. J. and Pitts, J. N.: Chemistry of the Upper and Lower Atmosphere, Academic Press, San Diego, California, 2000.

Flanner, M. G., Zender, C. S., Randerson, J. T., and Rasch, P. J.: Present-day climate forcing and response from black carbon in snow, J. Geophys. Res., 112, D11202, doi:10.1029/2006JD008003, 2007.

Flannigan, M. D., Logan, K. A., Amiro, B. D., Skinner, W. R., and Stocks, B. J.: Future area burned in Canada, Climatic Change, 72, 1-16, doi:10.1007/s10584-005-5935-y, 2005.

Flannigan, M. and Van Wagner, C.: Climate change and wildfire in Canada, Can. J. Forest Res., 21, 66-72, 1991.

Flannigan, M., Stocks, B., and Wotton, B.: Climate change and forest fires, Sci. Total Environ., 262, 221-229, 2000.

Flannigan, M., Campbell, I., Wotton, M., Carcaillet, C., Richard, P., and Bergeron, Y.: Future fire in Canada's boreal forest: paleoecology results and general circulation model - regional climate model simulations, Can. J. Forest Res., 31, 854-864, 2001.

Flannigan, M. D., Krawchuk, M. A., de Groot, W. J. et al.: Implications of changing climate for global wildland fire, Int. J. Wildland Fire, 18, 483-507, 2009.

Forster, P., Ramaswamy, V., Artaxo, P., et al.: Changes in Atmospheric Constituents and in Radiative Forcing, in: Climate Change 2007: The Physical Science Basis, Contribution of Working Group I to the Fourth Assessment Report of the Intergovernmental Panel on Climate Change, edited by: Solomon, S., Qin, D., Manning, M., Chen, Z., Marquis, M., Averyt, K. B., Tignor, M., and Miller, H. L., Cambridge University Press, Cam- bridge, UK and New York, NY, USA, 129-234, 2007.

Fuzzi, S., Andreae, M. O., Huebert, B. J., Kulmala, M., Bond, T. C., Boy, M., Doherty, S. J., Guenther, A., Kanakidou, M., Kawamura, K., Kerminen, V.-M., Lohmann, U., Russell, L. M., and Pöschl, U.: Critical assessment of the current state of scientific knowledge, terminology, and research needs concerning the role of organic aerosols in the atmosphere, climate, and global change, Atmos. Chem. Phys., 6, 2017-2038, 2006, http://www.atmos-chem-phys.net/6/2017/2006/.

Gabric, A., Murray, N., Stone, L., and Kohl, M.: Modeling the production of Dimethylsulfide during a phytoplankton bloom, J. Geophys. Res., 98, 22805-22816, 1993.

Gabric, A. J., Whetton, P. H., Boers, R., et al.: The impact of simulated climate change on the air-sea flux of dimethylsulphide in the subantarctic southern ocean, Tellus B, 50, 388-399, 1998.

Gabric, A. J., Whetton, P. H., Cropp, R., et al.: Dimethylsulphide production in the subantarctic southern ocean under enhanced greenhouse conditions, Tellus B, 53, 273-287, 2001.

Gabric, A. J., Cropp, R., Hirst, T., and Marchant, H.: The sensitivity of dimethyl sulfide production to simulated climate change in the eastern antarctic southern ocean, Tellus B, 55, 966-981, 2003.

Gabric, A. J., Simó, R., Cropp, R. A., Hirst, A. C., and Dachs, J.: Modeling estimates of the global emission of dimethylsulfide under enhanced greenhouse conditions, Global Biogeochem. Cy., 18, GB2014, doi:10.1029/2003GB002183, 2004.

Gabric, A. J., Qu, B., Matrai, P., et al.: The simulated response of dimethylsulfide production in the arctic ocean to global warming, Tellus B, 57, 391-403, 2005.

Garcia, R. R. and Randel, W. J.: Acceleration of the Brewer-Dobson circulation due to increases in greenhouse gases, J. Atmos. Sci., 65, 2731-2739, 2008.

Gauci, V., Dise, N. B., Howell, G., and Jenkins, M. E.: Suppression of rice methane emission by sulfate deposition in simulated acid rain, J. Geophys. Res., 113, G00A07, doi:10.1029/2007JG000501, 2008.

Geever, M., O’Dowd, C. D., van Ekeren, S., Flanagan, R., Nilsson, D. E., de Leeuw, G., and Rannik, Ü.: Submicron sea spray fluxes, Geophys. Res. Lett., 32, L15810, doi:10.1029/2005GL023081, 2005.

Generoso, S., Bréon, F.-M., Balkanski, Y., Boucher, O., and Schulz, M.: Improving the seasonal cycle and interannual variations of biomass burning aerosol sources, Atmos. Chem. Phys., 3, 12111222, 2003, http://www.atmos-chem-phys.net/3/1211/2003/.

Gillett, N. P., Weaver, A. J., Zwiers, F. W., and Flannigan, M. D.: Detecting the effect of climate change on Canadian forest fires, Geophys. Res. Lett., 31, L18211, doi:10.1029/2004GL020876, 2004.

Goldstein, A. H. and Galbally, I. E.: Known and unexplored organic carbon constituents in the Earth's atmosphere, Environ. Sci. Technol., 41, 1514-1521, 2007.

Gondwe, M., Krol, M., Gieskes, W., Klaassen, W., and de Baar, H.: The contribution of ocean-leaving DMS to the global atmospheric burdens of DMS, MSA, $\mathrm{SO}_{2}$, and $\mathrm{NSS} \mathrm{SO}_{4}^{=}$, Global Biogeochem. Cy., 17, 1056, doi:10.1029/2002GB001937, 2003.

Gregg, W. W. and Conkright, M. E.: Decadal changes in global ocean chlorophyll, Geophys. Res. Lett., 29, 1730, doi:10.1029/2002GL014689, 2002.

Griffin, D. W., Westphal, D. L., and Gray, M. A.: Airborne microor- 
ganisms in the African desert dust corridor over the mid-Atlantic ridge, Ocean Drilling Program, Leg 209, Aerobiologia, 22, 211226, 2006.

Grini, A. and Zender, C. S.: Roles of saltation, sandblasting, and wind speed variability on mineral dust aerosol size distribution during the Puerto Rican Dust Experiment (PRIDE), J. Geophys. Res., 109, D07202, doi:10.1029/2003JD004233, 2004.

Gu, L., Baldocchi, D., Verma, S. B., Black, T. A., Vesala, T., Falge, E. M., and Dowty, P. R.: Advantages of diffuse radiation for terrestrial ecosystem productivity, J. Geophys. Res., 107(D6), 4050, doi:10.1029/2001JD001242, 2002.

Gu, L., Baldocchi, D. D., Wofsy, S. C., Munger, J. W., Michalsky, J. J., Urbanski, S. P., and Boden, T. A.: Response of a deciduous forest to the Mount Pinatubo eruption: enhanced photosynthesis, Science, 299, 2035-2038, 2003.

Guenther, A., Hewitt, C. N., Erickson, D., et al.: A global model of natural volatile organic compound emissions, J. Geophys. Res., 100, 8873-8892, 1995.

Guenther, A., Karl, T., Harley, P., Wiedinmyer, C., Palmer, P. I., and Geron, C.: Estimates of global terrestrial isoprene emissions using MEGAN (Model of Emissions of Gases and Aerosols from Nature), Atmos. Chem. Phys., 6, 3181-3210, 2006, http://www.atmos-chem-phys.net/6/3181/2006/.

Gunson, J. R., Spall, S. A., Anderson, T. R., et al.: Climate sensitivity to ocean dimethylsulphide emissions, Geophys. Res. Lett., 33, L07701, doi:10.1029/2005GL024982, 2006.

Häder, D.-P., Kumar, H. D., Smith, R. C., and Worrest, R. C.: Effects of solar UV radiation on aquatic ecosystems and interactions with climate change, Photochem. Photobio. S., 6, 267-285, 2007.

Hallquist, M., Wenger, J. C., Baltensperger, U., Rudich, Y., Simpson, D., Claeys, M., Dommen, J., Donahue, N. M., George, C., Goldstein, A. H., Hamilton, J. F., Herrmann, H., Hoffmann, T., Iinuma, Y., Jang, M., Jenkin, M. E., Jimenez, J. L., Kiendler-Scharr, A., Maenhaut, W., McFiggans, G., Mentel, Th. F., Monod, A., Prévôt, A. S. H., Seinfeld, J. H., Surratt, J. D., Szmigielski, R., and Wildt, J.: The formation, properties and impact of secondary organic aerosol: current and emerging issues, Atmos. Chem. Phys., 9, 5155-5235, 2009,

http://www.atmos-chem-phys.net/9/5155/2009/.

Hari, P. and Kulmala, M.: Station for Measuring EcosystemsAtmosphere Relations (SMEAR II), Boreal Env. Res., 10, 315322, 2005.

Harrison, S. P., Kohfeld, K. E., Roelandt, C., and Claquin, T.: The role of dust in climate changes today, at the last glacial maximum and in the future, Earth Sci. Rev., 54, 43-80, 2001.

Haywood, J. and Boucher, O.: Estimates of the direct and indirect radiative forcing due to tropospheric aerosols: A review, Rev. Geophys., 38, 513-543, 2000.

Heald, C. L., Jacob, D. J., Park, R. J., Russell, L. M., et al.: A large organic aerosol source in the free troposphere missing from current models, Geophys. Res. Lett., 32, L18809, doi:10.1029/2005GL023831, 2005.

Heald, C. L., Jacob, D. J., Turquety, S., et al.: Concentrations and sources of organic carbon aerosols in the free troposphere over North America, J. Geophys. Res., 111, D23S47, doi:10.1029/2006JD007705, 2006a.

Heald, C. L., Jacob, D. J., Park, R. J., et al.: Transpacific transport of Asian anthropogenic aerosols and its impact on surface air quality in the United States, J. Geophys. Res., 111, D14310, doi:10.1029/2005JD006847, 2006b.

Heald, C. L., Henze, D. K., Horowitz, L. W., et al.: Predicted change in global secondary organic aerosol concentrations in response to future climate, emissions, and land use change, J. Geophys. Res., 113, D05211, doi:10.1029/2007JD009092, 2008.

Heald, C. L., Wilkinson, M. J., Monson, R. K., et al.: Response of isoprene emission to ambient $\mathrm{CO}_{2}$ changes and implications for global budgets, Glob. Change Biol., 15, 1127-1140, doi:10.1111/j.1365-2486.2008.01802.x, 2009.

Heald, C. L. and Spracklen, D. V.: Atmospheric budget of primary biological aerosol particles from fungal sources, Geophys. Res. Lett., 36, L09806, doi:10.1029/2009GL037493, 2009.

Highwood, E. J., Haywood, J. M., Silverstone, M. D., Newman, S. M., and Taylor, J. P.: Radiative properties and direct radiative effect of Saharan dust measured by the C-130 aircraft during the Saharan Dust Experiment (SHADE). 2: terrestrial spectrum, J. Geophys. Res., 108, 8578, doi:10.1029/2002JD002552, 2003.

Hoelzemann, J., Schultz, M., Brasseur, G., Granier, C., and Simon, M.: Global Wildland Fire Emission Model (GWEM): Evaluating the use of global area burnt satellite data, J. Geophys. Res., 109, D14S04, doi:10.1029/2003JD003666, 2004.

Hoose, C., Lohmann, U., Erdin, R., and Tegen, I.: The global influence of dust mineralogical composition on heterogeneous ice nucleation in mixed-phase clouds, Env. Res. Lett., 3, 025003, doi:10.1088/1748-9326/3/2/025003, 2008.

Jaenicke, R.: Abundance of cellular material and proteins in the atmosphere, Science, 308, 73-73, doi:10.1126/science.1106335, 2005.

Jaffe, D., Hafner, W., Chand, D., Westerling, A., and Spracklen, D.: Interannual variations in PM2.5 due to Wildfires in the Western United States, Environ. Sci. Technol., 42(8), 2812-2818, doi:10.1021/es702755v, 2008.

Jiang X., Wiedinmyer, C., Chen, F., Yang, Z.-L., and Lo, J. C.F.: Predicted impacts of climate and land use change on surface ozone in the Houston, Texas, area, J. Geophys. Res., 113, D20312, doi:10.1029/2008JD009820, 2008.

Jickells, T. D., An, Z. S., Andersen, K. K., Baker, A. R., Bergametti, G., Brooks, N., Cao, J. J., Boyd, P. W., Duce, R. A., Hunter, K. A., Kawahata, H., Kubilay, N., laRoche, J., Liss, P. S., Mahowald, N., Prospero, J. M., Ridgwell, A. J., Tegen, I., and Torres, R.: Global iron connections between desert dust, ocean biogeochemistry, and climate, Science, 308(5718), 67-71, doi:10.1126/science.1105959, 2005.

Johnson, D., Utembe, S. R., Jenkin, M. E., Derwent, R. G., Hayman, G. D., Alfarra, M. R., Coe, H., and McFiggans, G.: Simulating regional scale secondary organic aerosol formation during the TORCH 2003 campaign in the southern UK, Atmos. Chem. Phys., 6, 403-418, 2006, http://www.atmos-chem-phys.net/6/403/2006/.

Jones, A. M. and Harrison, R. M.: The effects of meteorological factors on atmospheric bioaerosol concentrations - a review, Sci. Total Environ., 326, 151-180, 2004.

Jones, A., Roberts, D. L., Woodage, M. J., and Johnson, C. E.: Indirect sulphate aerosolforcing in a climate model with an interactive sulphur cycle, J. Geophys. Res., 106, 20293-20310, 2001.

Jones, A., Haywood, J. M., and Boucher, O.: Aerosol forcing, climate response and climate sensitivity in the Hadley Centre climate model, J. Geophys. Res., 112, D20211, 
doi:10.1029/2007JD008688, 2007.

Joutsensaari, J., Loivamäki, M., Vuorinen, T., Miettinen, P., Nerg, A.-M., Holopainen, J. K., and Laaksonen, A.: Nanoparticle formation by ozonolysis of inducible plant volatiles, Atmos. Chem. Phys., 5, 1489-1495, 2005,

http://www.atmos-chem-phys.net/5/1489/2005/.

Jung, E. and Shao, Y.: An intercomparison of four wet deposition schemes used in dust transport modeling, Global Planet. Change, 52, 248-260, 2006.

Kanakidou, M., Seinfeld, J. H., Pandis, S. N., Barnes, I., Dentener, F. J., Facchini, M. C., Van Dingenen, R., Ervens, B., Nenes, A., Nielsen, C. J., Swietlicki, E., Putaud, J. P., Balkanski, Y., Fuzzi, S., Horth, J., Moortgat, G. K., Winterhalter, R., Myhre, C. E. L., Tsigaridis, K., Vignati, E., Stephanou, E. G., and Wilson, J.: Organic aerosol and global climate modelling: a review, Atmos. Chem. Phys., 5, 1053-1123, 2005 , http://www.atmos-chem-phys.net/5/1053/2005/.

Kaplan, J. O., Folberth, G., and Hauglustaine, D. A.: Role of methane and biogenic volatile organic compound sources in late glacial and Holocene fluctuations of atmospheric methane concentrations, Global Biogeochem. Cy., 20, GB2016, doi:10.1029/2005GB002590, 2006.

Kaufman, Y. J., Koren, I., Remer, L. A., Tanré, D., Ginoux, P., and Fan, S.: Dust transport and deposition observed from the TerraMODIS spacecraft over the Atlantic Ocean, J. Geophys. Res., 110, D10S12, doi:10.1029/2003JD004436, 2005.

Keene, W. C., Maring, H., Maben, J. R., Kieber, D. J., Pszenny, A. A. P., Dahl, E. E., Izaguirre, M. A., Davis, A. J., Long, M. S., Zhou, X. L., Smoydzin, L., and Sander, R.: Chemical and physical characteristics of nascent aerosols produced by bursting bubbles at a model air-sea interface, J. Geophys. Res., 112, D21202, doi:10.1029/2007JD008464, 2007.

Kerminen, V., Lihavainen, H., Komppula, M., Viisanen, Y., and Kulmala, M.: Direct observational evidence linking atmospheric aerosol formation and cloud droplet activation, Geophys. Res. Lett., 32, L14803, doi:10.1029/2005GL023130, 2005.

Kloster, S., Feichter, J., Maier-Reimer, E., Six, K. D., Stier, P., and Wetzel, P.: DMS cycle in the marine ocean-atmosphere system a global model study, Biogeosciences, 3, 29-51, 2006, http://www.biogeosciences.net/3/29/2006/.

Kloster, S., Six, K. D., Feichter, J., Maier-Reimer, E., Roeckner, E., Wetzel, P., Stier, P., and Esch, M.: Response of dimethylsulfide (DMS) in the ocean and atmosphere to global warming, J. Geophys. Res., 112, G03005, doi:10.1029/2006JG000224, 2007.

Koch, D., Park, J., and Del Genio, A.: Clouds and sulfate are anticorrelated: A new diagnostic for global sulfur models, J. Geophys. Res., 108, 4781, doi:10.1029/2003JD003621, 2003.

Koga, T. and Tanaka, H.: Modeling the methansulphonate to nonsea-salt sulfate molar ratio and dimethylsulfide oxidation in the atmosphere, J. Geophys. Res., 104, 13735-13747, 1999.

Kohfeld, K. E. and Harrison, S. P.: The geologic record of dust, Earth Sci. Rev., 54, 81-114, 2001.

Kohfeld, K. E., Le Quéré, C., Harrison, S. P., and Anderson, R. F.: Role of marine biology in glacial-interglacial $\mathrm{CO}_{2}$ cycles, Science, 308, 74-78, 2005.

Korhonen, H., Carslaw, K. S., Spracklen, D. V., Mann, G. W., and Woodhouse, M. T.: Influence of oceanic dimethyl sulfide emissions on cloud condensation nuclei concentrations and seasonality over the remote southern hemisphere oceans:
A global model study, J. Geophys. Res., 113, D15204, doi:10.1029/2007JD009718, 2008.

Korhonen, H., Carslaw, K. S., Forster, P. M., et al.: Aerosol climate feedback due to decadal increases in southern hemisphere wind speeds, Geophys. Res. Lett., 37, L02805, doi:10.1029/2009GL041320, 2010.

Krinner, G., Boucher, O., and Balkanski, Y.: Ice-free glacial northern Asia due to dust deposition on snow, Clim. Dynam., 27, 613625, 2006.

Kroll, J. H., Ng, N. L., Murphy, S. M., Flagan, R. C., and Seinfeld, J. H.: Secondary organic aerosol formation from isoprene photooxidation under high- $\mathrm{NO}_{\mathrm{x}}$ conditions, Geophys. Res. Lett., 32, L18808, doi:10.1029/2005GL023637, 2005.

Kulmala, M., Laaksonen, A., and Pirjola, L.: Parameterizations for sulfuric acid/water nucleation rates, J. Geophys. Res., 103, 83018307, 1998.

Kulmala, M., Suni, T., Lehtinen, K. E. J., Dal Maso, M., Boy, M., Reissell, A., Rannik, Ü., Aalto, P., Keronen, P., Hakola, H., Bäck, J., Hoffmann, T., Vesala, T., and Hari, P.: A new feedback mechanism linking forests, aerosols, and climate, Atmos. Chem. Phys., 4, 557-562, 2004a, http://www.atmos-chem-phys.net/4/557/2004/.

Kulmala, M., Vehkamäki, H., Petäjä, T., Dal Maso, M., Lauri, A., Kerminen, V.-M., Birmili, W., and McMurry, P. H.: Formation and growth rates of ultrafine atmospheric particles: A review of observations, J. Aerosol Sci., 35, 143-176, 2004 b.

Kulmala, M., Kerminen, V. M., Laaksonen, A., et al.: Overview of the BACCI (Biosphere-Aerosol-Cloud-Climate Interactions) studies, Tellus B, 60, 300-317, 2008.

Kulmala, M., Asmi, A., Lappalainen, H. K., Carslaw, K. S., Pöschl, U., Baltensperger, U., Hov, Ø., Brenquier, J.-L., Pandis, S. N., Facchini, M. C., Hansson, H.-C., Wiedensohler, A., and O'Dowd, C. D.: Introduction: European Integrated Project on Aerosol Cloud Climate and Air Quality interactions (EUCAARI) - integrating aerosol research from nano to global scales, Atmos. Chem. Phys., 9, 2825-2841, 2009, http://www.atmos-chem-phys.net/9/2825/2009/.

Kurtén, T., Kulmala, M., Dal Maso, M., Suni, T., Reissell, A., Vehkamäki, H., Hari, P., Laaksonen, A., Viisanen, Y., and Vesala, T.: Estimation of different forest-related contributions to the radiative balance using observations in southern Finland, Boreal Env. Res., 8, 275-285, 2003

Laaksonen, A., Kulmala, M., O’Dowd, C. D., Joutsensaari, J., Vaattovaara, P., Mikkonen, S., Lehtinen, K. E. J., Sogacheva, L., Dal Maso, M., Aalto, P., Petäjä, T., Sogachev, A., Yoon, Y. J., Lihavainen, H., Nilsson, D., Facchini, M. C., Cavalli, F., Fuzzi, S., Hoffmann, T., Arnold, F., Hanke, M., Sellegri, K., Umann, B., Junkermann, W., Coe, H., Allan, J. D., Alfarra, M. R., Worsnop, D. R., Riekkola, M.-L., Hyötyläinen, T., and Viisanen, Y.: The role of VOC oxidation products in continental new particle formation, Atmos. Chem. Phys., 8, 2657-2665, 2008, http://www.atmos-chem-phys.net/8/2657/2008/.

Langmann, B., Scannell, C., and O'Dowd, C.: New Directions: Organic matter contribution to marine aerosols and cloud condensation nuclei, Atmos. Environ., 42, 7821-7822, 2008.

Larsen, S. H.: Solar variability, dimethyl sulphide, clouds, and climate, Global Biogeochem. Cy., 19, GB1014, doi:10.1029/2004GB002333, 2005.

Larsen, S. H.: Comment on "Analysis of a potential" solar radiation 
dose-dimethylsulfide-cloud condensation nuclei "link from globally mapped seasonal correlations" by S. M. Vallina et al., Global Biogeochem. Cy., 22, GB3005, doi:10.1029/2007GB003013, 2008.

Lathière, J., Hauglustaine, D. A., De Noblet-Ducoudré, N., Krinner, G., and Folberth, G. A.: Past and future changes in biogenic volatile organic compound emissions simulated with a global dynamic vegetation model, Geophys. Res. Lett., 32, L20818, doi:10.1029/2005GL024164, 2005.

Lathière, J., Hauglustaine, D. A., Friend, A. D., De NobletDucoudré, N., Viovy, N., and Folberth, G. A.: Impact of climate variability and land use changes on global biogenic volatile organic compound emissions, Atmos. Chem. Phys., 6, 2129-2146, 2006,

http://www.atmos-chem-phys.net/6/2129/2006/.

Laurance, W. F. and Williamson, G. B.: Positive feedbacks among forest fragmentation, drought, and climate change in the Amazon, Conserv. Biol., 15, 1529-1535, doi:10.1046/j.15231739.2001.01093.x, 2001.

Lawrence, M. G.: An empirical-analysis of the strength of the phytoplankton-dimethylsulfide-cloud-climate feedback cycle, J. Geophys. Res., 98, 20663-20673, 1993.

Le Quéré, C. L., Harrison, S. P., Prentice, I. C., et al.: Ecosystem dynamics based on plankton functional types for global ocean biogeochemistry models, Global Change Biol., 11, 2016-2040, 2005.

Le Quéré, C., Rodenbeck, C., Buitenhuis, E. T., et al.: Saturation of the Southern Ocean $\mathrm{CO}_{2}$ sink due to recent climate change, Science, 316, 1735-1738, doi:10.1126/science.1136188, 2007.

Leck, C. and Bigg, E. K.: Source and evolution of the marine aerosol - A new perspective, Geophys. Res. Lett., 32, L19803, doi:10.1029/2005GL023651, 2005.

Leck, C. and Bigg, E. K.: A modified aerosol-cloud-climate feedback hypothesis, Environ. Chem., 4, 400-403, 2007.

Lee, Y. H., Chen, K., and Adams, P. J.: Development of a global model of mineral dust aerosol microphysics, Atmos. Chem. Phys., 9, 2441-2458, 2009,

http://www.atmos-chem-phys.net/9/2441/2009/.

Legrand, M.: Ice-core records of atmospheric sulphur, Phil. Trans. Roy. Soc. B, 352(1350), 241-250, 1997.

Levin, Z., Ganor, E., and Gladstein, V.: The effect of desert particles coated with sulfate on rain formation in the Eastern Mediterranean, J. Appl. Meteorol., 35, 1511-1523, 1996.

Levis S., Wiedinmyer, C., Bonan, G. B., and Guenther, A.: Simulating biogenic volatile organic compound emissions in the Community Climate System Model, J. Geophys. Res., 108, 4659, doi:10.1029/2002JD003203, 2003.

Lewis, E. R. and Schwartz, S. E.: Sea Salt Aerosol Production: Mechanisms, Methods, Measurements, and Models: A Critical Review, American Geophysical Union, Washington, D.C., 2004.

Liao, H. and Seinfeld, J.: Radiative forcing by mineral dust aerosols: sensitivity to key variables, J. Geophys. Res., 103, 31637-31645, 1998.

Liao, H., Adams, P. J., Chung, S. H., Seinfeld, J. H., Mickley, L. J., and Jacob, D. J.: Interactions between tropospheric chemistry and aerosols in a unifed general circulation model, J. Geophys. Res., 108, 4001, doi:10.1029/2001JD001260, 2003.

Liao, H., Chen, W.-T., and Seinfeld, J. H.: Role of climate change in global predictions of future tropospheric ozone and aerosols, J.
Geophys. Res., 111, D12304, doi:10.1029/2005JD006852, 2006.

Lighthart, B. and Sharffer, B. T.: Bacterial flux from chaparral into the atmosphere in the mid-summer at a high desert location, Atmos. Environ., 28, 1267-1274, 1994.

Lindemann, J., Constantinidou, H. A., Barchet, W. R., and Upper, C. D.: Plants as sources of airborne bacteria including ice nucleation active bacteria, Applied Env. Microbiol., 44, 1059-1063, 1982.

Lohmann, U. and Feichter, J.: Global indirect aerosol effects: a review, Atmos. Chem. Phys., 5, 715-737, 2005, http://www.atmos-chem-phys.net/5/715/2005/.

Loreto, F., Pinelli, P., Manes, F., and Kollist, H.: Impact of ozone on monoterpene emissions and evidence for an isoprene-like antioxidant action of monoterpenes emitted by Quercus ilex leaves, Tree Physiol., 24, 361-367, 2004.

Lucas, D. D. and Prinn, R. G.: Sensitivities of gas-phase dimethylsulfide oxidation products to the assumed mechanisms in a chemical transport model, J. Geophys. Res., 110, D21312, doi:10.1029/2004JD005386, 2005.

Mahowald, N. M., Artaxo, P., Baker, A. R., Jickells, T. D., Okin, G. S., Randerson, J. T., and Townsend, A. R.: Impacts of biomass burning emissions and land use change on Amazonian atmospheric phosphorus cycling and deposition, Global Biogeochem. Cy., 19, GB4030, doi:10.1029/2005GB002541, 2005.

Mahowald, N., Jickells, T. D., Baker, A. R., et al.: Global distribution of atmospheric phosphorus sources, concentrations and deposition rates, and anthropogenic impacts, Global Biogeochem. Cy., 22, GB4026, doi:10.1029/2008GB003240, 2008.

Mahowald, N. M. and Luo, C.: A less dusty future?, Geophys. Res. Lett., 30, 1903, doi:10.1029/2003GL017880, 2003.

Mahowald, N. M., Zender, C. S., Luo, C., Savoie, D., Torres, O., and del Corral, J.: Understanding the 30-year Barbados desert dust record, J. Geophys. Res., 107, 4561, doi:10.1029/2002JD002097, 2002.

Mahowald, N. M., Muhs, D. R., Levis, S., Rasch, P. J., Yoshioka, M., Zender, C. S., and Luo, C.: Change in atmospheric mineral aerosols in response to climate: Last glacial period, preindustrial, modern, and doubled carbon dioxide climates, J. Geophys. Res., 111, D10202, doi:10.1029/2005JD006653, 2006.

Manktelow, P. T., Carslaw, K. S., Mann, G. W., and Spracklen, D. V.: The impact of dust on sulfate aerosol, $\mathrm{CN}$ and $\mathrm{CCN}$ during an East Asian dust storm, Atmos. Chem. Phys., 10, 365-382, 2010, http://www.atmos-chem-phys.net/10/365/2010/.

Marlon, J. R., Bartlein, P. J., Carcaillet, C., Gavin, D. G., Harrison, S. P., Higuera, P. E., Joos, F., Power, M. J., and Prentice, I. C.: Climate and human influences on global biomass burning over the past two millennia, Nat. Geosci., 1, 697-702, 2008.

Marticorena, B. and Bergametti, G.: Modeling the atmospheric dust cycle: 1. Design of a soil-derived dust emission scheme, J. Geophys. Res., 100, 16415-16430, 1995.

Martensson, E. M., Nilsson, E. D., de Leeuw, G., Cohen, L. H., and Hansson, H. C.: Laboratory simulations and parameterization of the primary marine aerosol production, J. Geophys. Res., 108, 4297, doi:10.1029/2002JD002263, 2003.

Martin, J. H.: Glacial-interglacial $\mathrm{CO}_{2}$ change: The iron hypothesis, Paleoceanography, 5, 1-13, 1990.

Mbourou, G. N., Bertrand, J. J., and Nicholson, S. E.: The diurnal and seasonal cycles of wind-borne dust over Africa north of the Equator, J. Appl. Meteorol., 36, 868-882, 1997. 
Mencuccini, M., Borghetti, M., Berbigier, P., et al.: The human footprint in the carbon cycle of temperate and boreal forests, Nature, 447, 849-851, doi:10.1038/nature05847, 2007.

Mentel, Th. F., Wildt, J., Kiendler-Scharr, A., Kleist, E., Tillmann, R., Dal Maso, M., Fisseha, R., Hohaus, Th., Spahn, H., Uerlings, R., Wegener, R., Griffiths, P. T., Dinar, E., Rudich, Y., and Wahner, A.: Photochemical production of aerosols from real plant emissions, Atmos. Chem. Phys., 9, 4387-4406, 2009, http://www.atmos-chem-phys.net/9/4387/2009/.

Mercado, L. M., Bellouin, N., Sitch, S., Boucher, O., Huntingford, C., and Cox, P.: Changing contribution of diffuse radiation to the global land carbon sink, Nature, 458, 1014-1018, 2009.

Merikanto, J., Spracklen, D. V., Mann, G. W., Pickering, S. J., and Carslaw, K. S.: Impact of nucleation on global CCN, Atmos. Chem. Phys., 9, 8601-8616, 2009, http://www.atmos-chem-phys.net/9/8601/2009/.

Meskhidze, N., Chameides, W. L., Nenes, A., and Chen, G.: Iron mobilization in mineral dust: Can anthropogenic $\mathrm{SO}_{2}$ emissions affect ocean productivity?, Geophys. Res. Lett., 30, 21, doi:10.1029/2003GL018035, 2003.

Meskhidze, N. and Nenes, A.: Phytoplankton and cloudiness in the southern ocean, Science, 314, 1419-1423, 2006.

Miller, R. L. and Tegen, I.: Climate response to soil dust aerosols, J. Climate, 11, 3247-3267, 1998.

Miller, M. A. and Yuter, S. E.: Lack of correlation between chlorophyll a and cloud droplet effective radius in shallow marine clouds, Geophys. Res. Lett., 35, L13807, doi:10.1029/2008GL034354, 2008.

Mills, M. M., Ridame, C., Davey, M., LaRoche, J., and Geider, R.: Iron and phosphorus co-limit nitrogen fixation in the eastern tropical North Atlantic, Nature, 429, 292-294, 2004.

Morcrette, J.-J., Beljaars, A., Benedetti, A., Jones, L., and Boucher, O.: Sea-salt and dust aerosols in the ECMWF IFS model, Geophys. Res. Lett., 35, L24813, doi:10.1028/2008GL036041, 2008.

Moriondo, M., Good, P., Durao, R., Bindi, M., Giannakopoulos, C., and Corte-Real, J.: Potential impact of climate change on fire risk in the Mediterranean area, Climate Res., 31, 85-95, 2006.

Moulin, C. and Chiapello, I.: Impact of human-induced desertification on the intensification of Sahel dust emission and export over the last decades, Geophys. Res. Lett., 33, L18808, doi:10.1029/2006GL025923, 2006.

Murphy, D. M., Thomson, D. S., and Mahoney, M. J.: In situ measurements of organics, meteoritic material, mercury and other elements in aerosols at 5 to 19 kilometers, Science, 282, 1664 1668, 1998.

Myhre, G. and Stordal, F.: Global sensitivity experiments of the radiative forcing due to mineral aerosols, J. Geophys. Res., 106, 18193-18204, 2001.

Mönkkönen, P., Koponen, I. K., Lehtinen, K. E. J., Uma, R., Srinivasan, D., Hämeri, K., and Kulmala, M.: Death of nucleation and Aitken mode particles: Observations at extreme atmospheric conditions and their theoretical explanation, J. Aerosol Sci. 35, 781-787, 2004

Nepstad, D., Lefebvre, P., Da Silva, U. L., Tomasella, J., Schlesinger, P., Solorzano, L., Moutinho, P., Ray, D., and Benito, J. G.: Amazon drought and its implications for forest flammability and tree growth: a basin-wide analysis, Global Change Biol., 10, 704-717, doi:10.1111/j.1529-8817.2003.00772.x, 2004.

Ng, N. L., Chhabra, P. S., Chan, A. W. H., Surratt, J. D., Kroll, J.
H., Kwan, A. J., McCabe, D. C., Wennberg, P. O., Sorooshian, A., Murphy, S. M., Dalleska, N. F., Flagan, R. C., and Seinfeld, J. H.: Effect of NOx level on secondary organic aerosol (SOA) formation from the photooxidation of terpenes, Atmos. Chem. Phys., 7, 5159-5174, 2007,

http://www.atmos-chem-phys.net/7/5159/2007/.

Niemeyer, T. C., Gillette, D. A., Deluisi, J. J., Kim, Y. J., Niemeyer, W. G., Ley, T., Gill, T. E., and Ono, D.: Optical depth, size distribution and flux of dust from Owen's Lake, California, Earth Surf. Process. Landforms, 24, 463-479, 1999.

Nilsson, E. D., Mårtensson, E. M., Van Ekeren, J. S., de Leeuw, G., Moerman, M., and O'Dowd, C.: Primary marine aerosol emissions: size resolved eddy covariance measurements with estimates of the sea salt and organic carbon fractions, Atmos. Chem. Phys. Discuss., 7, 13345-13400, 2007,

http://www.atmos-chem-phys-discuss.net/7/13345/2007/.

Novakov, T., Corrigan, C. E., Penner, J. E., et al.: Organic aerosols in the Caribbean trade winds: A natural source? J. Geophys. Res., 102, 21307-21313, 1997.

O'Dowd, C. D. and Smith, M. H.: Physicochemical properties of aerosols over the Northeast Atlantic - Evidence for wind-speedrelated submicron sea-salt aerosol production, J. Geophys. Res., 98, 1137-1149, 1993.

O'Dowd, C. D., Facchini, M. C., Cavalli, F., et al.: Biogenically driven organic contribution to marine aerosol, Nature, 431, 676680, doi:10.1038/nature02959, 2004.

O’Dowd, C. D., Jimenez, J. L., Bahreini, R., Flagan, R. C., Seinfeld, J. H., Hämeri, K., Pirjola, L., Kulmala, K., Jennings, S. G., and Hoffmann, T.: Marine aerosol formation from biogenic iodine emissions, Nature, 417, 632-636, 2002.

O’Dowd, C. D., Langmann, B., Varghese, S., Scannell, C., Ceburnis, D., and Facchini, M. C.: A combined organic-inorganic sea-spray source function, Geophys. Res. Lett., 35, L01801, doi:10.1029/2007GL030331, 2008.

O'Dowd, C. D., Aalto, P., Hameri, K., Kulmala, M., and Hoffmann, T.: Atmospheric particles from organic vapours, Nature, 416, 497-497, 2002.

Oman, L., Robock, A., Stenchikov, G. L., and Thordarson, T.: High-latitude eruptions cast shadow over the african monsoon and the flow of the Nile, Geophys. Res. Lett., 33, L18711, doi:10.1029/2006GL027665, 2006.

Palmer, P. I. and Shaw, S. L.: Quantifying global marine isoprene fluxes using MODIS chlorophyll observations, Geophys. Res. Lett., 32, L09805, doi:10.1029/2005GL022592, 2005.

Palmer, P. I., Abbot, D. S., Fu, T. M., and Jacob, D. J.: Quantifying the seasonal and interannual variability of North American isoprene emissions using satellite observations of the formaldehyde column, J. Geophys. Res., 111, D12315, doi:10.1029/2005JD006689, 2006.

Pegoraro, E., Abrell, L., Van Haren, J., Barron-Gafford, G., Grieve, K. A., Malhi, Y., Murthy, R., and Lin, G. H.: The effect of elevated atmospheric $\mathrm{CO}_{2}$ and drought on sources and sinks of isoprene in a temperate and tropical rainforest mesocosm, Glob. Change Biol., 11, 1234-1246, 2005.

Penner, J. E., Andreae, M., Annegarn, H., Barrie, L., Feichter, J., Hegg, D., Jayaraman, A., Leaitch, R., Murphy, D., Nganga, J., and Pitari, G.: Aerosols, their Direct and Indirect Effects, in: Climate Change 2001: The Scientific Basis, Contribution of Working Group I to the Third Assessment Report of the Intergovern- 
mental Panel on Climate Change, edited by: Houghton, J. T., Ding, Y., Griggs, D. J., Noguer, M., van der Linden, P. J., and Xiaosu, D., Cambridge University Press, UK, chapter 5, 289348, 2001.

Petroff, A., Maillet, A., Amielh, M., and Anselmet, F.: Aerosol dry deposition on vegetative canopies. Part I: Review of present knowledge, Atmos. Environ., 42, 3652-3653, 2008.

Pham, M., Boucher, O., and Hauglustaine, D.: Changes in atmospheric sulfur burdens and concentrations and resulting radiative forcings under IPCC SRES emission scenarios for 1990-2100, J. Geophys. Res., 110, D06112, doi:10.1029/2004JD005125, 2005.

Pierce, J. R. and Adams, P. J.: Global evaluation of CCN formation by direct emission of sea salt and growth of ultrafine sea salt, J. Geophys. Res., 111, D06203, doi:10.1029/2005JD006186, 2006.

Pio, C. A., Legrand, M., Oliveira, T., et al.: Climatology of aerosol composition (organic versus inorganic) at nonurban sites on a west-east transect across Europe, J. Geophys. Res., 112, D23S02, doi:10.1029/2006JD008038, 2007.

Polymenakou, P. N., Mandalakis, M., Stephanou, E. G., et al.: Particle size distribution of airborne microorganisms and pathogens during an intense African dust event in the eastern Mediterranean, Environ. Health Persp., 116(3), 292-296, 2008.

Possell, M, Hewitt, C. N., and Beerling, D. J.: The effects of glacial atmospheric $\mathrm{CO}_{2}$ concentrations and climate on isoprene emissions by vascular plants, Global Change Biol., 11, 60-69, 2005.

Posselt, R. and Lohmann, U.: Influence of Giant CCN on warm rain processes in the ECHAM5 GCM, Atmos. Chem. Phys., 8, 37693788, 2008,

http://www.atmos-chem-phys.net/8/3769/2008/.

Prenni, A. J., Petters, M. D. Kreidenweis, S. M., et al.: Wet season ice nuclei budget in the Amazon Basin: Biogenic emissions and Saharan dust, Nature Geosciences, 2, doi:10.1038/NGEO517, 2009.

Price, C. and Rind, D.: The impact of a $2 \times \mathrm{CO}_{2}$ climate on lightning-caused fires, J. Climate, 7, 1484-1494, 1994.

Prospero, J. M. and Lamb, P. J.: African droughts and dust transport to the Caribbean: climate change implications, Science, 302, 1024-1027, 2003.

Prospero, J. M., Ginoux, P., Torres, O., Nicholson, S. E., and Gill, T. E.: Environmental characterization of global sources of atmospheric soil dust identified with the Nimbus 7 Total Ozone Mapping Spectrometer (TOMS) absorbing aerosol product, Rev. Geophys., 40, 1-31, 2002.

Putaud, J. P., Van Dingenen, R., Mangoni, M., et al.: Chemical mass closure and assessment of the origin of the submicron aerosol in the marine boundary layer and the free troposphere at Tenerife during ACE-2, Tellus B, 52, 141-168, 2000.

Quinn, P. K., Bates, T. S., Baum, E., Doubleday, N., Fiore, A. M., Flanner, M., Fridlind, A., Garrett, T. J., Koch, D., Menon, S., Shindell, D., Stohl, A., and Warren, S. G.: Short-lived pollutants in the Arctic: their climate impact and possible mitigation strategies, Atmos. Chem. Phys., 8, 1723-1735, 2008, http://www.atmos-chem-phys.net/8/1723/2008/.

Raes, F.: Entrainment of free tropospheric aerosols as a regulating mechanism for cloud condensation nuclei in the remote marine boundary-layer, J. Geophys. Res., 100, 2893-2903, 1995.

Raisanen, T., Ryyppo, A., and Kellomaki, S.: Effects of elevated $\mathrm{CO}_{2}$ and temperature on monoterpene emission of Scots pine (Pinus sylvestris L.), Atmos. Environ., 42, 4160-4171, 2008.
Randerson, J. T., Liu, H., Flanner, M. G., Chambers, S. D., Jin, Y., Hess, P. G., Pfister, G., Mack, M. C., Treseder, K. K., Welp, L. R., Chapin, F. S., Harden, J. W., Goulden, M. L., Lyons, E., Neff, J. C., Schuur, E. A. G., and Zender, C. S.: The impact of boreal forest fire on climate warming, Science 314, 1130-1132, 2006.

Read, K. A., Mahajan, A. S., Carpenter, L. J., et al.: Extensive halogen-mediated ozone destruction over the tropical Atlantic Ocean, Nature, 453, 1232-1235, 2008.

Robock, A.: Pinatubo eruption: The climatic aftermath, Science, 295, 1242-1244, doi:10.1126/science.1069903, 2002.

Roelofs, G. J.: A GCM study of organic matter in marine aerosol and its potential contribution to cloud drop activation, Atmos. Chem. Phys., 8, 709-719, 2008,

http://www.atmos-chem-phys.net/8/709/2008/.

Rosenfeld, D., Rudich, Y., Lahav, R., et al.: Desert dust suppressing precipitation: A possible desertification feedback loop, P. Natl. Acad. Sci. USA, 98, 5975-5980, 2001.

Rosenstiel, T. N., Potosnak, M. J., Griffin, K. L., Fall, R., and Monson, R. K.: Increased $\mathrm{CO}_{2}$ uncouples growth from isoprene emission in an agriforest ecosystem, Nature, 421, 256-259, 2003.

Running, S. W.: Is global warming causing more, larger wildfires?, Science, 313, 927-928, 2006.

Sanderson, M. G., Jones, C. D., Collins, W. J., Johnson, C. E., and Derwent, R. G.: Effect of climate change on isoprene emissions and surface ozone levels, Geophys. Res. Lett., 30, 1936, doi:10.1029/2003GL017642, 2003.

Schepanski, K., Tegen I., Laurent, B., Heinold, B., and Macke, A.: A new Saharan dust source activation frequency map derived from MSG-SEVIRI IR-channels, Geophys. Res. Lett., 34, L18803, doi:10.1029/2007GL030168, 2007.

Schlesinger, W. H. and Hartley, A. E.: A global budget for atmospheric $\mathrm{NH}_{3}$, Biogeochemistry, 15, 191-211, 1992.

Schultz, M. G., Heil, A., Hoelzemann, J. J., Spessa, A., Thonicke, K., Goldammer, J. G., Held, A. C., Pereira, J. M. C., and van het Bolscher, M.: Global wildland fire emissions from 1960 to 2000, Global Biogeochem. Cy., 22, GB2002, doi:10.1029/2007GB003031, 2008.

Schurgers, G., Arneth, A., Holzinger, R., and Goldstein, A. H.: Process-based modelling of biogenic monoterpene emissions combining production and release from storage, Atmos. Chem. Phys., 9, 3409-3423, 2009, http://www.atmos-chem-phys.net/9/3409/2009/.

Sciare, J., Kanakidou, M., Mihalopoulos, N., et al.: Diurnal and seasonal variation of atmospheric dimethylsulfoxide at Amsterdam Island in the southern Indian Ocean, J. Geophys. Res., 105, 17257-17265, 2000a.

Sciare, J., Mihalopoulos, N., Dentener, F. J., et al.: Interannual variability of atmospheric dimethylsulfide in the southern Indian Ocean, J. Geophys. Res., 105, 26369-26377, 2000 b.

Seinfeld, J. H. and Pandis, S. N.: Atmospheric Chemistry and Physics: From Air Pollution to Climate Change, Wiley, New York, 1998.

Sharkey, T. D., Loreto, F., and Delwiche, C. F.: High-carbon dioxide and sun shade effects on isoprene emission from oak and aspen tree leaves, Plant Cell Environ., 14, 333-338, 1991.

Shaw, G. E.: Bio-controlled thermostasis involving the sulfur cycle, Climatic Change, 5, 297-303, 1983.

Shaw, G. E., Benner, R. L., Cantrell, W., and Clarke, A. D.: The 
regulation of climate: A sulfate particle feedback loop involving deep convection - An editorial essay, Clim. Change, 39, 23-33, 1998.

Shindell, D. T., Faluvegi, G., Bauer, S. E., Koch, D. M., Unger, N., Menon, S., Miller, R. L., Schmidt, G. A., and Streets, D. G.: Climate response to projected changes in shortlived species under an A1B scenario from 2000-2050 in the GISS climate model, J. Geophys. Res., 112, D20103, doi:10.1029/2007JD008753, 2007.

Simo, R. and Pedros-Alio, C.: Role of vertical mixing in controlling the oceanic production of dimethyl sulphide, Nature, 402, 396399, 1999.

Sitch, S., Huntingford, C., Gedney, N., et al.: Evaluation of the terrestrial carbon cycle, future plant geography and climate-carbon cycle feedbacks using five Dynamic Global Vegetation Models (DGVMs), Glob. Change Biol., 14(9), 2015-2039, 2008.

Soden, B. J., Wetherald, R. T., Stenchikov, G. L., and Robock, A.: Global cooling following the eruption of Mt. Pinatubo: A test of climate feedback by water vapor, Science, 296, 727-730, 2002.

Sokolik, I. N. and Toon, O. B.: Direct radiative forcing by anthropogenic airborne mineral aerosols, Nature, 381, 681-683, doi:10.1038/381681a0, 1996.

Sokolik, I. N., Toon, O. B., Bergstrom, R. W., et al.: Modeling the radiative characteristics of airborne mineral dust aerosols at infrared wavelengths, J. Geophys. Res., 103, 8813-8826, 1998.

Spessa, A., Thonicke, K., and Wooster, M.: The importance of fire in the Earth System: Simulation models, EO data and future prospects, Geophys. Res. Abstr., 10, EGU2008-A-02530, 2008.

Son, S. W., Polvani, L. M., Waugh, D. W., Akiyoshi, H., et al.: The impact of stratospheric ozone recovery on the Southern Hemisphere westerly jet, Science, 320, 1486-1489, 2008.

Spracklen, D. V., Pringle, K. J., Carslaw, K. S., Chipperfield, M. P., and Mann, G. W.: A global off-line model of size-resolved aerosol microphysics: I. Model development and prediction of aerosol properties, Atmos. Chem. Phys., 5, 2227-2252, 2005, http://www.atmos-chem-phys.net/5/2227/2005/.

Spracklen, D. V., Carslaw, K. S., Kulmala, M., Kerminen, V.-M., Mann, G. W., and Sihto, S.-L.: The contribution of boundary layer nucleation events to total particle concentrations on regional and global scales, Atmos. Chem. Phys., 6, 5631-5648, 2006,

http://www.atmos-chem-phys.net/6/5631/2006/.

Spracklen, D. V., Logan, J. A., Mickley, L. J., Park, R. J., Yevich, R., Westerling, A. L., and Jaffe, D.: Wildfires drive interannual variability of organic carbon aerosol in the western U.S. in summer, Geophys. Res. Lett., 34, L16816, doi:10.1029/2007GL030037, 2007a.

Spracklen, D. V., Pringle, K. J., Carslaw, K. S., Mann, G. W., Manktelow, P., and Heintzenberg, J.: Evaluation of a global aerosol microphysics model against size-resolved particle statistics in the marine atmosphere, Atmos. Chem. Phys., 7, 2073-2090, 2007b, http://www.atmos-chem-phys.net/7/2073/2007/.

Spracklen, D. V., Carslaw, K. S., Kulmala, M., Kerminen, V.-M., Sihto, S.-L., Riipinen, I., Merikanto, J., Mann, G. W., Chipperfield, M. P., Wiedensohler, A., Birmili, W., and Lihavainen, H.: Contribution of particle formation to global cloud condensation nuclei concentrations, Geophys. Res. Lett. 35, L06808, doi:10.1029/2007GL033038, 2008a.

Spracklen, D. V., Bonn, B., and Carslaw, K. S.: Boreal Forests, Aerosols and the Impacts on Clouds and Climate, Phil. Trans.
Roy. Soc. A., 366, 4613-4626, doi:10.1098/rsta.2008.0201, $2008 b$.

Spracklen, D. V., Arnold, S. R., Sciare, J., Carslaw, K. S., and Pio, C.: Globally significant oceanic source of organic carbon aerosol, Geophys. Res. Lett., 35 , L12811,doi:10.1029/2008GL033359, 2008c.

Spracklen, D. V., Mickley, L. J., Logan, J. A., Hudman, R. C., Yevich, R., Flannigan, M. D., and Westerling, A. L.: Impacts of climate change from 2000 to 2050 on wildfire activity and carbonaceous aerosol concentrations in the western United States, J. Geophys. Res., 114, D20301, doi:10.1029/2008JD010966, 2009.

Stefels, J., Steinke, M., Turner, S., et al.: Environmental constraints on the production and removal of the climatically active gas dimethylsulphide (DMS) and implications for ecosystem modelling, Biogeochemistry, 83, 245-275, 2007.

Stier, P., Feichter, J., Kinne, S., Kloster, S., Vignati, E., Wilson, J., Ganzeveld, L., Tegen, I., Werner, M., Balkanski, Y., Schulz, M., Boucher, O., Minikin, A., and Petzold, A.: The aerosolclimate model ECHAM5-HAM, Atmos. Chem. Phys., 5, 11251156, 2005, http://www.atmos-chem-phys.net/5/1125/2005/.

Stocks, B., Fosberg, M., Lynham, T., Mearns, L., Wotton, B., Yang, Q., Jin, J., Lawrence, K., Hartley, G., Mason, J., and McKenney, D.: Climate change and forest fire potential in Russian and Canadian boreal forests, Clim. Change, 38, 1-13, 1998.

Sunda, W., Kieber, D. J, Kiene, R. P., et al.: An antioxidant function for DMSP and DMS in marine algae, Nature, 418, 317-320, 2002.

Swap, R., Garstang, M., Greco, S., Talbot., R., and Kallberg, P.: Saharan dust in the Amazon basin, Tellus B, 44(2) 133-149, 1992.

Tagaris, E., Liao, K.-J., Manomaiphiboon, K., Woo, J.-H., He, S., Amar, P., and Russell, A. G.: Impacts of future climate change and emissions reductions on nitrogen and sulfur deposition over the United States, Geophys. Res. Lett., 35, L08811, doi:10.1029/2008GL033477, 2008.

Tegen, I. and Fung, I.: Contribution to the atmospheric mineral aerosol load from land surface modification, J. Geophys. Res., 100, 18707-18726, 1995.

Tegen, I., Lacis, A. A., and Fung, I.: The influence on climate forcing of mineral aerosols from disturbed soils, Nature, 380, 419 422, doi:10.1038/380419a0, 1996.

Tegen, I., Harrison, S. P., Kohfeld, K., Prentice, I. C., Coe, M., and Heimann, M.: Impact of vegetation and preferential source areas on global dust aerosol: Results from a model study, J. Geophys. Res., 107, 4576, doi:10.1029/2001JD000963, 2002.

Tegen, I., Werner, M., Harrison, S. P., and Kohfeld, K. E.: Relative importance of climate and land use in determining present and future global soil dust emission, Geophys. Res. Lett., 31, L05105, doi:10.1029/2003GL019216, 2004.

Thordarson, T. and Larsen, G.: Volcanism in Iceland in historical time: Volcano types, eruption styles and eruptive history, J. Geodynamics, 43, 118-152, 2007.

Thordarson, T. and Self, S.: Atmospheric and environmental effects of the 1783-1784 Laki eruption: A review and reassessment, J. Geophys. Res., 108, 4011, doi:10.1029/2001JD002042, 2003.

Todd, M. C., Washington, R., Martins, J. V., Dubovnik, O., Lizcano, G., M'Bainayel, S., and Engelstaedter, S.: Mineral dust emission from the Bodele Depression, northern Chad, during BoDEx, J. Geophys. Res., 112, D06207, doi:10.1029/2006JD007170, 2007. 
Tsigaridis, K. and Kanakidou, M.: Secondary organic aerosol importance in the future atmosphere, Atmos. Environ., 41(22), 4682-4692, 2007.

Tsigaridis, K., Lathière, J., Kanakidou, M., and Hauglustaine, D. A.: Naturally driven variability in the global secondary organic aerosol over a decade, Atmos. Chem. Phys., 5, 1891-1904, 2005, http://www.atmos-chem-phys.net/5/1891/2005/.

Tunved, P., Hansson, H. C., Kerminen, V. M., Strom, J., Dal Maso, M., Lihavainen, H., Viisanen, Y., Aalto, P. P., Komppula, M., and Kulmala, M.: High natural aerosol loading over boreal forests, Science, 312(5771), 261-263, 2006a.

Tunved, P., Korhonen, H., Strom, J., Hansson, H. C., Lehtinen, K. E. J., and Kulmala, M.: Is nucleation capable of explaining observed aerosol integral number increase during southerly transport over Scandinavia?, Tellus B, 58, 129-140, 2006b.

Tunved, P., Ström, J., Kulmala, M., Kerminen, V.-M., Dal Maso, M., Svenningson, B., Lunder, C., and Hansson, H.C.: The natural aerosol over Northern Europe and its relation to anthropogenic emissions - Implications of important climate feedbacks, Tellus B, 60, 473-484, doi:10.1111/j.16000889.2008.00363.x, 2008.

Turner, D. P., Baglio, J. V., Wones, A. G., and Pross, D.: Climate change and isoprene emission from vegetation, Chemosphere, 23(1), 37-56, 1991.

Underwood, G. M., Song, C. H., Phadnis, M., Carmichael, G. R., and Grassian, V. H.: Heterogeneous reactions of $\mathrm{NO}_{2}$ and $\mathrm{HNO}_{3}$ on oxides and mineral dust: A combined laboratory and modelling study, J. Geophys. Res., 106, 18055-18066, 2001.

Usher, C. R., Al-Hosney, H., Carlos-Cuellar, S., and Grassian, V. H.: A laboratory study of the heterogeneous uptake and oxidation of sulfur dioxide on mineral dust particles, J. Geophys. Res., 107, 4713, doi:10.1029/2002JD002051, 2002.

Vaattovaara, P., Huttunen, P. E., Yoon, Y. J., Joutsensaari, J., Lehtinen, K. E. J., O'Dowd, C. D., and Laaksonen, A.: The composition of nucleation and Aitken modes particles during coastal nucleation events: evidence for marine secondary organic contribution, Atmos. Chem. Phys., 6, 4601-4616, 2006,

http://www.atmos-chem-phys.net/6/4601/2006/.

Valdes, P. J., Beerling, D. J., and Johnson, C. E.: The ice age methane budget, Geophys. Res. Lett., 32, L02704, doi:10.1029/2004GL021004, 2005.

Vallina, S. M. and Simo, R.: Re-visiting the CLAW hypothesis, Environ. Chem., 4, 384-387, 2007a.

Vallina, S. M. and Simo, R.: Strong relationship between DMS and the solar radiation dose over the global surface ocean, Science, 315, 506-508, 2007b.

Vallina, S. M., Simó, R., and Gassó, S.: What controls CCN seasonality in the Southern Ocean? A statistical analysis based on satellite-derived chlorophyll and CCN and model-estimated $\mathrm{OH}$ radical and rainfall, Global Biogeochem. Cy., 20, GB1014, doi:10.1029/2005GB002597, 2006.

Vallina, S. M., Simó, R., Gassó, S., de Boyer-Montégut, C., del Río, E., Jurado, E., and Dachs, J.: Analysis of a potential "solar radiation dose-dimethylsulfide-cloud condensation nuclei" link from globally mapped seasonal correlations, Global Biogeochem. Сy., 21, GB2004, doi:10.1029/2006GB002787, 2007a.

Vallina, S. M., Simo, R., and Manizza, M.: Weak response of oceanic dimethylsulfide to upper mixing shoaling induced by global warming, Proc. Natl. Acad. Sci. USA, 104, 16004-16009,
$2007 b$.

Vallina, S. M., Simo, R., Anderson, T. R., Gabric, A., Cropp, R., and Pacheco, J. M.: A dynamic model of oceanic sulfur (DMOS) applied to the Sargasso Sea: Simulating the dimethylsulfide (DMS) summer paradox, J. Geophys. Res., 113, G01009, doi:10.1029/2007JG000415, 2008.

van der Werf, G. R., Randerson, J. T., Giglio, L., Gobron, N., and Dolman, A. J.: Climate controls on the variability of fires in the tropics and subtropics, Global Biogeochem. Cy., 22, GB3028, doi:10.1029/2007GB003122, 2008.

van der Werf, G. R., Randerson, J. T., Collatz, G. J., Giglio, L., Kasibhatla, P. S., Arellano, A. F., Olsen, S. C., and Kasischke, E. S.: Continental-scale partitioning of fire emissions during the 1997 to $2001 \mathrm{El} \mathrm{Nino/La} \mathrm{Nina} \mathrm{period,} \mathrm{Science,} \mathrm{303,} \mathrm{73-76,} 2004$.

Velikova, V., Pinelli, P., Pasqualini, S., Reale, L., Ferranti, F., and Loreto, F.: Isoprene decreases the concentration of nitric oxide in leaves exposed to elevated ozone, New Phytol., 166, 634, 419426, 2005.

Verheggen, B., Simo, R., Anderson, T. R., Gabric, A., et al.: alphaPinene oxidation in the presence of seed aerosol: Estimates of nucleation rates, growth rates, and yield, Environ. Sci. Technol., 41(17), 6046-6051, 2007.

Vogt, M., Steinke, M., Turner, S., Paulino, A., Meyerhöfer, M., Riebesell, U., LeQuéré, C., and Liss, P.: Dynamics of dimethylsulphoniopropionate and dimethylsulphide under different $\mathrm{CO}_{2}$ concentrations during a mesocosm experiment, Biogeosciences, 5, 407-419, 2008, http://www.biogeosciences.net/5/407/2008/.

Volkamer, R., Jimenez, J. L., San Martini, F., Dzepina, K., Zhang, Q., Salcedo, D., Molina, L. T., Worsnop, D. R., and Molina, M. J.: Secondary organic aerosol formation from anthropogenic air pollution: Rapid and higher than expected, Geophys. Res. Lett., 33, L17811, doi:10.1029/2006GL026899, 2006.

von Glasow, R.: A look at the CLAW hypothesis from an atmospheric chemistry point of view, Environ. Chem., 4, 379-381, 2007.

Warneck, P.: Chemistry of the Natural Atmosphere, 2nd edn., Academic Press, San Diego, California, 2000.

Washington, R., Todd, M., Middleton, N. J., and Goudie, A. S.: Dust-storm source areas determined by the total ozone monitoring spectrometer and surface observations, Ann. Assoc. Amer. Geog., 93, 297-313, 2003.

Washington, R., Todd, M. C., Lizcano, G., et al.: Links between topography, wind, deflation, lakes and dust: The case of the Bodele Depression, Chad, Geophys. Res. Lett., 33, L09401, doi:10.1029/2006GL025827, 2006.

Warren, S. G. and Wiscombe, W. J.: A model for the spectral albedo of snow. II: Snow containing atmospheric aerosols, J. Atmos. Sci., 37, 2734-2745, 1980.

Weisenstein, D., Bekki, S., Mills, M., Pitari, G., and Timmreck, C.: Modeling of stratospheric aerosols, in: Assessment of Stratospheric Aerosol Properties (ASAP), SPARC Report No. 4 WMO/TD- No. 1295, 219-272, 2006.

Westerling, A. L., Hidalgo, H. G., Cayan, D. R., and Swetnam, T. W.: Warming and earlier spring increase Western U.S. forest wildfire activity, Science, 313, 943, doi:10.1126/science.1128834, 2006.

Westerling, A. and Bryant, B.: Climate change and wild fire in California, Climatic Change, 87, S231-S249, 2008. 
Wiedinmyer, C., Tie, X., Guenther, A., Neilson, R., and Granier, C.: Future changes in biogenic isoprene emissons: How might they affect regional and global atmospheric chemistry, Earth Interactions, 10, 1-19, 2006.

Wingenter, O. W., Haase, K. B., Zeigler, M., et al.: Unexpected consequences of increasing $\mathrm{CO}_{2}$ and ocean acidity on marine production of DMS and CH2CII: Potential climate impacts, Geophys. Res. Lett., 34, L05710, doi:10.1029/2006GL028139, 2007.

Winiwarter, W., Bauer, H., Caseiro, A., et al.: Quantifying emissions of primary biological aerosol particle mass in Europe, Atmos. Environ., 43(7), doi:10.1016/j.atmosenv.2008.01.037, 2009.

Woodward, S.: Modeling the atmospheric life cycle and radiative impact of mineral dust in the Hadley Centre climate model, J. Geophys. Res., 106, 18155-18166, 2001.

Woodward, S., Roberts, D. L., and Betts, R. A.: A simulation of the effect of climate change-induced desertification on mineral dust aerosol, Geophys. Res. Lett., 32, L18810, doi:10.1029/2005GL023482, 2005.

Woodhouse, M. T., Mann, G. W., Carslaw, K. S., and Boucher, O.: New Directions: The impact of oceanic iron fertilization on cloud condensation nuclei, Atmos. Environ., 42, 5728-5730, 2008.

Woodhouse, M. T., Carslaw, K. S., Mann, G. W., Vallina, S. M., Vogt, M., Halloran, P. R., and Boucher, O.: Low sensitivity of cloud condensation nuclei to changes in the sea-air flux of dimethyl-sulphide, Atmos. Chem. Phys. Discuss., 10, 37173754, 2010,

http://www.atmos-chem-phys-discuss.net/10/3717/2010/.

Wotton, B. and Flannigan, M.: Length of the fire season in a changing climate, Forest. Chron., 69, 187-192, 1993.
Wu, J., Rember, R., and Cahill, C.: Dissolution of aerosol iron in the surface waters of the North Pacific and North Atlantic oceans as determined by a semicontinuous flowthrough reactor method, Global Biogeochem. Cy., 21, GB4010, doi:10.1029/2006GB002851, 2007.

Wu, S., Mickley, L. J., Leibensperger, E. M., Jacob, D. J., Rind, D., and Streets, D. G.: Effects of 2000-2050 global change on ozone air quality in the United States, J. Geophys. Res., 113, D06302, doi:10.1029/2007JD008917, 2008.

Yassaa, N., Peeken, I., Zollner, E., Bluhm, K., Arnold, S., Spracklen, D., and Williams, J.: Evidence for marine production of monoterpenes, Environ. Chem., 5, 391-401, 2008.

Zender, C. S., Newman, D., and Torres, O.: Spatial heterogeneity in aeolian erodibility: uniform, topographic, geomorphic and hydrologic hypotheses, J. Geophys. Res., 108, 4543, doi:10.1029/2002JD003039, 2003.

Zhang, Q., Jimenez, J. L., Canagaratna, M. R., et al.: Ubiquity and dominance of oxygenated species in organic aerosols in anthropogenically influenced Northern Hemisphere midlatitudes, Geophys. Res. Lett., 34, L13801, doi:10.1029/2007GL029979, 2007a.

Zhang, H., McFarquhar, G. M., Saleeby, S. M., and Cotton, W. R.: Impacts of Saharan dust as CCN on the evolution of an idealized tropical cyclone, Geophys. Res. Lett., 34, L14812, doi:10.1029/2007GL029876, 2007b.

Zhang, R. Y., Suh, I., Zhao, J., et al.: Atmospheric new particle formation enhanced by organic acids, Science, 304, 1487-1490, doi:10.1126/science.1095139, 2004.

Zoppas, B., Valencia-Barrera, R. M., Duso, S. M. V., et al.: Fungal spores prevalent in the aerosol of the city of Caxias do Sul, Rio Grande do Sul, Brazil, over a 2-year period (2001-2002), Aerobiologia, 22, 119-126, 2006. 